\title{
History of EMerald MiNING IN THE Habachtal Deposit of Austria, Part I
}

Karl Schmetzer

The sources of emeralds used in Roman jewelry as well as jeweled pieces (including crowns and book covers) dating from antiquity to the Middle Ages and before the discovery of the Colombian emerald deposits in the sixteenth century remain an ongoing matter of controversy. Two potential localities dominate the discussion: the mines in the Eastern Desert of Egypt and the Habachtal deposit in Austria. The first published reference to the Habachtal emerald occurrence dates to 1797. The majority of publications from the nineteenth and twentieth centuries agree that Samuel Goldschmidt, a jeweler from Vienna, purchased the mountain area in which the Habachtal emerald occurrence is located and commenced mining soon thereafter, in the early 1860s. A later period from the mid-1890s to about 1914 is frequently mentioned, in which the mine was owned and worked by an English company. However, further details regarding both periods and the various transitions of ownership and further circumstances of emerald mining before World War I are rarely given and often are not consistent, and activities in the times before the 1860s and between 1870 and 1890 are obscure. Using a wide selection of materials from Austrian and German archives, largely unpublished, the author seeks to trace the history of the Habachtal mine through several centuries and to fill gaps left by existing publications.

$\mathrm{t}$ is established that emeralds were mined during the Ptolemaic, Roman, Byzantine, and Islamic eras in Egypt's Eastern Desert, in the Wadi Sikait and Gebel Zabara regions. ${ }^{1}$ Far less certainty exists with respect to emeralds from the Habachtal deposit, located in the Pinzgau region of Salzburg Federal State, Austria (figure 1). Similar to the Egyptian deposits, it has been speculated that the emerald deposit in Habachtal might have been known to the Celts and Romans, ${ }^{2}$ with some even going so far as to suggest that the deposit had been exploited and mined by the Romans. ${ }^{3}$ Absent, however, is any written document or clear archaeological evidence to verify a link to the Romans or Celts. ${ }^{4}$ Nor do the few studies aiming to establish an empirical link between emeralds in historical jewelry and recently mined stones from Habachtal (through trace element determination, inclusion study, and other approaches) offer any conclusive support. ${ }^{5}$ The problem is due to the fact that a clear distinction between emeralds from the different mining regions in Egypt and Habachtal has not yet been worked out in the few existing studies. For the Middle Ages, the famous Saint Louis emerald of

See end of article for About the Author.

Gems \& Gemology, Vol. 57, No. 4, pp. 338-371,

http://dx.doi.org/10.5741/GEMS.57.4.338

(C) 2021 Gemological Institute of America the crown of France was assigned to the Habachtal occurrence using oxygen isotopic composition values. ${ }^{6}$ Furthermore, several references (see, e.g., the Early Evidence of Mining section later in this article) indicate emerald mining in Austria from the sixteenth to eighteenth centuries.

The present paper aims to contribute to the mining history of emeralds in Habachtal and first to evaluate the sources referring to the period from the sixteenth to eighteenth centuries, which would-according to the present knowledge-indicate early published accounts of the mining of Habachtal emeralds. Furthermore, a chronicle of emerald collection, mining activities, and ownership up to World War I is given, starting with the first known mention of the emerald location in Habachtal in a scientific journal by K.M. Schroll ${ }^{7}$ at the end of the eighteenth century and the beginning of mining operations in the early 1860s by Samuel Goldschmidt, followed by an English company in 1895 . The people in the background,

\footnotetext{
'Shaw et al., 1999; Rivard et al., 2002.

${ }^{2}$ See Ward, 1993; Gonthier, 1998.

${ }^{3}$ Giuliani et al., 2000.

${ }^{4}$ Ertl, 1982; Grundmann, 1991; Grundmann and Koller, 2003.

${ }^{5}$ See Calligaro et al., 2000; Kržic et al., 2013.

${ }^{6}$ Giuliani et al., 2000; Stehrer, 2000.

${ }^{7}$ Schroll, 1797.
} 

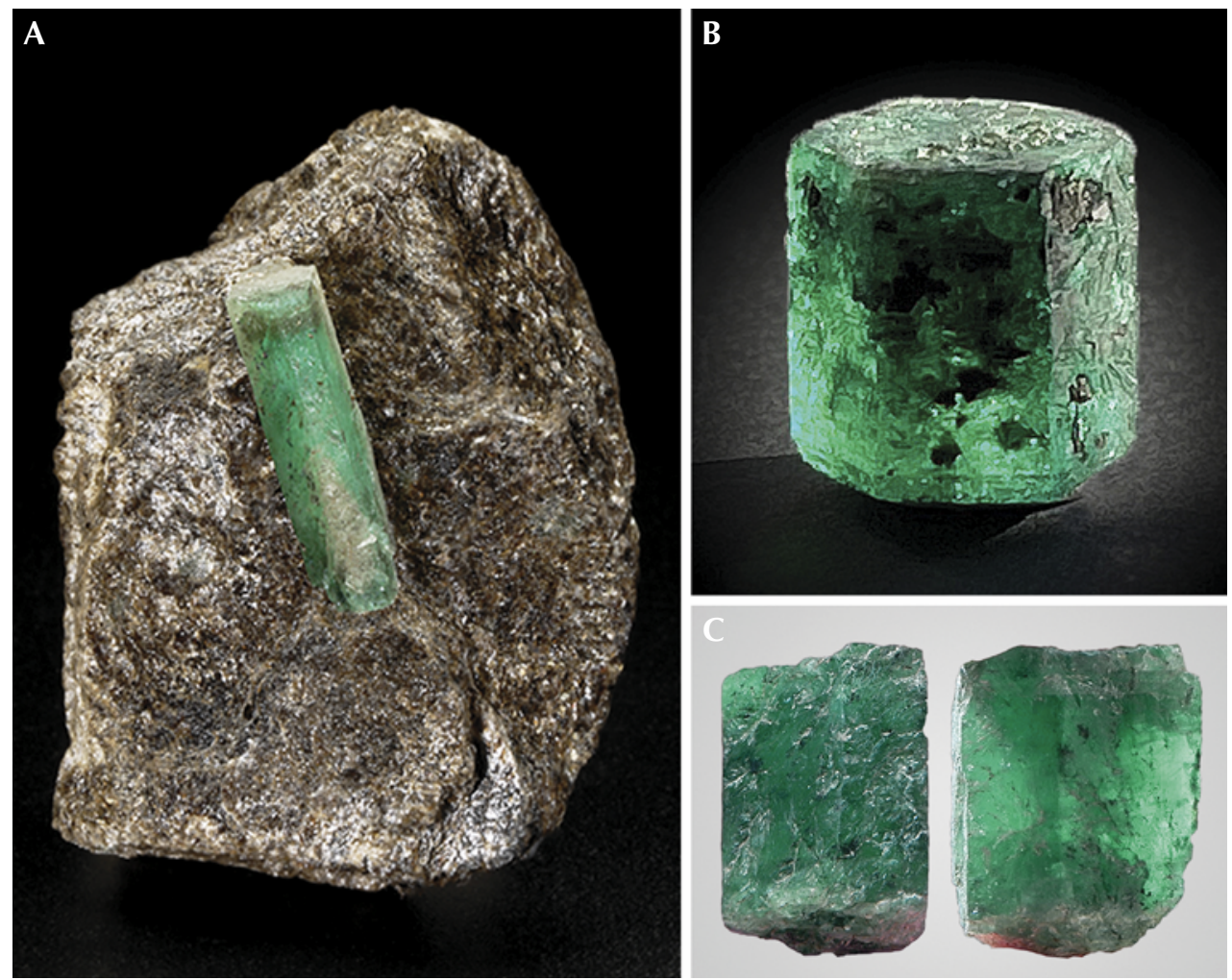

Figure 1. A: Emerald crystal from Habachtal, 2.0 $\mathrm{cm}$ in length, on a matrix of biotite schist. Photo by G. Martayan; private collection. B: Emerald crystal from Habachtal, 12 $\mathrm{mm}$ in length and weighing $15 \mathrm{ct}$, found in 1972 and displaying extraordinary quality. Photo by Tobias Weise; collection of Christian Weise. C: Emerald crystal from Habachtal, $4.5 \mathrm{~cm}$ in length and weighing 128 $c t$, found in the mid1970s, one of the largest of gem quality discovered at the locality in the twentieth century. Shown in reflected light (left) and transmitted light (right); courtesy of Kristallmuseum Riedenburg.

controlling the English firm within two different working periods, have not been identified. Conflicts with the Austrian administration and other problems, which caused a first group of English owners

\section{In Brief}

- The Habachtal emerald occurrence in Austria was initially known as a secondary deposit, first described in 1797. The primary emerald source was discovered some decades later, in the 1820 s.

- Prior to the late eighteenth century, single stones may have been found on occasion, but there is no verifiable evidence of formal mining activities.

- Open-pit and underground mining were first performed by Samuel Goldschmidt for a few years in the early 1860 s.

- Ownership of the Habachtal property was transferred to the English firm Emerald Mines Limited in 1896 and remained under that entity until 1913 . Two periods within that interval saw underground mining, under the control of different English individuals, before ownership reverted to Austrian citizens in 1914.

of the property to sell the firm in 1906 and a second group of English owners to fail completely in emerald recovery, are also presented.

\section{THE HABACHTAL LOCALITY}

The Habachtal (meaning Habach Valley), through which Habach Creek runs, lies within a network of valleys in a mountainous region known as the Großvenediger [Great Venetian] area, named after the Großvenediger peak (3662 m) located to the south. A series of five such parallel valleys containing eponymous creeks flowing essentially south-north all lead toward the larger Salzach River, flowing west-east in the Salzach Valley (figure 2). The Habach Valley is flanked on the west by the Untersulzbach and Obersulzbach Valleys and on the east by the Hollersbach and Felber Valleys. The two larger municipalities in the Salzach region are Neukirchen (to the west of Habach Valley) and Bramberg (to the east).

Historically, extensive mining activities have been reported for the Pinzgau region. In the Untersulzbach and Hollersbach Valleys, notable copper mining has been documented since the early sixteenth century. Lead- and zinc-bearing ores have also been mined to a lesser extent. In the Habach Valley, mining mainly for lead and silver has frequently been reported over the course of many centuries. ${ }^{8}$

${ }^{8}$ Schroll, 1792, 1799; Pillwein, 1839; von Kürsinger, 1841; Ritter von Köchel, 1859; Fugger, 1881; Lahnsteiner, 1980; Gruber and Ludwig, 1982; Hönigschmid, 1993; Feitzinger et al., 1998; Lewandowski, 2008; Seifriedsberger, 2008. 


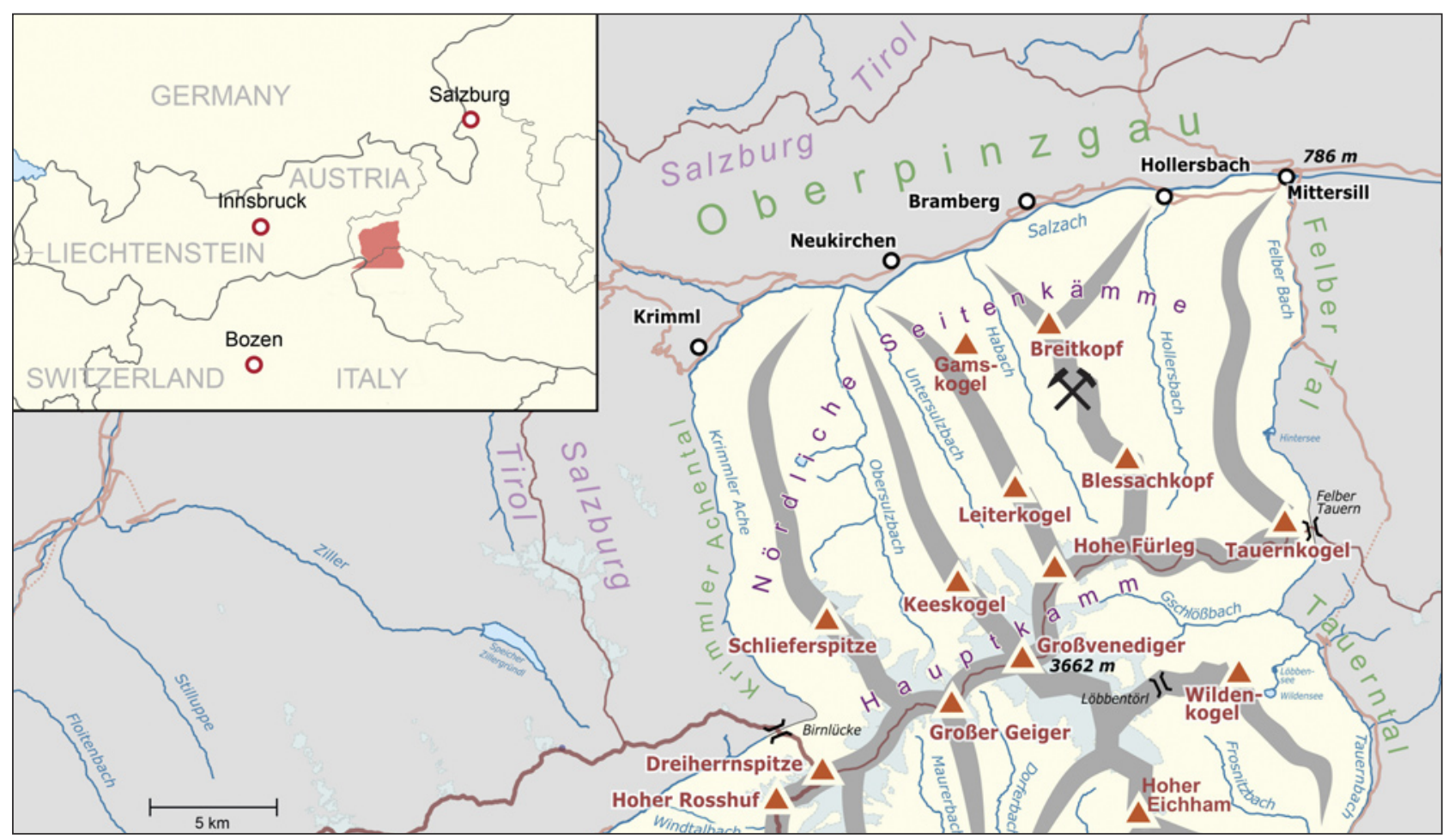

Figure 2. Map of a portion of the Oberpinzgau (the western part of the Pinzgau region) where the Habachtal (Habach Valley) is located. Habach Creek flows through the valley, and the Habachtal emerald mine is located on the eastern flanks of the valley; additional valleys with their eponymous creeks are to the east and west. Mountain ridges are shown in gray, and the hammer and pick symbol indicates the emerald mine. Modified after Pechristener, Austria location map, Open Database.

The Habachtal emerald mine is located on the eastern flanks of the valley, approximately $70 \mathrm{~km}$ east of Innsbruck, the capital of Tyrol, Austria. The main emerald-bearing host rocks in the occurrence are biotite-, actinolite-, tremolite-, and talc-schists, or mixtures thereof (see again figure 1). ${ }^{9}$ In addition to green emeralds, gray to blue beryls (aquamarines) are also found, while other beryllium minerals such as phenakite or chrysoberyl are rare. Occasionally, beryl and emerald crystals are discovered together in the matrix, but zoned crystals consisting of gray or bluish aquamarine and emerald are extremely unusual. Four mining galleries exist today at an elevation between 2,100 and 2,200 $\mathrm{m}$ above sea level, and on the surface of the hill, emerald-bearing solid rocks (e.g., biotite schist) are found sporadically.

\section{EARLY EVIDENCE OF MINING}

In determining the earliest written evidence of Habachtal emerald mining, contemporary thinking tends to look in one or more of three general directions. To find early references, the author contacted the people involved at present in Habachtal emerald mining and the local Bramberg Museum's staff respon- sible for the mineral collection. The author was informed ${ }^{10}$ of a reference describing the destruction of the Habachtal emerald mines prior to 1600 , which could confirm emerald mining in the sixteenth century. The reference in question turned out to be a publication by Herbert Aulitzky. ${ }^{11}$ Other views center on material resulting from a 1669 journey by the DanishItalian scientist Niels Stensen (figure 3). ${ }^{12}$ Yet another series of works cites a 1727 mining chronicle as the oldest description, which has now been identified by

\footnotetext{
${ }^{9}$ Grundmann, 1991.

${ }^{10}$ A. Steiner, pers. comm., 2019; E. Steinberger, pers. comm., 2019.

${ }^{11}$ Aulitzky, 1973. Herbert Aulitzky (1922-2012) was a professor at the Institut für Wildbach- und Lawinenverbauung, Universität für Bodenkultur in Vienna.

${ }^{12}$ Niels Stensen (1638-1686), also known as Nicolaus Steno, studied medicine in Copenhagen, publishing on topics involving anatomy and medicine, before dedicating his interest to the fields of paleontology, stratigraphy, and crystallography. From 1666 to 1672, Stensen worked in Florence under the Grand Dukes of Tuscany Ferdinand II and Cosimo III de' Medici. His principal work on earth sciences, Prodromus on Solids, published in 1669 in Florence, is considered the beginning of modern stratigraphy and geology. In 1675, Stensen renounced his scientific career and was ordained a Catholic priest, becoming a bishop in 1677. Scherz, 1987; Hansen, 2009; Hauschke, 2019.
} 


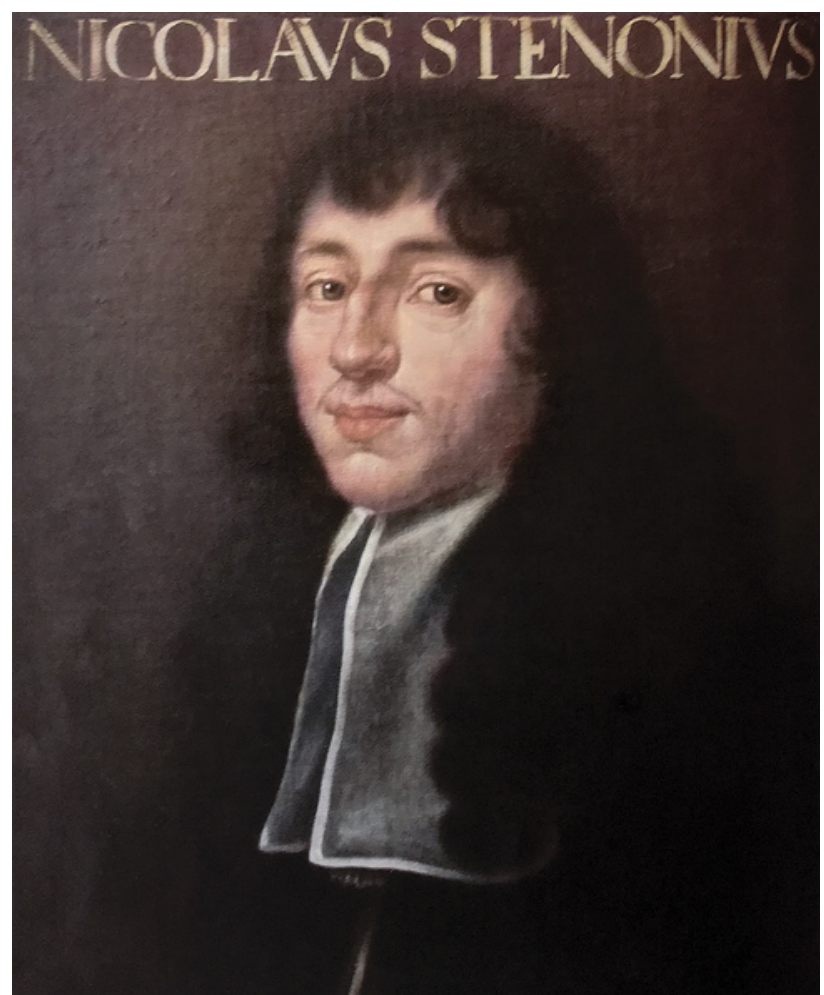

Figure 3. Portrait of Niels Stensen (Nicolaus Steno or Nicolaus Stenonius), likely painted circa 1670 in Florence, when Stensen was in his early thirties. Uffizi Gallery, Florence.

the present author as the voluminous treatise by Franz Ernst Brückmann (1697-1753; figure 4), a medical doctor and scientist. Beyond such written references, a fourth piece of early evidence comes in the form of oral traditions that have long assumed that particular emeralds must have come from Habachtal. All four approaches, despite having been accepted uncritically and without further evaluation for decades, fall short of establishing any formal mining at Habachtal.

The Aulitzky Reference and the Possibility of Late Sixteenth-Century Emerald Mining at Habachtal. The work by Aulitzky listed and described natural disasters (translated from German): "The mines in the Tauern region, which were still active in this period [end of the sixteenth century, after 1572], were threatened by torrents. In 1593, the structures and buildings of the emerald mine in the Habachtal were completely damaged." 13 Although Aulitzky cited no supporting reference, the basis would appear to be a text by Jos. Lorenz discussing the effects of landslides and water from the Habach Creek and commenting (also translated from German): "The slopes of this valley frequently create huge landslides. In 1593, one of these

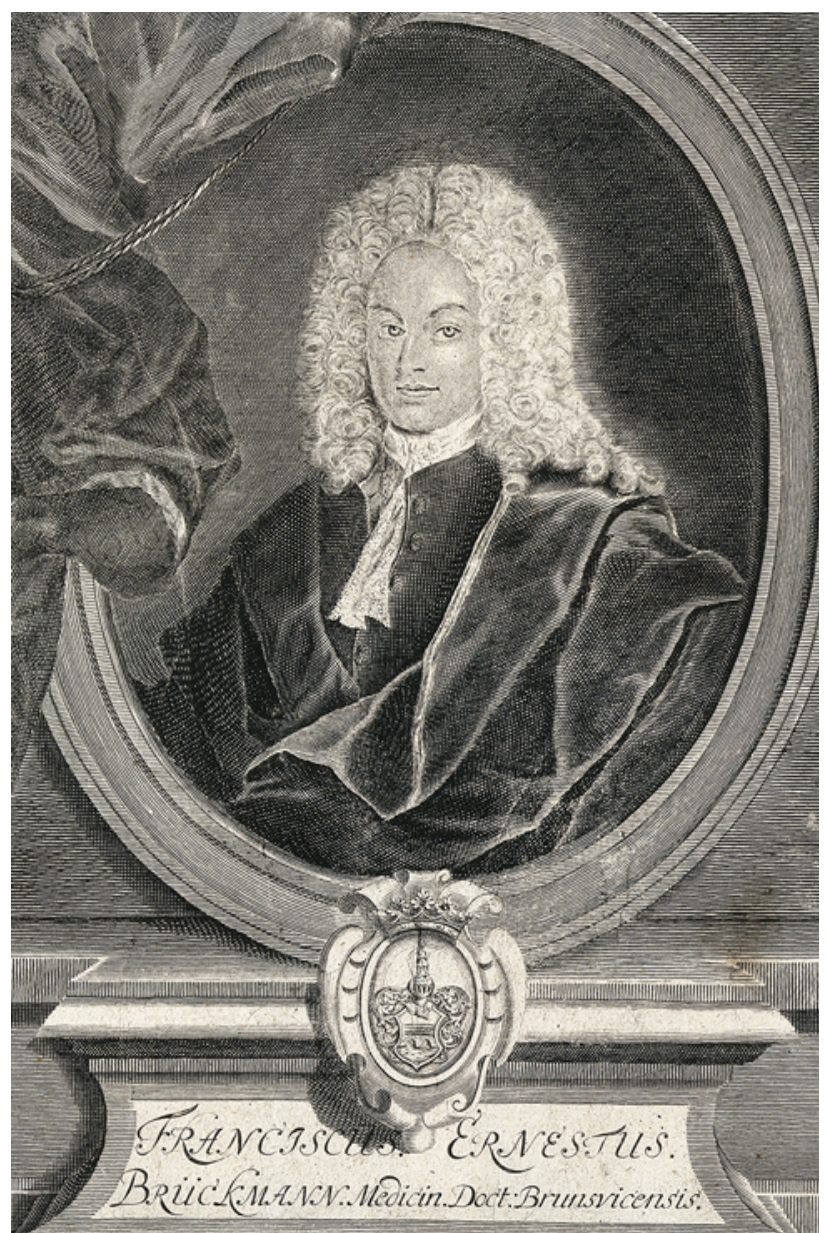

Figure 4. In a mining chronicle published in Braunschweig in 1727, the medical doctor and scientist Franz Ernst Brückmann referred to "emeralds" from the village of Bach in Bavaria, which has repeatedly been misinterpreted as a description of emeralds from the Habach Valley. The "emeralds" from Bach, however, have since been identified as green fluorites. This copper engraving by E.L. Creite was published in the 1727 mining chronicle.

landslides damaged the structures and buildings of the existing mines."14

Lorenz's generic reference merely to mines thus offers no proof of emerald mines, a misapplication borne out by descriptions of the same 1593 event detailing that destructive landslides covered the entrances of tunnels to silver mines in the Gamskogel area but making no mention of emerald mines. ${ }^{15}$ As

\footnotetext{
${ }^{13}$ Aulitzky, 1973

${ }^{14}$ Lorenz, 1857.

${ }^{15}$ See Reisigl, 1786; Vierthaler, 1816; von Kürsinger, 1841; Wallmann 1870; Lehmann, 1879; Stiny, 1938; Lahnsteiner, 1980; Rohr, 2007; Seifriedsberger, 2007.
} 
tence of emerald mines at Habachtal. There is, nonetheless, general agreement that Habachtal was the locality signified. This conclusion is further buttressed by a catalog of rocks, minerals, and fossils prepared by Stensen circa 1671-1672 in Florence. Titled Indice di cose naturali, it listed samples in the Grand Duke's collection, some of them collected by Stensen himself. Items 259 to 304 primarily represented samples collected from 1669 to 1670 during his European journey, some explicitly from Tyrol. ${ }^{19}$ Item 279 described a collection of various crystals, including quartz, emeralds, amethysts, and garnets, thus implying that Stensen might have been able to obtain emeralds from the Habachtal occurrence during the trip.

The Mining Chronicle by Brückmann (1727). In the third commonly cited reference, the 1727 mining chronicle, Brückmann collected information about more than 1,600 mines worldwide, mainly from the literature. ${ }^{20}$ The portion describing the Prince-Archbishopric of Salzburg made no mention of emeralds. Conversely, the section dealing with Bavaria included the following entries (translated from German):

- Donaustauff [referring to the modern municipality of Donaustauf], 2 miles from Regenspurg [the modern city of Regensburg], here great quantities of occidental amethysts and emeralds are mined.

- Bach, a village, nearby green emeralds and blue amethysts are mined.

A revised and more detailed version published in 1730 after samples had been obtained from the locality repeated the foregoing entries and added that Brückmann could not find any special properties of these materials, that they were fragile, and that it would be extremely difficult to cut and polish samples from the occurrence. ${ }^{21}$

\footnotetext{
${ }^{19}$ Scherz, 1956, 1958.

${ }^{20}$ Brückmann, 1727.

${ }^{21}$ Brückmann, 1730 (with identical title but designated part II).

22Pichler, 1865; Freed, 1999; Dopsch and Lang, 2012.

${ }^{23}$ Lehner, 1669, 1702, 1718; Fürnohr, 1952.

${ }^{24}$ Viernstein, 1987; Jacob, 2006.

${ }^{25}$ Flurl, 1792.

${ }^{26}$ Mineralienatlas - Fossilienatlas, Grube Kittenrain (Schönfärbiges Bergwerk), https://www.mineralienatlas.de/lexikon/index.php/Deutschland/ Bayern/Oberpfalz\%2C\%20Bezirk/Regensburg\%2C\%20Landkreis/ Donaustaufer\%20Revier/Grube $\% 20$ Kittenrain\%20\%28Sch\%C3\% B6nf $\%$ C3\%A4rbiges $\% 20$ Bergwerk $\% 29$

${ }^{27}$ Scherz, 1955.
}

From this information, it becomes extremely unlikely that Habachtal could be the place under discussion. From a geographical perspective, the Pinzgau, in which the Habachtal is located, belonged to the Prince-Archbishopric of Salzburg from 1228 until 1803. ${ }^{22}$ Furthermore, various maps of the Prince-Archbishopric of Salzburg from the first half of the eighteenth century clearly identify the Habach Valley (figure 7). Instead, given the placement in Bavaria, it appears that Brückmann gathered his information from three editions of a booklet by the medical doctor Johann Lehner (born 1623), describing a center for balneotherapy in the modern-day city of Bad Abbach, a few kilometers south of Regensburg. ${ }^{23}$ Mentioned in the booklet's dedication to the Duke of Bavaria is an occurrence of emerald and amethyst located at Bach near Donaustauf, with the stones even being found together within a single piece of host rock. Lehner wrote that the information was given to him by an old stonemason in 1652.

These clues, in turn, add a further mineralogical aspect eliminating any Habachtal connection. The Bach-Donaustauf area is a mining region east of Regensburg, and it was a significant source of fluorite for several hundred years, especially in the nineteenth and twentieth centuries. ${ }^{24}$ An early description mentioned fluorite mining activities in 1703 and 1704 and referred to old tunnels dug even earlier. ${ }^{25}$ Due to the intense green and violet coloration of the fluorites, one of the mines in the area was known as the "Schönfärbiges Bergwerk," translating to "beautifully colored mine." 26 Stated bluntly, there is little doubt that Brückmann's Bavarian "emeralds" were green fluorites.

This only serves to highlight the danger of uncritical repetition and the extent to which information can become entrenched in modern thinking. To cite just a few twentieth-century examples, Scherz wrote (translated from German):27

It is known nowadays, that old necklaces from Pinzgau, in the Salzburg area, contain amongst beautiful regional gemstones such as amethysts and topazes also emeralds. The oldest written description, which mentions these emeralds, is found in a mining chronicle, published in Braunschweig in 1727. This book lists the ores, rocks and stones of the Duchy, to which the Pinzgau area belonged to at this time. In the chronicle, a village Bach (Habach) is described, where green emeralds and blue amethysts are recovered, which might indicate a systematic mining already at the time given.

Edward J. Gübelin (1913-2005) likewise noted:

"In a mining chronicle published in 1727 the emerald 

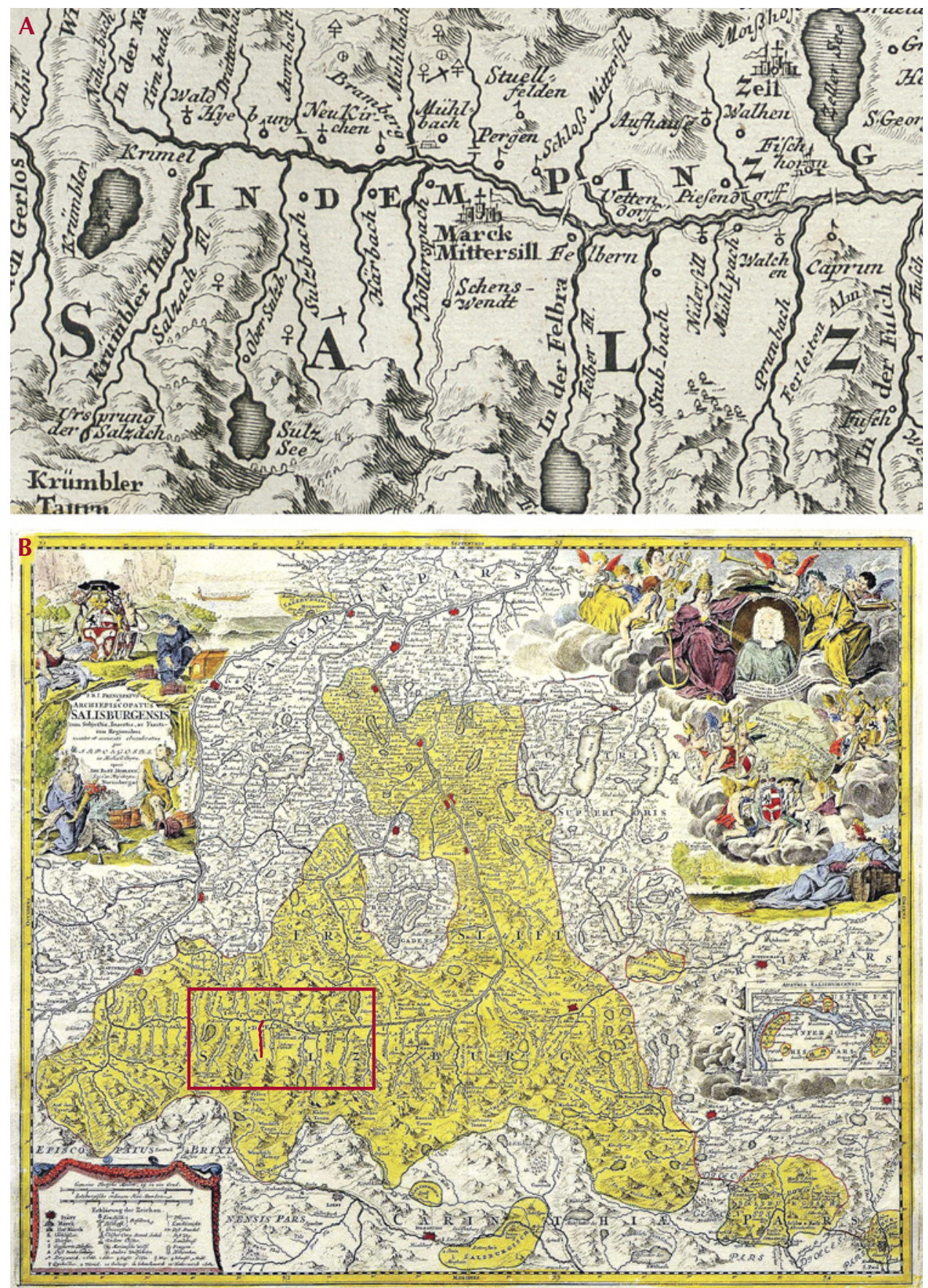

Figure 7. A: Detail from a map by J.B. Homann, Nuremberg 1715, of the Prince-Archbishopric of Salzburg (Archiepiscopatus Salisburgensis), enlarged to show a portion of the Pinzgau west of Zell am See. The area between Hollersbachtal and Sulzbachtal, now known as Habachtal, was referred to as Härbachtal during the eighteenth century (Tal means valley; for further explanation of the name, see also Fabri, 1786). A mining symbol for copper is shown in the Sulzbachtal, and a mining symbol not related to a specific metal is shown between the Härbach and Sulzbach Valleys. B: Map of the Prince-Archbishopric of Salzburg (Archiepiscopatus Salisburgensis) by J.B. Homann, Nuremberg 1715. The territory of the Archbishopric is highlighted in yellow, and Habach Creek is highlighted in red. The creek flows into the Salzach River and is designated on the map by the old name Härbach. The portion of the map enlarged in figure $7 \mathrm{~A}$ is also outlined in red. Both maps courtesy of Bayerische Staatsbibliothek, Munich. of Habachtal is mentioned among ores, rocks and stones of the Duchy of Bavaria, to which the area belonged in the eighteenth century. ${ }^{\prime \prime 2}$ This statement was then relied upon by John Sinkankas, who reiterated the misconception. ${ }^{29}$

The cited examples from Scherz and Gübelin were in turn premised on various articles by Dr. Hans Hanke ${ }^{30}$ that repeatedly made analogous references to the 1727 mining chronicle but never explicitly identified Brückmann as the author.
Oral Traditions from the Eighteenth Century. It appears that, in addition to Anna de' Medici, local residents were aware of the deposit in the eighteenth

\footnotetext{
${ }^{28}$ Gübelin, 1956a, b.

${ }^{29}$ Sinkankas, 1981.

${ }^{30}$ See Hanke, 1938, 1939, 1944. Dr. Hans Hanke (1908-1969) studied geology in Innsbruck and later moved to Salzburg. He worked as a scientific journalist and editor, publishing multiple articles regarding the Alps.
} 


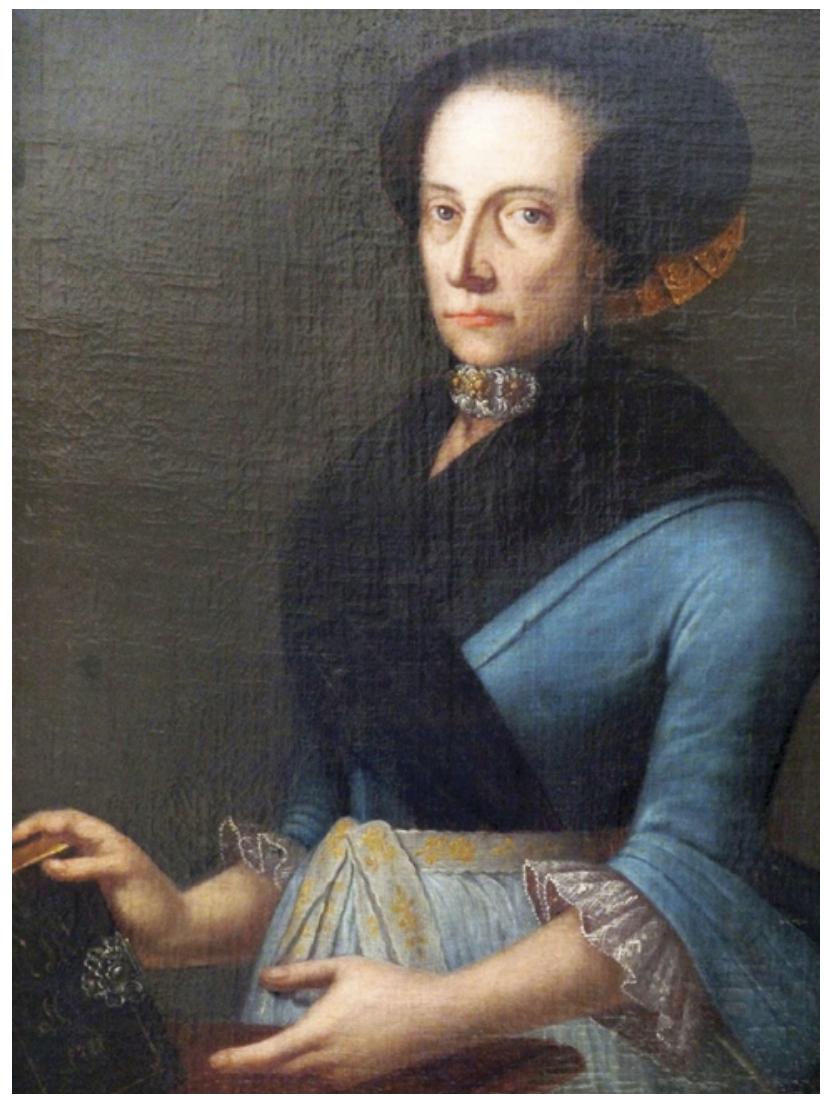

Figure 8. An inventory of the property and possessions of Anna Maria Rottmayrin from Bramberg, a wealthy farmer's widow, listed two emerald rings owned at her death in 1732. The stones are assumed to have been sourced from the Habachtal occurrence. The painting represents her circa 1700; photo by Christina Nöbauer.

century or earlier, collecting and making use of the stones before any mineralogical account of the emerald occurrence was ever published. For instance, the inventory of a wealthy farmer's widow from the village of Bramberg (see again figure 2), Anna Maria Rottmayrin (1648-1732; figure 8), listed two emerald rings owned at her death, and that tabulation has occasionally been relied upon as evidence of use and even mining of Habachtal emeralds during the period. ${ }^{31}$

Furthermore, oral tradition links the emeralds in monstrances housed in churches of the Pinzgau and Salzburg areas to the Habachtal deposit. ${ }^{32}$ Although Colombian emeralds were already available in Europe during the era, the churches' proximity to Habachtal renders such an assumption not unreasonable. Nonetheless, the logic should not be stretched too far, as recently demonstrated by investigation of emeralds in the pectoral cross of Dominikus Hagenauer (1746-1811), presented to him by his father upon his election in 1786 as abbot of St. Peters in
Salzburg. Despite a long-accepted tradition within the monastery that the gemstones had come from the Habachtal deposit, a recent examination by microscopy and energy-dispersive X-ray fluorescence (EDXRF) established them as Colombian emeralds. ${ }^{33}$

Even if there is no indication of regular mining in the eighteenth century or before, the collection of a limited number of emeralds in Habachtal and their use for jewelry over centuries is always possible. However, objects with numerous stones of high quality are always suspicious, especially if they originate from periods in which Colombian emeralds were already available in Europe.

\section{FIRST DESCRIPTION OF HABACHTAL EMERALDS (1797) AND EVENTS UNTIL THE START OF MINING IN 1861}

Leaving aside these four commonly traveled but misleading paths, the first valid published reference to the Habachtal emerald occurrence dates to a 1797 treatise by Kaspar (Caspar) Melchior Schroll (1756-1829; see box A) dealing with minerals from Salzburg. ${ }^{34}$ Schroll simply reported that a prismatic emerald crystal was discovered in a piece of mica schist from that locality. No further information is given. A rapid succession of additional references followed in mineralogical and geological texts, ${ }^{35}$ indicating the information was readily available, albeit with some variance in naming conventions. In the early decades of the nineteenth century, the older designation Heubachtal for the valley was particularly common, ${ }^{36}$ and a number of variations in the name were seen between the sixteenth and nineteenth centuries. ${ }^{37}$

\footnotetext{
${ }^{31}$ Lahnsteiner, 1959; Pech, 1976; Hönigschmid, 1993.

${ }^{32}$ Hanke, 1958; Hagn, 2019.

${ }^{33} \mathrm{~K}$. Schmetzer and H.A. Gilg, unpublished results, 2020.

${ }^{34}$ Schroll, 1797; see also Göttingische Anzeigen von gelehrten Sachen, Vol. 1, Part 83, May 27, 1797, pp. 817-821.

${ }^{35}$ See Reuß, 1801; Haüy, 1804; Mohs, 1804; Klaproth and Wolff, 1810; Zappe, 1817; Jameson, 1820.

${ }^{36} \mathrm{~A}$ note elucidating the name identity between Heubachtal (Heubachthal) and Habachtal (Habachthal) is given, for example, by Ritter von Zepharovich, 1859.

${ }^{37}$ In numerous maps from the sixteenth to nineteenth centuries, the creek now known as Habach Creek was designated Harpach (sixteenth and seventeenth centuries, with the exception of Häbach in Dückher, 1666), Härbach (eighteenth century), or Habach (nineteenth century). Multiple examples are depicted by Schaup, 2000; see also the early geography text by Fabri, 1786. In mining documents from the sixteenth century, Heebach was also used. See Urkunden Salzburg, Erzstift (1124-1805), SLA, OU 1550 I 02, January 1550, SLA, OU 1552 III 10, March 1552;

https://www.monasterium.net/mom/AT-SLA/Erzstift/fond.
} 


\section{Box A: The Quest for Early Habachtal Emerald Samples-The Collections of K.M.B. SCHROLl AND M. MielichHOfER IN SALzburG}

The first published reference to emeralds from the Habachtal occurrence appeared in the 1797 edition of a treatise entitled Grundriss einer Salzburgischen Mineralogie (Outline of Salzburg's Mineralogy) by the scientist Kaspar (Caspar) Melchior Balthasar Schroll (1756-1829). An interesting point to consider is whether the material used by Schroll for his description, or similar pieces from the region and era, remain available in collections today.

Schroll joined the administration of the Prince-Archbishopric of Salzburg in 1777 as a trainee in the mining department (Bergwerkspraktikant). In 1780, he was sent to the Freiberg Mining Academy in Saxony (Bergakademie Freiberg) to study mineralogy, geology, and mining. He then returned to Salzburg in 1792 and thereafter held multiple roles within the Prince-Archbishopric's mining administration, including becoming a mining inspector (Bergrat) in 1793. During the subsequent interim between the end of the Prince-Archbishopric (1803) and Salzburg's accession to the Austrian Empire (1816), he served in several high-ranking positions, and from 1823 until his death in 1829 Schroll was the head of the mining administration. ${ }^{1}$ Schroll authored works focusing on Salzburg's mineralogy, and it was the second edition of the above-cited

Figure A-1. Title page of the 1797 edition of Kaspar Melchior Balthasar Schroll's treatise on the mineralogy of the Prince-Archbishopric of Salzburg, which incorporated the first description of Habachtal emeralds published in a scientific text.

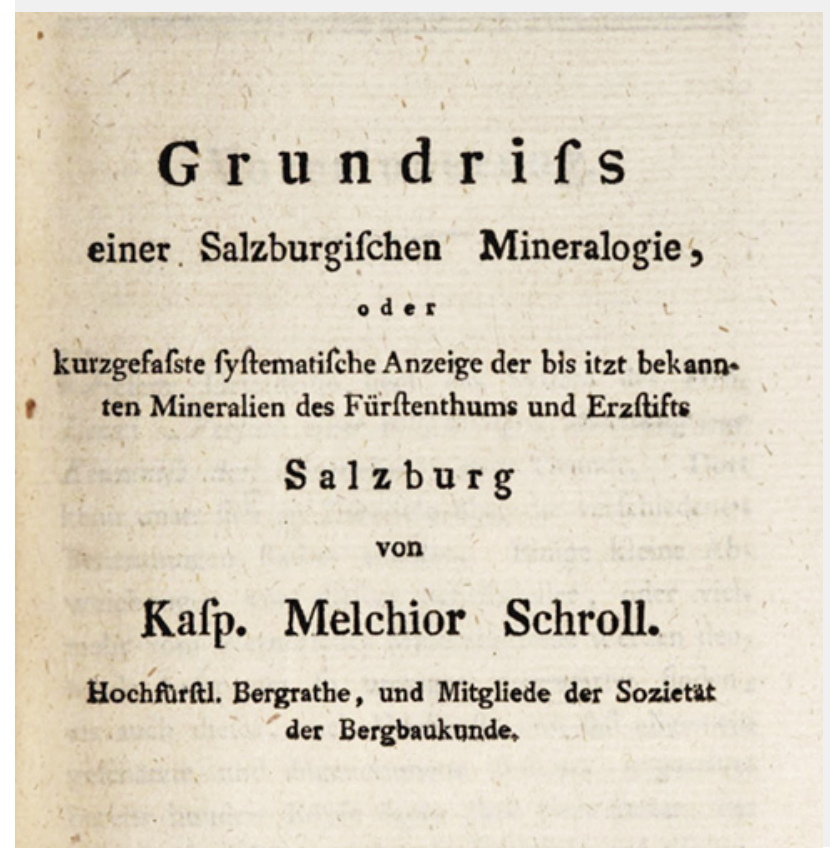

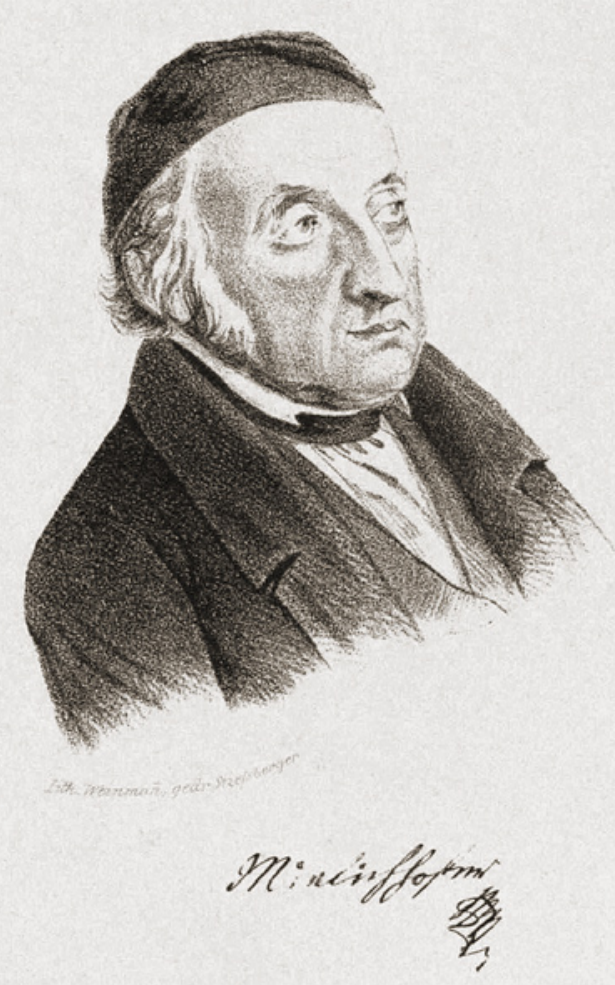

Figure A-2. The collection of Mathias Mielichhofer contains a small number of samples bearing emeralds from Habachtal, thereby demonstrating the sizes of crystals found in the early decades of the nineteenth century. Copper engraving by B. Weinmann, undated; courtesy of Austrian National Library, Vienna.

treatise, published in 1797 (figure A-1), that contained the first brief description of Habachtal emerald material. According to Schroll, the emerald was found by chance when breaking up a piece of mica schist. Schroll also dedicated a portion of his practical work to improving ore processing and smelting.

A generation later, Mathias Mielichhofer (1772-1847; figure A-2) followed a similar career path in Salzburg. Mielichhofer joined the mining department as a trainee in 1794 and was sent to the Freiberg Mining Academy from 1803 to 1805 . He went on to become a mining inspector in 1823 and held that position until his retirement in 1843. In addition to his activities centered on mineralogy and mining, Mielichhofer also became known for several discoveries in the field of botany.

${ }^{1}$ Günther and Lewandowski, 2002. 


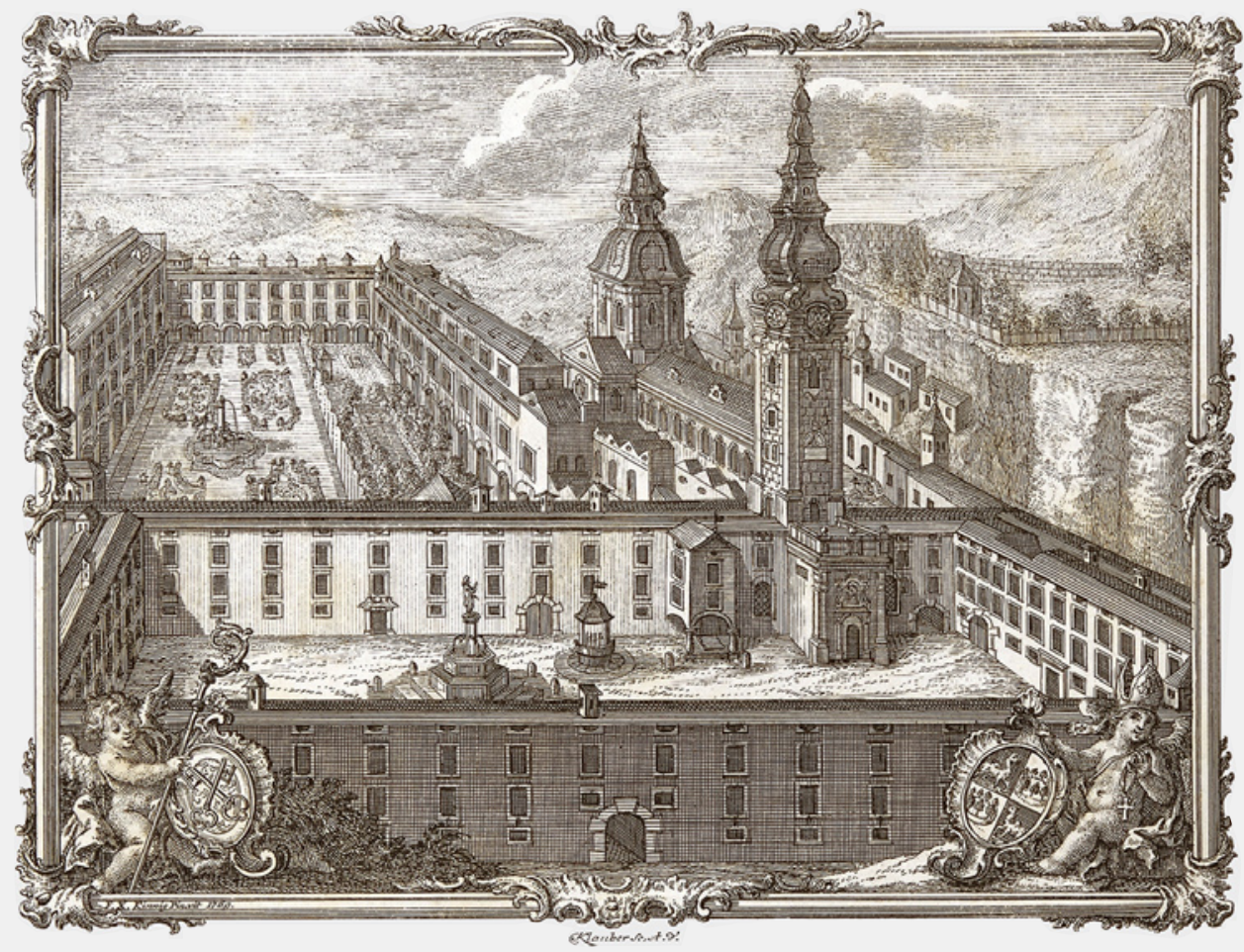

Figure A-3. The mineral collection of St. Peter's Archabbey in Salzburg includes the original collections of Kaspar Melchior Balthasar Schroll and Mathias Mielichhofer, mine inspectors with careers spanning from the late 1700s through the early 1800s. Copper engraving by F. X. Kinnig, 1769; courtesy of St. Peter's Archabbey, Salzburg.

The mineralogical collections compiled by both Schroll and Mielichhofer were later acquired by St. Peter's Archabbey, a Benedictine monastery in Salzburg (figure A-3). Albert Nagnzaun (1777-1856), a passionate mineral collector who became abbot of St. Peter's in 1818 , bought the two collections in 1819 and 1839, respectively, to enlarge the existing collection of the monastery. ${ }^{2}$ Schroll's collection contained around 9,000 to 10,000 pieces, and Mielichhofer's consisted of approximately 3,000 samples. In the most recent decade, a project was undertaken by Norbert E. Urban to catalog the archabbey's collection, endeavoring in particular to assign the various items to the collectors from whence they came. The work relied not only on extant original labels but also old inventories.

Among the items identified to date as most likely sourced from the Schroll collection, none can properly be characterized as emerald. There is, however, a beryl crystal in matrix that, although lacking the green color to be considered emerald, has an original label describing the locality of provenance as "Leckbachscharte im Habachtal." The crystal is $29 \mathrm{~mm}$ in length and has a diameter of $4.5 \mathrm{~mm}$.

Pieces assigned to the Mielichhofer collection, in contrast, include two emerald samples. The first is a crystal in matrix, $18 \mathrm{~mm}$ in length (figure A-4), and the

${ }^{2}$ Rolshoven, 2009.
Figure A-4. Emerald crystal in matrix, $18 \mathrm{~mm}$ in length, from Habachtal, with an original label indicating that it derived from the Mathias Mielichhofer collection acquired in 1839 by St. Peter's Archabbey, Salzburg. Photo by K. Schmetzer.

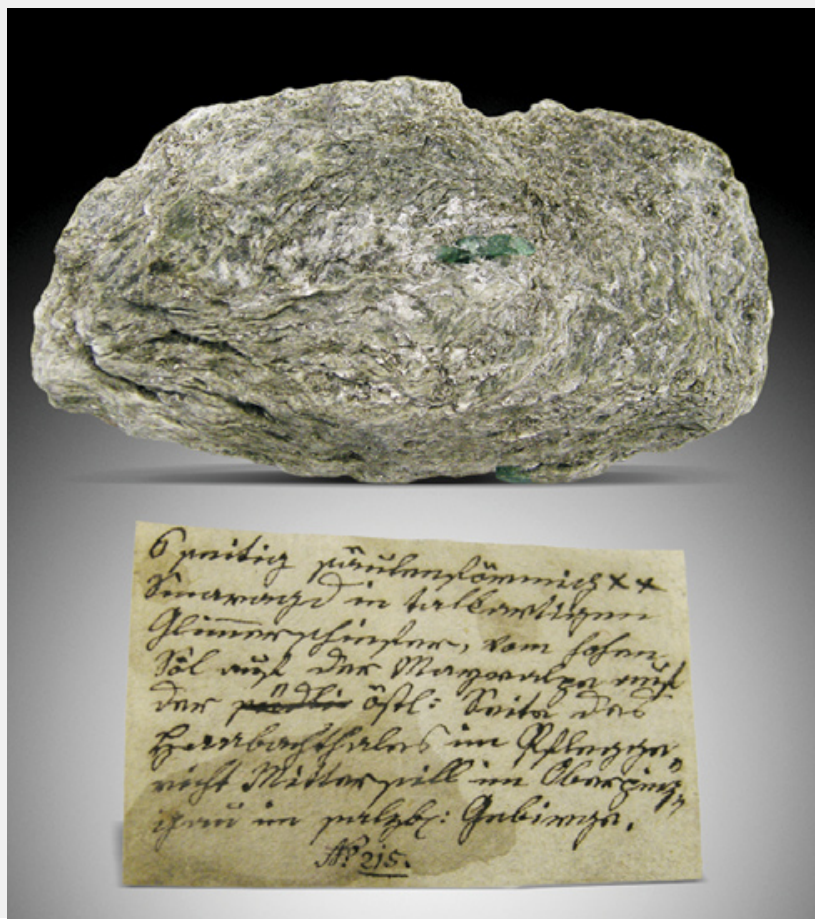




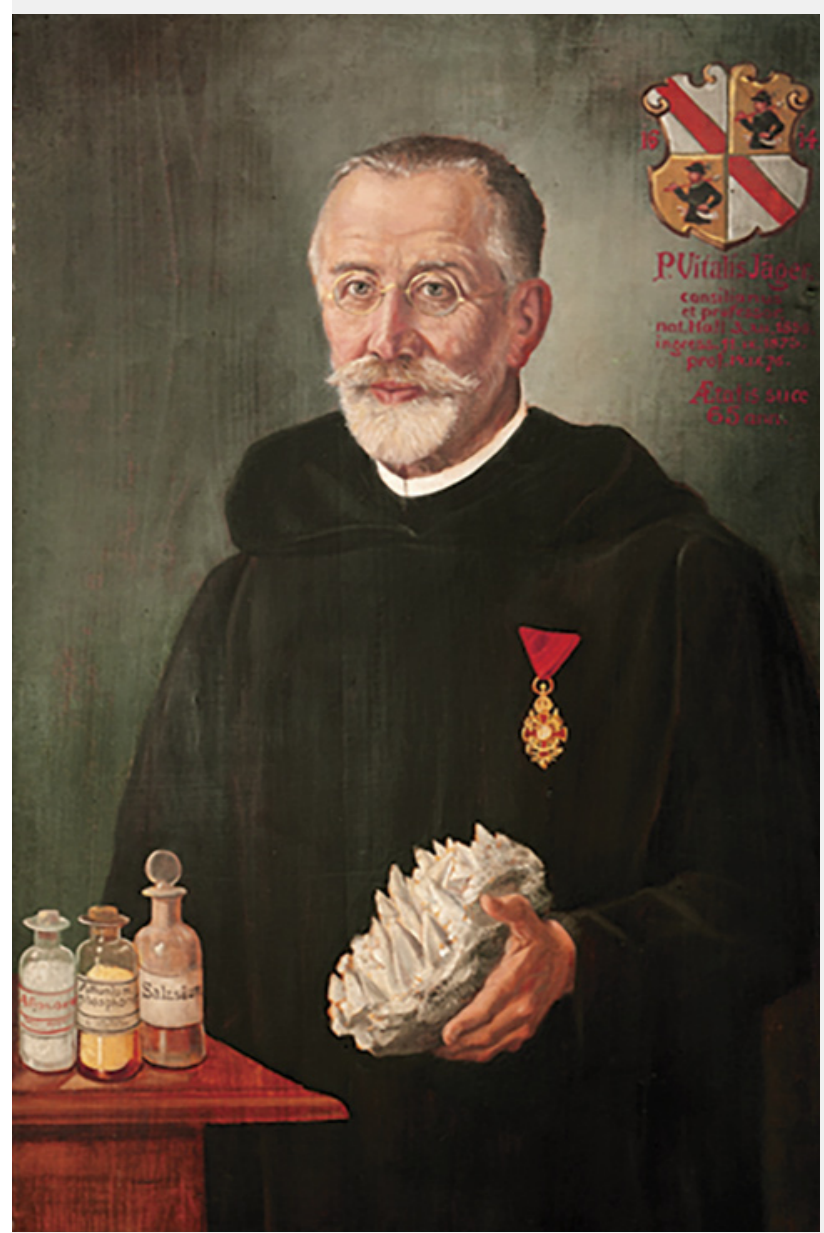

Figure A-5. Portrait of Prior Vital Jäger by G. Scheibenzuber, 1923. Prior Jäger oversaw the mineral collection of St. Peter's Archabbey, Salzburg, for many years and was able to purchase various samples of emerald in matrix from Habachtal during the early decades of the twentieth century. St. Peter's Archabbey, Salzburg, Inventory No. M737.

second is a crystal fragment of $5 \mathrm{~mm}$ in matrix. These examples indicate the sizes and quality of emerald crystals found during the early decades of the nineteenth century, at that time mainly from the secondary deposit downhill, and making their way into the collections of high-ranking individuals within the Salzburg mining administration. In particular, their

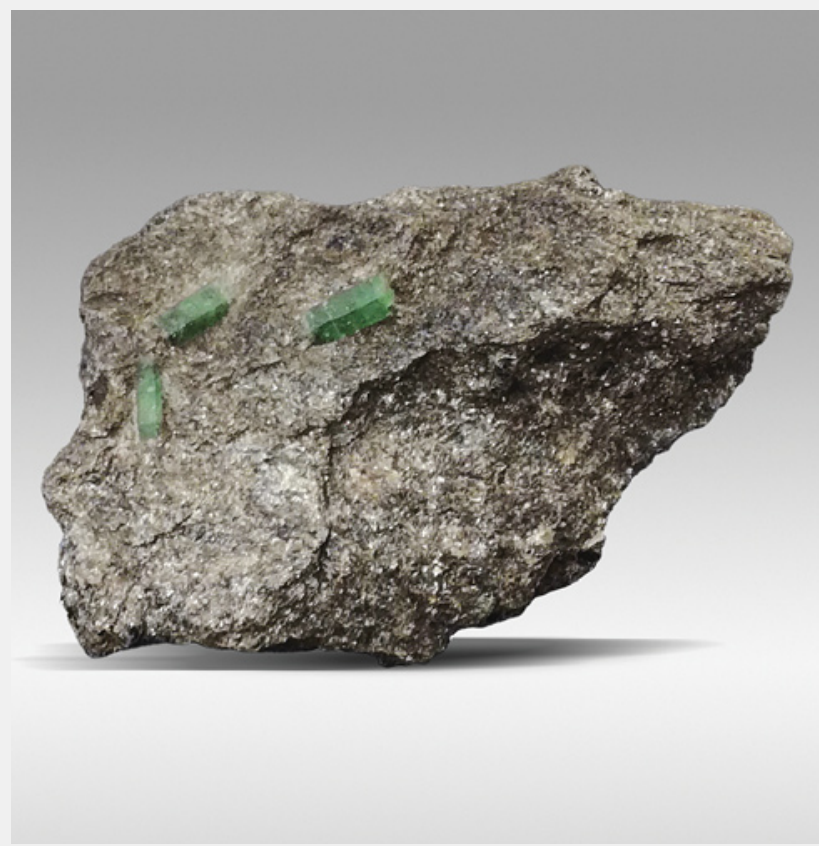

Figure A-6. Emerald crystals in matrix from Habachtal, with the largest crystal measuring $7 \mathrm{~mm}$ in length. The sample was purchased for the collection of St. Peter's Archabbey, Salzburg, in the early twentieth century. Photo by K. Schmetzer.

nature would imply that facet-quality emeralds were extremely rare during the era.

For further comparison and context, the mineral collection of St. Peter's also incorporates samples purchased by Prior Vital Jäger (1858-1943; figure A-5), who oversaw the collection for many years. Some emerald samples in matrix, bought in the early decades of the twentieth century, represent material mined during the period when the Habachtal occurrence was owned by the English entity Emerald Mines Limited. An illustrative example (figure A-6) contains several emerald crystals, the largest with a length of $7 \mathrm{~mm}$. Again, such samples show that a significant percentage of the material mined at Habachtal consisted of collector specimens, not of the size and quality necessary for faceting. A pattern that began with the yield obtained by Samuel Goldschmidt thus continued during the time of Emerald Mines Limited and would be borne out by the tangled history of the mine thereafter.
The new occurrence caused great interest because the only known source at the time was Colombia. The Russian deposits in the Urals would not be discovered for approximately three decades, and al- though the deposits in Egypt were known from descriptions in antiquity, they had been lost in the Eastern Desert for centuries and would only be rediscovered two decades later. 

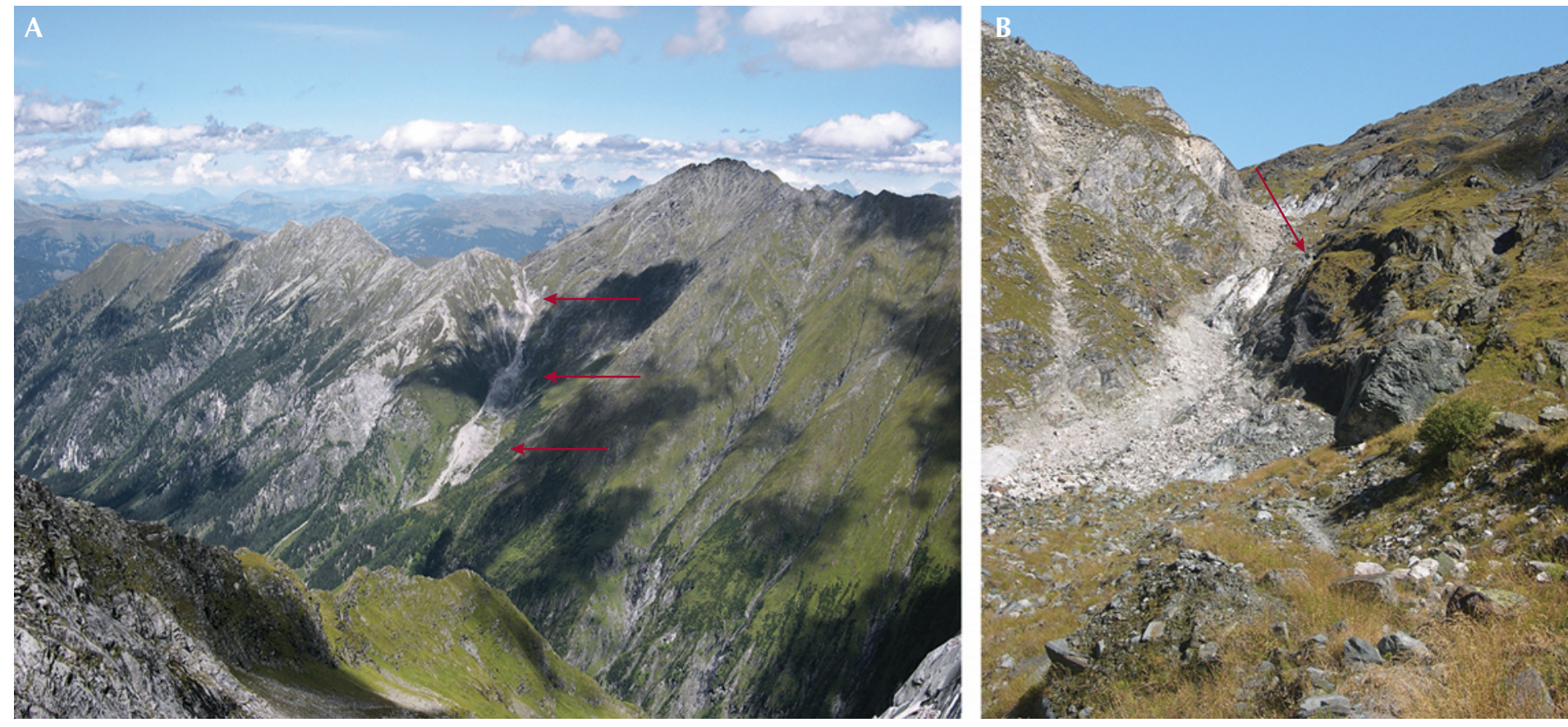

Figure 9. A: The emerald occurrence is located high in the mountain range above the Habach Valley, in a small side valley that includes the secondary deposit known as Leckbachgraben, Leckbachrinne, or Sedl (arrows). The summit area is called Leckbachscharte and represents the transition to the neighboring Hollersbach Valley. B: The large scree field (boulder field) below the outcrop of the emerald-bearing host rocks has traditionally been searched by mineral collectors hoping to find emerald specimens. The arrow points to a small hut for a compressor and other mining tools, built in the second half of the twentieth century. An entrance to one of the underground mining galleries is located close to the hut but is not visible in this view. Photos from 2009 by E. Burgsteiner.

During the early nineteenth century, the Habachtal occurrence was exclusively a secondary source, as the primary emerald-bearing schists would not be discovered until at least $1815 .^{38}$ Secondary samples were collected in the valley close to the primary occurrence and downhill from the emerald-bearing host rocks in a field area known as Leckbachrinne, Leckbachgraben, or Sedl (figure 9), and these were offered in the mineral trade as well. A detailed description, again referring only to secondary materials, was provided in 1821 by the $\mathrm{Mu}$ nich mineral dealer Jakob Frischholz, who visited the locality on several occasions in the 1810s to search for samples. ${ }^{39}$ Even an 1830 travel report mentioned the "famous Habachtal emeralds" but did not refer to any mining activities, although it did note, most likely for the first time, the existence of the uphill primary source..$^{40}$ Only later would it be noted that "emeralds were broken [harvested] from the Smaragdpalfen [a primary emerald-bearing cliff of biotite-schist] at mortal danger." ${ }^{\prime 41}$ More specifically, collectors hung on ropes at the steep cliff but were only able to break off a limited number of crystals in matrix. ${ }^{42}$

Habachtal stones obtained during this era, mostly prismatic crystals in matrix but no faceted stones,

${ }^{38}$ Von Petersen, 1816. Magnus von Petersen (1764-1832) was born in the Duchy of Schleswig, at that time part of Denmark. He studied in Kiel and was a major in the army of the Duchy of Mecklenburg-Strelitz. He also served as educator (Hofmeister) of the Princes of Thurn and Taxis at Regensburg (1813-1822), and in that role he was able to travel to various foreign locales to collect or purchase minerals. Such samples were then submitted to notable scientists for research, such as David Brewster in Edinburgh. On a trip through Tyrol and Salzburg in 1815, Petersen bought several emerald samples in the municipality of Mühlbach, east of Bramberg. After his death, his collection was sold in several parts within Germany, but also to collections in France and England, by his wife, Antoinette von Petersen.

${ }^{39}$ Frischholz, 1821. Jakob (Jacob) Frischholz (1778-1820) was a mineral dealer working in Munich from at least 1808. His written oeuvre included articles dealing with minerals from Tyrol and a publication on the cutting and engraving of gemstones (1820). Through his work,

Frischholz traveled widely to collect or purchase samples, and he was involved in the description of several new or rare mineral species. After his death, his widow Anna (1778-1837) took over operation of the mineral trade business.

${ }^{40}$ Der Bote für Tirol und Vorarlberg, Vol. 1830, No. 20, March 11, 1830, p. 4; for the primary source, see also Russegger, 1835.

${ }^{41}$ Von Kürsinger, 1841; Peters, 1854; Lipold, 1863; Wallmann, 1870; Fugger, 1878.

${ }^{42}$ Von Rosenfeld, 1863. 
can be found in numerous collections, ${ }^{43}$ including those of Schroll and his successor in Salzburg, Mathias Mielichhofer (1772-1847) (see again box A).

\section{THE LEGAL CONTEXT OF AUSTRIAN MINING LAW}

Attendant to the transition to formal mining, it is important to understand the legal context. Applicable throughout the Austro-Hungarian Empire from the mid-nineteenth century on was the General Austrian Mining Law dated May 23, $1854 .{ }^{44}$ That statute established a bifurcated regime, differentiating between minerals regulated by the scheme set forth therein (vorbehaltene Mineralien) and minerals regulated only by broader and more generalized commercial legislation (nicht vorbehaltene Mineralien). For ores and minerals covered by the mining act, rights to and ownership of mined minerals were controlled independently of the land from which they were extracted. Any exploitation of covered minerals would begin with an application for an initial exploration and development permit (referred to hereafter as an exploration permit). Such would authorize early exploratory and development activities, including limited mining, even underground, until it could be determined whether the deposit was of economic value. Under such an exploration permit, the holder was entitled to a largely unrestricted right of access for the purposes covered by the permit and could not be constrained or limited by the landowner. Once economic value was ascertained, a mining privilege would need to be granted for further exploitation, and the holder of such mining rights-not the landowner-would own the underlying minerals.

For ores and minerals not falling within the purview of the mining act, rights and ownership remained with

\footnotetext{
${ }^{43}$ See Niedermayr, 1988, 2003; Grundmann, 1991.

${ }^{44}$ See commentaries by von Gränzenstein, 1855; Stamm, 1855; Manger, 1857; Leuthold, 1887; Schlüter, 1938; Schoen, 1939.

${ }^{45}$ See Manger, 1857; Haberer and Zechner, 1884.

${ }^{46}$ Vienna Holdings, Jewish Family Lists, Archive of the Jewish Community in Vienna; family name also written Goldschmid or Goldschmitt.

${ }^{47}$ See Redl, 1813; Wiener-Zeitung, No. 119, May 26, 1820, p. 5. Two of Samuel Goldschmidt's brothers, Salomon Johann Nepomuk Goldschmidt (1808-1855) and Wilhelm Goldschmidt (born 1814), eventually joined their father, operating as "J. Goldschmidt \& Söhne." Upon the father's death and Wilhelm's departure, Salomon continued the business as "J. Goldschmidt \& Sohn." Wilhelm then briefly associated with Samuel before running his own short-lived company from 1842 to 1844. Salomon would also go on to lease the Hungarian opal mines from 1845 to 1855 , which lease was then maintained by his widow Emilie and son Adolf Louis until 1880. Semrád, 2015. For genealogy of the Goldschmidt family, see also Gaugusch, 2011; Semrád, 2012.
}

the landowner. Any commercial activities would be circumscribed by the Austrian Trade, Commerce and Industry Regulation Act of 1859 and/or, to the extent relevant, the Austrian Decree for the Admission of Foreign Joint-Stock Companies of 1865.

Complicating the framework was the fact that the mining law of 1854 provided no explicit list of the minerals to which it applied. Rather, applicability had to be decided on a case-by-case basis. While in some instances coverage was obvious-such as with copper, lead, or zinc minerals from which large quantities of metal could be extracted-in other cases, controversy could arise. According to the generally accepted legal interpretation, gemstones were excluded, meaning that emerald would typically be treated as the property of the landowner. ${ }^{45}$ However, to the extent that gemquality emeralds might be produced as an adjunct to beryllium minerals and ore extracted under separate rights per the mining law, they could be sorted, faceted, and sold by the permit holder. The result was a legal loophole that facilitated bypassing the rights that a landowner would otherwise hold to the gemstones.

An additional complication came from the fact that while mining privileges were granted for specific minerals or ores, exploration permits could be obtained merely by specifying a geographic area. Thus, as a practical matter, exploration permits were in general sought as an initial step to maximize options, regardless of the intended mineral target. Two types of permits appear to have been available, one covering a broader area and the other covering a smaller circle. The former could comprise an entire valley, a mountain range, and so forth, while the latter covered a circle with a radius of 425 meters (referred to as a Freischurf). Insofar as exploration permits were not exclusive, it was possible for multiple, overlapping permits to be granted to different parties, meaning that several individuals or companies could be authorized to perform activities in the same area (figure 10).

\section{MINING HISTORY OF THE HABACHTAL EMERALDS (1861-1914)}

Property Under the Goldschmidt-Brandeis Family (1861-1894). Mining for emerald in Habachtal commenced in the early 1860s, guided by Samuel Goldschmidt (1810-1871), a jeweler from Vienna who established a firm operating as "S. Goldschmidt" in 1839. Samuel Goldschmidt hailed from a family involved in the gemstone and jewelry trade. His father, Joseph Goldschmidt (1789-1841), ${ }^{46}$ founded a business in that field in Vienna in $1813 .{ }^{47}$ In the following 


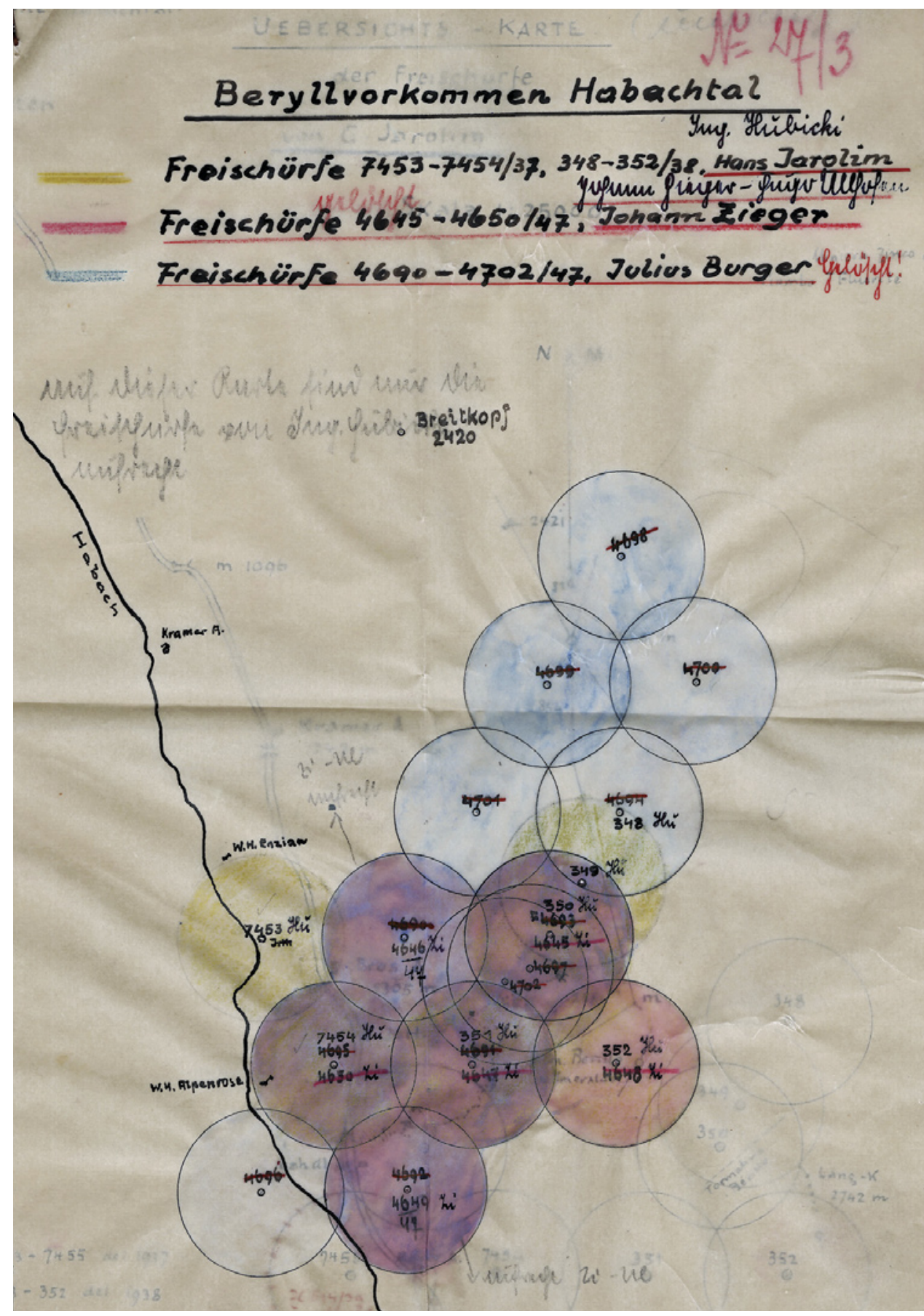

Figure 10. Under Austrian law, overlapping exploration permits could be granted to multiple parties, as seen in this map for the area of the Habachtal emerald mine from the 1940s and 1950s. Three different individualsHans Jarolim (greenish yellow), Johann Zieger (purple), and Julius Burger (blue)-had each been authorized to perform activities over several circles with a radius of $425 \mathrm{~m}$ each. File Beryl Bramberg, Collection of W. Günther, Archive of the Bergbau- und Gotikmuseum Leogang.

decades, Joseph Goldschmidt and his three sons were involved in several Vienna-based gem and jewelry firms.

Following publication of a geological study of emerald-bearing rocks in Habachtal by Karl Ferdinand Peters, a geologist at the k.k. geologischen Reichsanstalt (Austrian geological survey), ${ }^{48}$ in August 1861 Samuel Goldschmidt obtained an exploration permit for the entire Habachtal Valley, including the western and eastern slopes. ${ }^{49}$ Goldschmidt undertook exploration for samples in the

${ }^{48}$ Peters, 1854. Karl (Carl) Ferdinand Peters (1825-1881) was a geologist at the k.k. geologischen Reichsanstalt from 1852 to 1855. Later he became a professor for geology and mineralogy at multiple universities, including those in Budapest, Vienna, and Graz.

${ }^{49}$ Initial permit dated August 29, 1861, for a term of one year, with additional one-year extensions dated August 15, 1862, and August 1, 1863. Archive of the Municipality of Bramberg. 


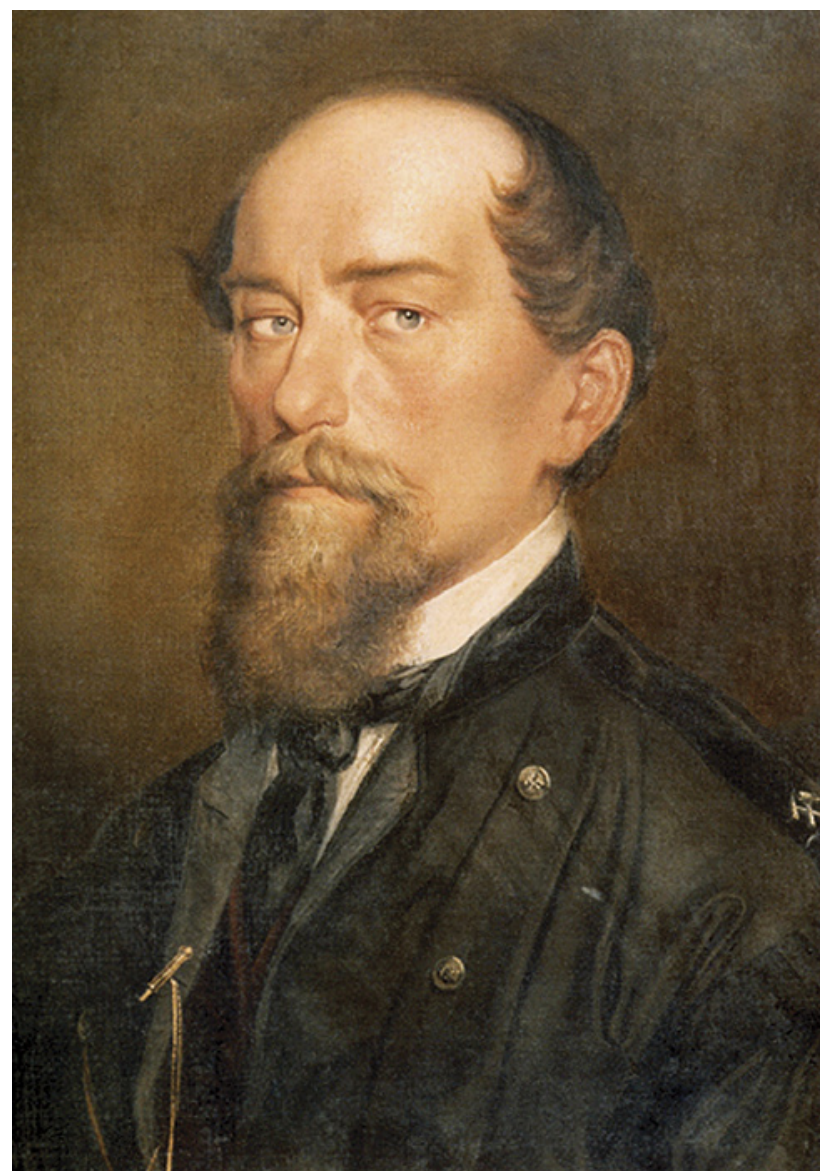

Figure 11. Markus Vinzenz Lipold, a geologist at the k.k. geologischen Reichsanstalt (Austrian geological survey) in Vienna, guided Samuel Goldschmidt on his excursion to Habachtal in 1861. Portrait 1869, by Karl Scharak.

summer of $1861,{ }^{50}$ assisted by Markus Vincenz Lipold (figure 11), ${ }^{51}$ and their efforts proved successful. Insofar as mining of gemstones was not sanctioned through the mining law but only through land ownership, ${ }^{52}$ Goldschmidt in November 1861 obtained authorization to buy the area of interest. A purchase from the governmental treasury of 175 Joch (approximately one square kilometer; figure 12) was consummated in February 1862 for 1,000 Gulden (equivalent to about 2,000 Kronen, or US\$400 according to the exchange rate for the era). ${ }^{53}$ The parcel included portions situated in two different tax regions, namely Habach (Area No. 850) and Hollersbach (Area No. 317) (figure 13).

In late spring 1862 , the S. Goldschmidt firm presented emerald crystals in host rock, found in the large scree field (boulder field) of the Leckbackrinne

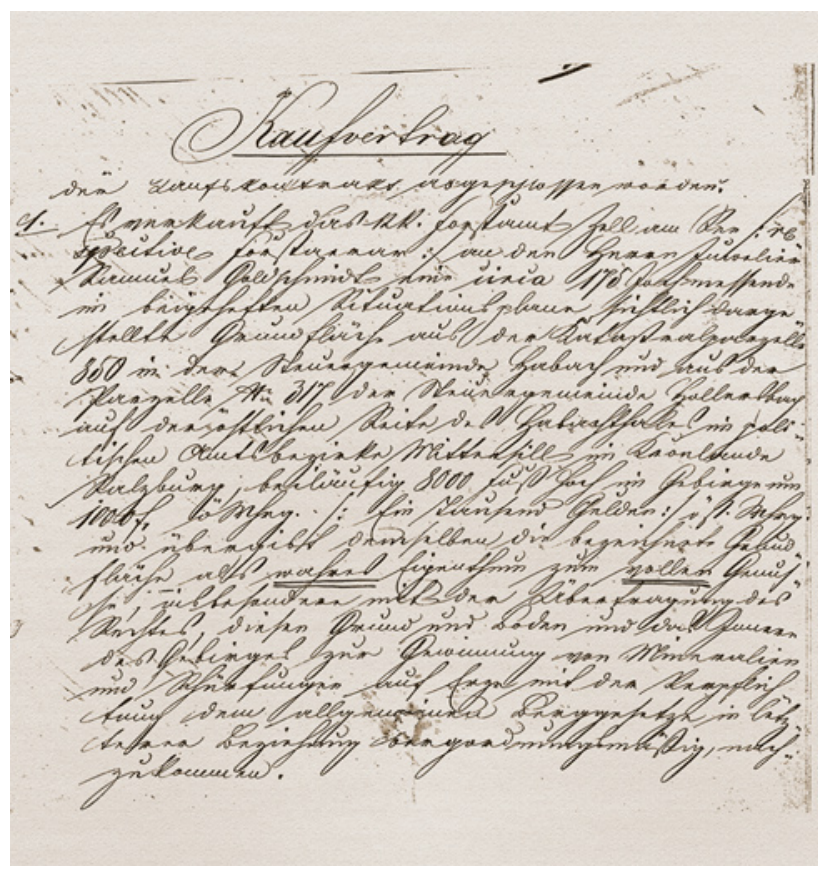

Figure 12. Page one of the notarized contract between the Austrian government and Samuel Goldschmidt setting forth the area purchased and the price. Archive of Peter Lausecker, Kirchhundem, Germany.

downhill from the primary emerald-bearing biotite schist, at the Agricultural, Industrial and Art Exhibition in London. ${ }^{54}$ Regular mining started in 1862 , combined with further exploration activities in 1863. Through that work, it became apparent that the primary emerald-bearing rock was not confined to the

${ }^{50}$ Haidinger, 1861.

${ }^{51}$ Bergrath Markus Vincenz (Marko Vincenc) Lipold (1816-1883) worked as a geologist at the k.k. geologischen Reichsanstalt from 1849 to 1867 . From 1867 on, he was the director of the mercury mine at Idria. Verhandlungen der Geologischen Reichsanstalt, Vol. 1883, No. 9, pp. 183-184.

${ }^{52}$ See von Gränzenstein, 1855; Stamm, 1855; Manger, 1857; Leuthold, 1887.

${ }^{53}$ Notarized contract between k.k. Forstamt Zell am See (Forstaerar) and Samuel Goldschmidt, February 10, 1862, Peter Lausecker reference collection; Habachtal emerald mine file (Edelsteinbergwerk im Habachthale), entry March 29, 1862, Mittersill land registry office (Grundbuchamt Mittersill), Grundbucheinlage 155, Parzelle 850 und Parzelle 317, Archive of Salzburg Federal State (Land Salzburg, Landesarchiv) (hereinafter cited only to the Mittersill land registry office); Salzburger Zeitung, No. 108, May 12, 1862, p. 3; Bukowina, No. 55 May 20, 1862, p. 2; Volks- und Schützen-Zeitung, Vol. 17, No. 63, May 26, 1862, p. 5; Grundmann, 1979; Lausecker, 1986; Lewandowski, 1997.

${ }^{54}$ Wiener Zeitung, No. 263, November 12, 1861, pp. 1-2; Salzburger Zeitung, No. 108, May 12, 1862, p. 3; Waldheim's Illustrierte Zeitung, No. 21, May 24, 1862, pp. 2-3; Arenstein, 1862; Peters, 1862. 


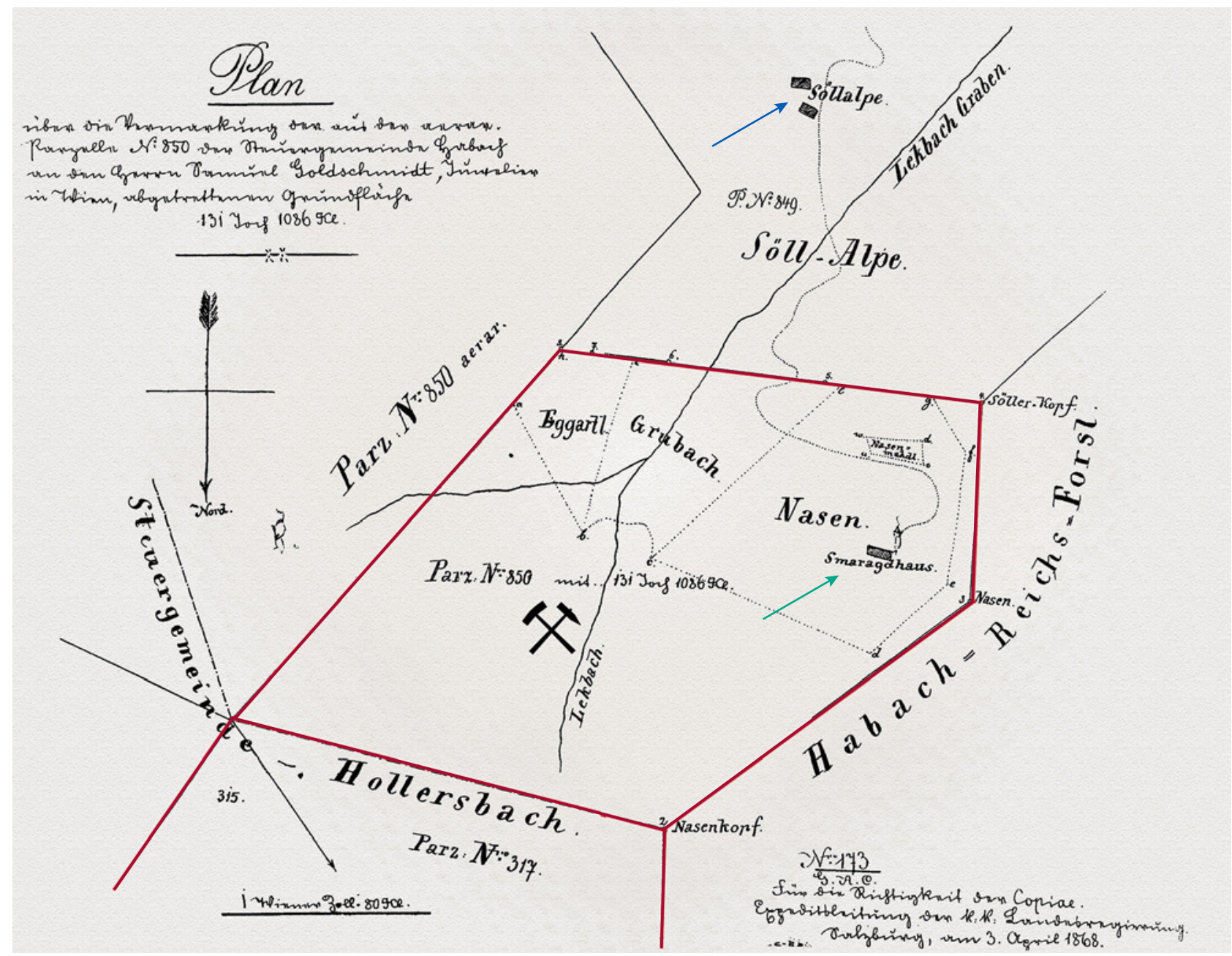

Figure 13. A map dated 1868 showing the area incorporating the emerald occurrence purchased by Samuel Goldschmidt from the Austrian government. Included is the stone residence labeled "Smaragdhaus" (emerald house, green arrow), built for the miners by Goldschmidt and still known as "Goldschmidthütte" (Goldschmidt's hut). Two other huts in the area, designated Sedl-Alm (blue arrow), may also have been used by the miners or emerald collectors at various times. Remains of these buildings are still visible. In the notarized contract from February 1862, the area purchased by Goldschmidt was given in old Austrian units as a parcel of 175 Joch, consisting of Area No. 850 (131 Joch 1086 Kl [Klafter]) and Area No. 317. Archive of the Municipality of Bramberg, with a hammer and pick symbol showing the approximate position of the mining area added by the author.

so-called Smaragdpalfen but, rather, extended to larger areas of mica schist. ${ }^{55}$

During Goldschmidt's operation of the property, only open-pit surface mining was performed until August $1863 .{ }^{56}$ Thereafter, three tunnels were apparently dug (figure 14). ${ }^{57} \mathrm{~A}$ stone residence was constructed nearby to provide accommodations for the miners. Historical documentation referred to the structure as "Smaragdhaus" (emerald house, see again figure 13), and it is still known as "Goldschmidthütte" (Goldschmidt's hut). In his jewelry store in Vienna, Goldschmidt offered Habachtal rough emerald crystals in matrix and published advertisements aimed at mineral collectors (figure 15). ${ }^{58}$ Conversely, the quantity of facet-quality emeralds was too low either to support advertisement or to sus-

\footnotetext{
${ }^{55}$ Lipold, 1863.

${ }^{56}$ Letter by S. Goldschmidt, August 20, 1863. Archive of P. Semrád, Bergen, The Netherlands.

${ }^{57}$ Lipold, 1863; Wallmann, 1870.

${ }^{58}$ Fremden-Blatt, Vol. 18, No. 127, May 8, 1964, p. 23
} 


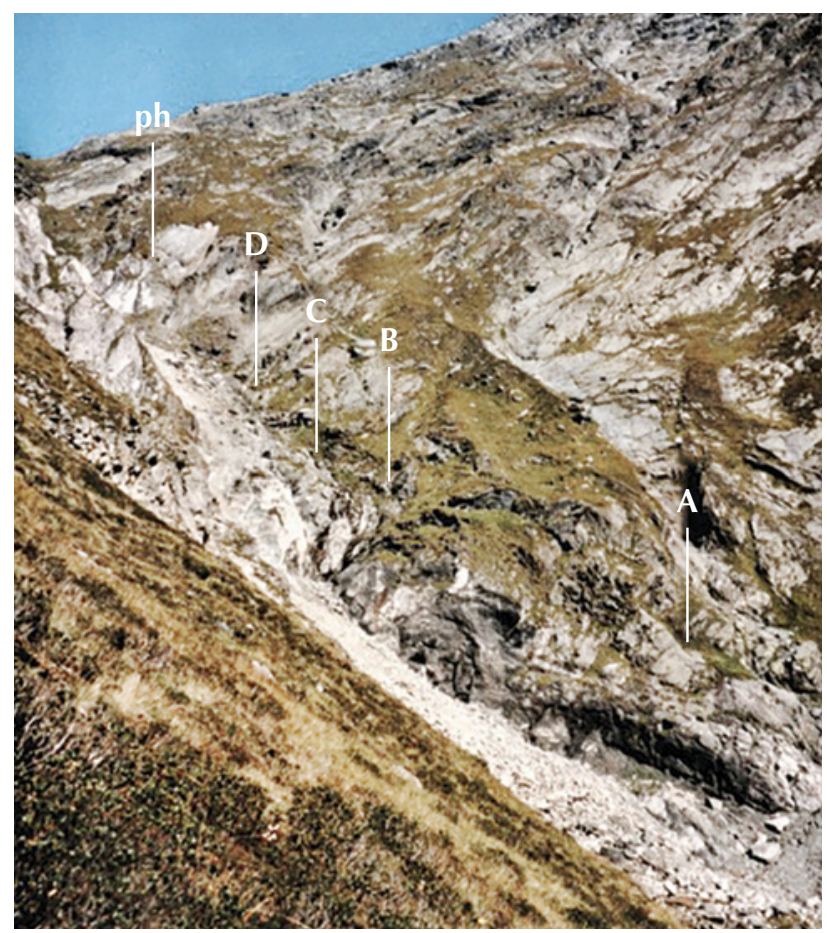

Figure 14. Four underground galleries in Leckbachgraben $(A-D)$ were worked by the English firm Emerald Mines Limited, after initial tunneling had begun under Samuel Goldschmidt. An occurrence of large phenakite crystals (ph) is also shown. Photo from August 1977; courtesy of G. Grundmann.

tain mining operations, which terminated after only a few years. ${ }^{59}$

Nonetheless, it appears that at least a limited number of faceted Habachtal emeralds found their way into the production of jeweled pieces during the period. Potentially illustrative is a silver goblet lid made by the Hermann Ratzersdorfer jewelry factory in Vienna between 1850 and 1880 (figure 16A) and decorated with emeralds. Based on their visual

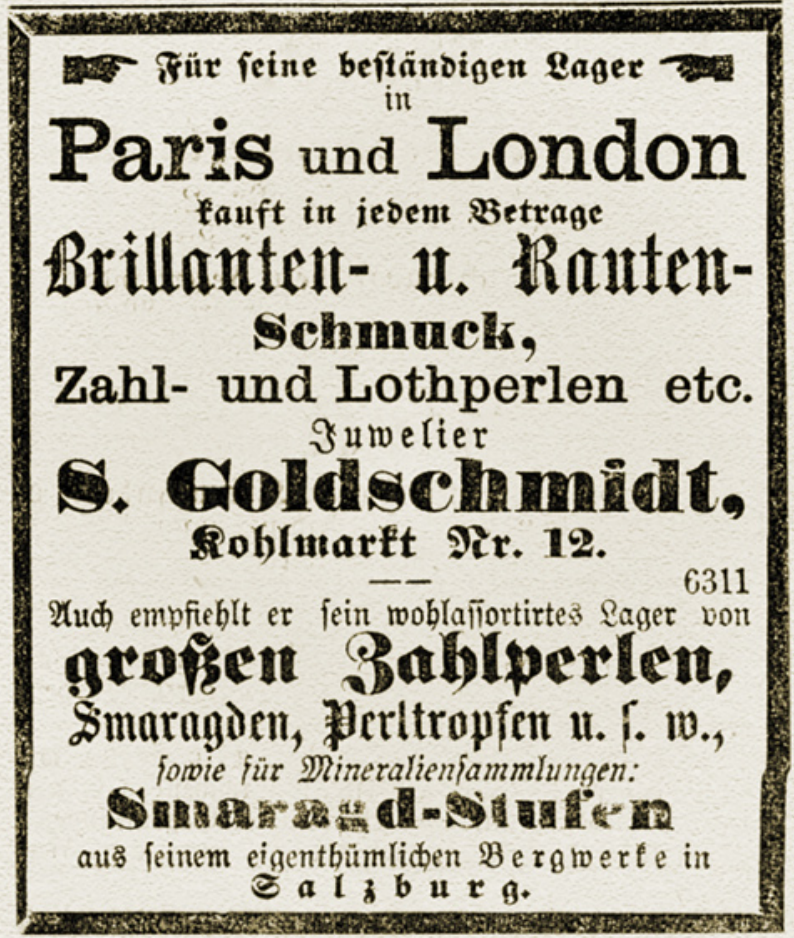

Figure 15. The S. Goldschmidt firm ran an advertisement in the daily newspaper Fremden-Blatt in May 1864 offering mineral collectors rough emeralds in matrix from the company's proprietary mine in Salzburg.

appearance-heavily included with a mainly light to medium green color (figure 16B; see also box A and figure 17) — these could have originated from the deposit.

Goldschmidt died in July $1871 .{ }^{60}$ As his will, with a final codicil from $1869,{ }^{61}$ did not provide for disposition of the Habachtal mine, ownership fell to his daughters Jeanette (1846-1924) and Friederike (18511911). Jeanette's husband, Albert Brandeis, ${ }^{62}$ oversaw affairs related to the mine.

\footnotetext{
${ }^{59}$ Peters, 1867; Trautwein, 1870; correspondence between the Mittersill tax office and the municipality of Bramberg, April 1874, Archive of the Municipality of Bramberg. The correspondence stated that Goldschmidt mined for two years only, but it is unclear whether this implies one season each of open-pit mining (1862) and underground mining (1863) or two years of underground mining (1863 and 1864).

${ }^{60}$ Leitmeier, 1938; Eberl, 1972; Lausecker, 1986. A death notice published in the daily newspaper Neue Freie Presse (No. 2479, July 21, 1871, p. 16) described Goldschmidt as a jeweler, a jewelry evaluator at the "Lord High Steward's Office," an honorary citizen of Vienna, and a member of several scientific associations.

${ }^{61}$ Will of Samuel Goldschmidt, 1856, with codicils, Archive of the City of Vienna [Wiener Stadt- und Landesarchiv].

${ }^{62}$ Albert Brandeis (1844-1910) was a descendant of the Weikersheim-Brandeis family of merchants and bankers mainly involved in the Viennese "M.H. Weikersheim \& Comp." and related entities. In the 1870s, he served on the boards of directors at various banks and insurance companies. From 1882 on, he was one of the directors of the Illyrische Quecksilberwerke Gesellschaft located in Idria (Idrija), in present-day Slovenia. For several centuries, the Idria area was one of the largest mercury-producing regions worldwide. Given this connection, Brandeis likely became knowledgeable about matters related to mining and mining investments. However, he apparently was not a particularly successful businessman. Die Presse, Vol. 35, No. 76, March 17, 1882, p. 7; Will of Albert Brandeis, 1910, Archive of the City of Vienna (Wiener Stadt- und Landesarchiv); Amtsblatt zur Wiener Zeitung, No. 19, January 24, 1911, p. 3.
} 

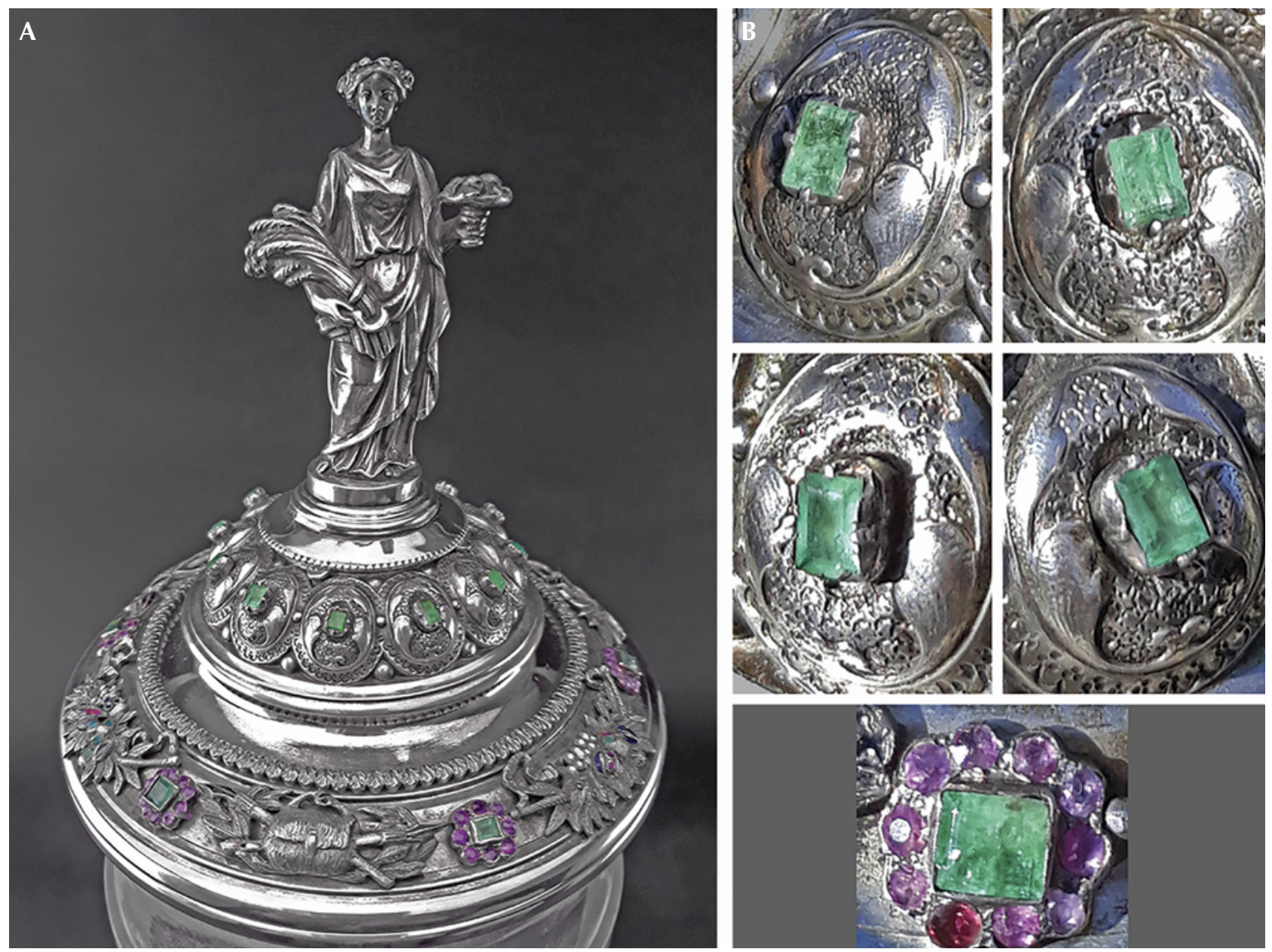

Figure 16. A: Silver goblet lid depicting Ceres, the goddess of agriculture, manufactured by the Hermann Ratzersdorfer jewelry factory in Vienna and consistent in style with the type of Renaissance revival jewelry produced there between 1850 and 1880. B: The lid is decorated with emeralds that, according to visual features such as color and inclusions, could have originated from the Habachtal deposit. The diameter of the lid is $155 \mathrm{~mm}$, and the emeralds are approximately $6 \times 4 \mathrm{~mm}$ (top and middle rows) and $6 \times 5 \mathrm{~mm}$ (bottom row). Photos by Manfred Wild, Emil Becker company, Idar-Oberstein.

Following Goldschmidt's death, the mine appears to have been leased on one or more occasions. Information provided in the 1930s by Ernst Samuel Brandeis (1872-1942), Albert's son, suggests that the mine was leased for a few years under a contract terminating in 1875 and bringing to a close formal mining activities. ${ }^{63}$ In contrast, an anonymous report circa $1917^{64}$ implies that the mine was leased to Andreas (Andrä) Bergmann (1813-1882) from Innsbruck for five years and to Alois Wurnitsch (1834-1909) from Bramberg $^{65}$ for six years. Both were involved with the epidote deposit in the Untersulzbach Valley, west of Habachtal. Wurnitsch discovered the material in approximately 1865 , and his friend Bergmann leased and worked the deposit, with interruptions, from about 1867 to $1881 .{ }^{66}$ It is feasible that they pursued limited mining or exploration at Habachtal in conjunction

\footnotetext{
${ }^{63}$ Leitmeier, 1938.

${ }^{64}$ Anonymous (written on paper with the company logo "Carl Staudt, Holzhandlung, Traunstein," most likely by A. Hager), Das SmaragdBergwerk im Habachthale, circa 1917, 6 pp., Archive of the Municipality of Bramberg.

${ }^{65} \mathrm{Alois}$ Wurnitsch moved in 1882 or even before to Bramberg, where he died in 1909 and some of his family members continued to live. Archive of the Municipality of Bramberg, J. Seifriedsberger, pers. comm., 2020.

${ }^{66}$ Ritter von Zepharovich, 1869; Seemann et al., 1990, 1993; Günther, 1994.
} 


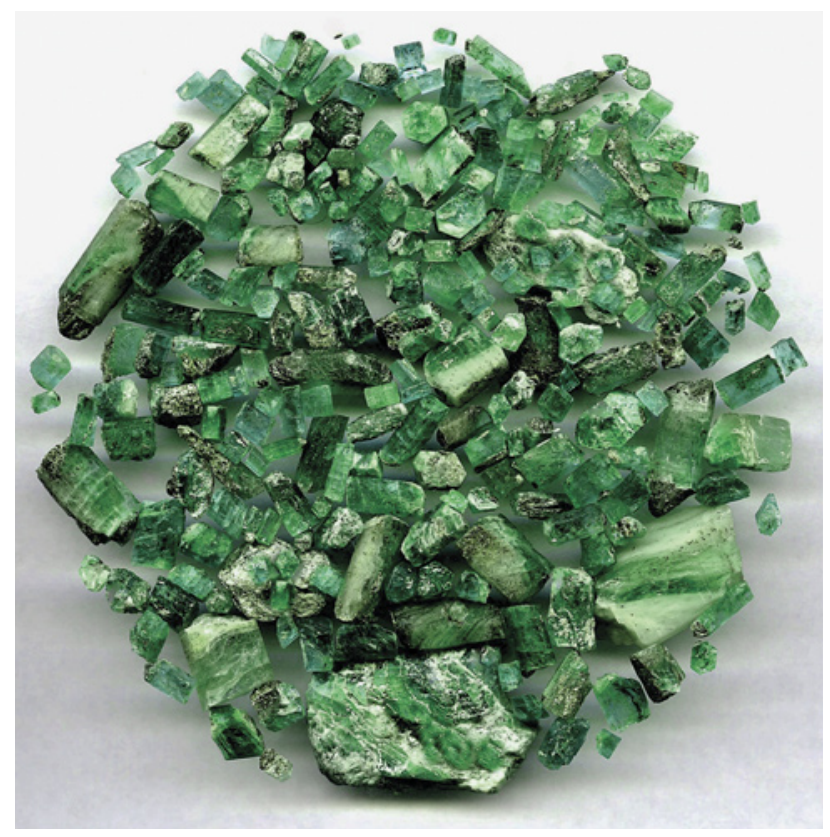

Figure 17. These emeralds used by G. Grundmann for his research on Habachtal show the typical quality coming out of the mine in the 1960s and 1970s. Courtesy of G. Grundmann.

with their other activities. This is verified by the purchase of two emeralds (together with minerals from the Untersulzbach epidote deposit) by the British Museum in London from the Bergmann company in 1872 and $1883 .{ }^{67}$ The first example is a crystal in matrix, and the latter is an extraordinarily large crystal of 3.3 $\mathrm{cm}$ in length and $82 \mathrm{ct}$ in weight (figure 18). Reported as having been found during this period was another large single crystal of $3.5 \mathrm{~cm}$ in length and 2 to $3 \mathrm{~cm}$ in diameter, a specimen now in the collection of the Natural History Museum, Vienna. ${ }^{68}$

After the leaseholds terminated, the emerald mine rested largely dormant for the next two decades, with locals making occasional small-scale

\footnotetext{
${ }^{67}$ R. Hansen, Natural History Museum, London, pers. comm., 2021. ${ }^{68}$ Salzburger Volksblatt, Vol. 4, No. 71, March 30, 1874, p. 3; Tschermak, 1874.

${ }^{69}$ Freie Stimmen, Vol. 12, No. 13, January 30, 1892, pp. 1-3.

${ }^{70}$ Report by Josef Lahnsteiner, 1942 (relying upon personal communication with Karl Wurnitsch), Archive of Alfred Lahnsteiner, Hollersbach.

${ }^{71}$ Notarized contract between Friederike Goldschmidt and Albert Brandeis, March 1, 1894, Mittersill land registry office, Archive of Salzburg Federal State; Habachtal emerald mine file, entry March 9, 1894, Mittersill land registry office; Grundmann 1979; Lausecker, 1986.
}

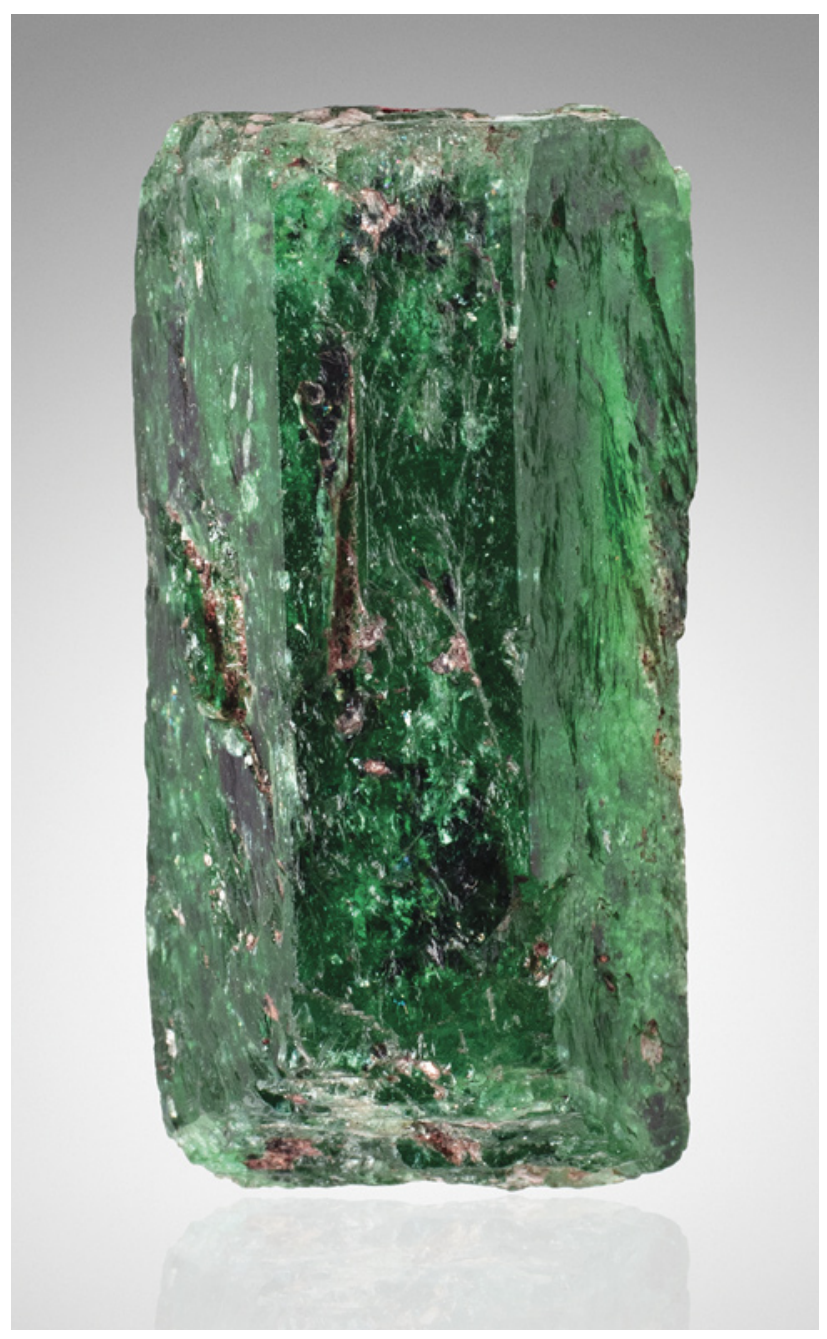

Figure 18. This emerald crystal from Habachtal, 3.3 $\mathrm{cm}$ in length and weighing $82 \mathrm{ct}$, was sold by the Bergmann company in 1883 to the British Museum, London; it is one of the largest samples from Habachtal found in the nineteenth century. Courtesy of the Natural History Museum, London, (C) The Trustees of the Natural History Museum, London.

finds. ${ }^{69}$ More intense activity was not entirely absent, however, as Wurnitsch continued to work in the area, even using dynamite, assisted by his son Karl (1871-1949; figure 19). ${ }^{70}$

In March 1894, Albert Brandeis purchased Friederike's half of the property for a symbolic price of 200 Gulden (equivalent to about 400 Kronen, or US $\$ 80$ according to the exchange rate for the era). ${ }^{71}$

Transfer to the English Emerald Mines Limited (1894-1896). Nonetheless, it seems that the Brandeis family did not wish to take on the expense or risk of developing the mine and instead turned to family 


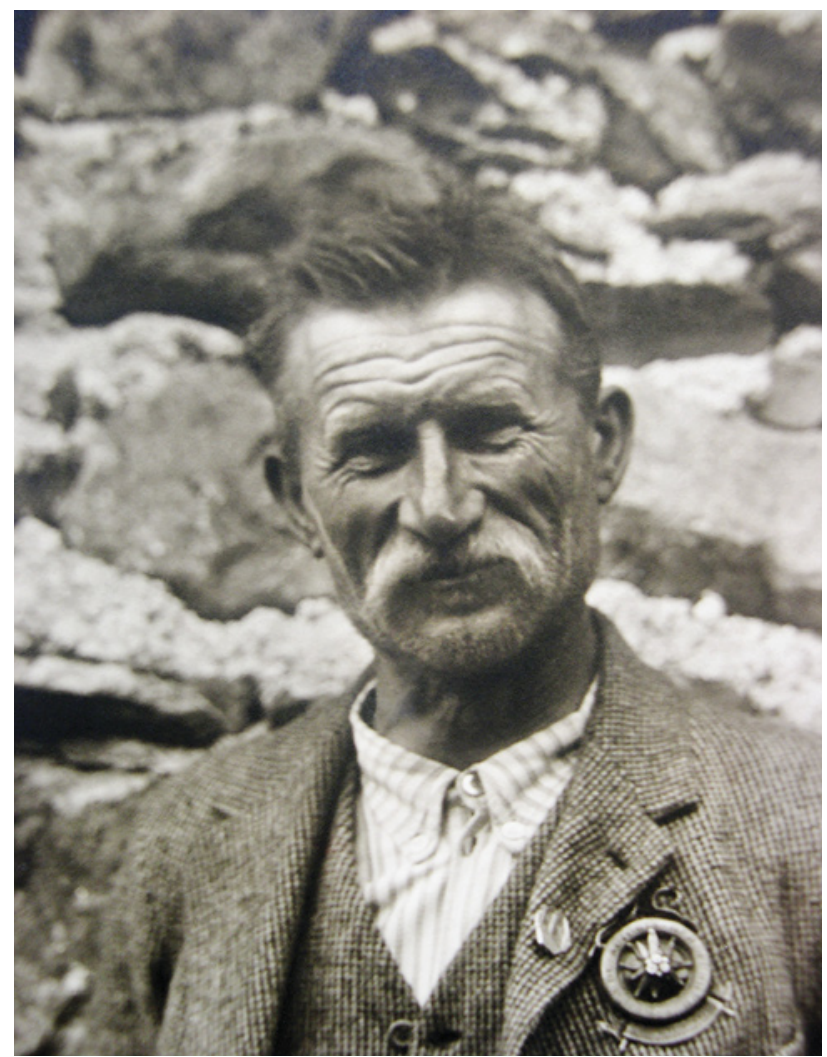

Figure 19. In the decades after Samuel Goldschmidt's death in 1871, only limited mining activities took place in Habachtal, including under lease to Alois Wurnitsch. His son, mountain guide Karl Wurnitsch (seen here), occasionally worked with his father in the area. Photo circa 1928; courtesy of E. Burgsteiner.

connections (figure 20). James Montague Leverson (1828-1908), the husband of Jeanette Brandeis's cousin Henrietta, had established a wholesale dia- mond business in London in 1870, which operated under the name "Leverson, Forster \& Co." from 1883 to 1906 and then as "James A. Forster \& Sons" until its formal dissolution in $1975 .{ }^{72}$ Leverson, Forster \& Co. also traded in high-value diamonds, such as the Imperial $^{73}$ and the Sancy, ${ }^{74}$ and held concessions for diamond mining in British Guiana. ${ }^{75}$ Principals and family members involved in various interconnected businesses-which over time extended to a subsidiary in Vienna, ${ }^{76}$ efforts to exploit the historical emerald mines in Egypt, ${ }^{77}$ and services as directors for a multiplicity of mining businesses ${ }^{78}$-included Leverson and his son Louis George Leverson (18601909) and James Amos Forster (1845-1919) and his son Allan Amos Forster (1874-1946).

After being contacted by Albert Brandeis, ${ }^{79}$ associates of Leverson, Forster \& Co. traveled to the Habachtal mine and may even have supervised preliminary mining or exploration as a preface to any decision to invest. ${ }^{80}$ They also apparently communicated the opportunity to another British diamond merchant, Anton Dunkels (1844-1911), also known as Anton Dunkelsbuhler or Anton Dunkelsbühler. His company was one of the largest wholesale diamond companies in London and one of the ten London-based companies forming the central diamond selling syndicate in $1890 .{ }^{81}$

In February 1896, Emerald Mines Limited was registered in London, with an address at Holborn Viaduct 29-30 identical to that of Leverson, Forster \& Co., to "acquire and work an emerald mine in Austria." James Amos Forster, Louis George Leverson, his cousin David Harry Leverson (1858-1935), Anton Dunkels, and Albert Brandeis were named as directors (see again figure 20). ${ }^{82}$ The stated capital was $£ 60,000$ (about US\$300,000 according to the ex-

\footnotetext{
${ }^{72}$ The London Gazette, May 11, 1883, p. 2517, January 9, 1891, p. 180, February 11, 1975, p. 1935; Grace's Guide to British Industrial History: Who's Who in Business, 1914.

${ }^{73}$ Spencer, 1911.

${ }^{74}$ Mitchell, 1984; Fort, 2012.

${ }^{75}$ British Guiana's mining industry, The Mining Journal, Railway and Commercial Gazette, Vol. 74, 1903, pp. 89, 185, 362, $418,625$.

${ }^{76}$ Kleine Mitteilungen, Journal der Goldschmiedekunst, 1903, p. 166; Neue Freie Presse, No. 13935, June 13, 1903, p. 20.

${ }^{77}$ Mac Allister, 1900; Streeter, 1903.

${ }^{78}$ Skinner, 1892.

${ }^{79}$ Die Zeit, Vol. 9, No. 2714, April 16, 1910, p. 5. Although certain texts suggest that Leverson, Forster \& Co. was alerted to the Habachtal opportunity by Alois Wurnitsch, this supposition is unsupported and contrary to logic. It is hardly conceivable that Wurnitsch, primarily a mineral collector and mountain guide, would have selected and contacted a London-based wholesale diamond merchant regarding Habachtal in the absence of any potential known connection to the firm. See Lahnsteiner, 1980; Hönigschmid, 1993.

${ }^{80}$ Leitmeier, 1938; Eberl, 1972; Hönigschmid, 1993. A visit to Bramberg by James Amos Forster was documented in 1894, and various materials prepared by Austrian authorities offer 1895 as the date mining commenced on behalf of Leverson, Forster \& Co.

${ }^{81}$ Lenzen, 1966.

${ }^{82}$ Skinner, 1899.
} 


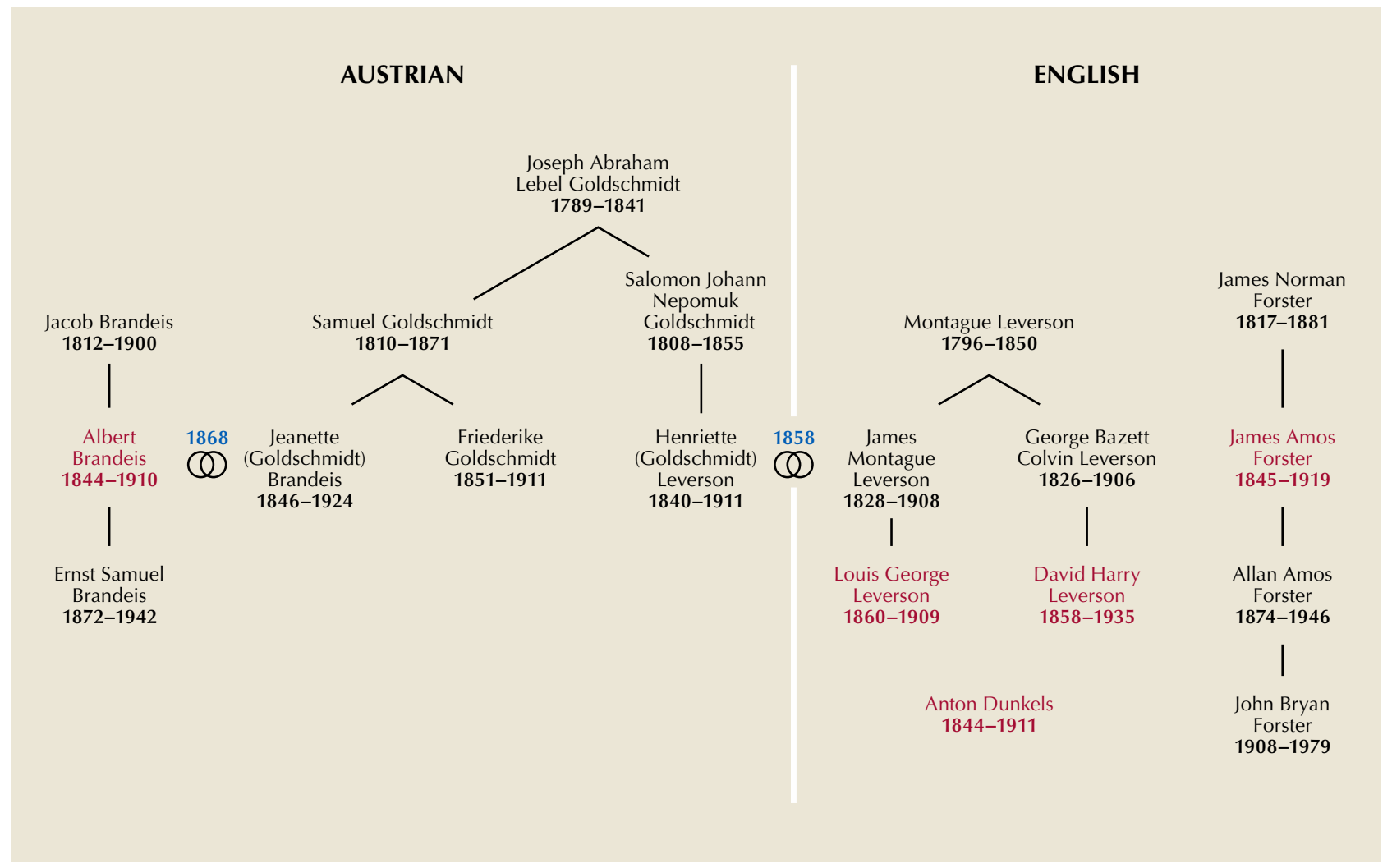

Figure 20. Relationships within and between the Austro-Hungarian Brandeis and Goldschmidt families and the English Leverson and Forster families. With regard to a key connecting link, Jeanette Brandeis, born Goldschmidt, and Henriette Leverson, born Goldschmidt, were cousins. The directors of Emerald Mines Limited are highlighted in red.

change rate for the era), divided in 60,000 shares of $£ 1$ each. The company purchased the mine in May 1896 from Albert and Jeanette Brandeis, with payment in the form of 10,220 shares $^{83}(17$ percent of the total number of shares). From that point, Albert Brandeis apparently played only a limited role in the mining venture, at least publicly.
Property Under Emerald Mines Limited and Controlled by Leverson, Forster \& Co. (1896-1906). Beginning in 1896, Emerald Mines Limited exploited the emerald deposit for several years. ${ }^{84}$ English and Austrian mining engineers were hired to guide operations. ${ }^{85}$ The years $1898-1901$ saw a succession involving Allan Amos Forster, ${ }^{86}$ the engineer

\footnotetext{
${ }^{83}$ Notarized contract between Albert Brandeis/Jeanette Brandeis and Emerald Mines Limited, May 11, 1896 (London) and May 20,1896 (Vienna), Mittersill land registry office, Archive of Salzburg Federal State; Habachtal emerald mine file, entry May 23, 1896, Mittersill land registry office; Lausecker, 1986. See also Die Zeit, Vol. 9, No. 2714, April 16, 1910, p. 5; Salzburger Volksblatt, Vol. 40, No. 87, April 19, 1910, pp. 4-5; Grundmann, 1979; Hönigschmid, 1993; Lewandowski, 1997. There is some inconsistency concerning the purchase price paid to the Brandeis family. A figure of 10,220 shares was presented in the original contract and by Grundmannn and Lewandowski; the 1,022 shares mentioned by Hönigschmid were presumably a typographical error. Conversely, a figure of 14,720 shares was given in a 1910 statement by Leslie Clarke during court proceedings in Berlin and reported in Die Zeit and Salzburger Volksblatt.

${ }^{84}$ File "Illegal mining in Bramberg," Akte Bergwesen XII B/1 1910, Emerald Mines Limited Aktiengesellschaft in London, unbefugter Bergbaubetrieb in Bramberg, 1902-1910, Archive of Salzburg Federal State (Land Salzburg, Landesarchiv), collecting documents from the period between 1902 and 1910 (hereinafter for convenience cited as File "Illegal mining in Bamberg," with dated reference to a particular document if available and generally without further details for facts repeated in several documents).

${ }^{85}$ For the 1899 season, Albert Brandeis offered the position as head of mining operations to the Austrian geologist Othenio Abel (1875-1946), but Abel declined the offer. See Ehrenberg, 1975.

${ }^{86}$ File "Illegal mining in Bramberg," document dated June 29, 1902; see also box B.
} 
Fothringham [Fotheringham?], ${ }^{87}$ the Cornish mine manager "Captain" John Ackerley Penhall (18421911; see figure B-1), ${ }^{88}$ and the Austrian mining engineer Paul Hartnigg (1839-1904). ${ }^{89}$

For the early years of English ownership, few details regarding the precise nature of the operations are available via original documentation, but more generalized information about the mining activities can be found..$^{90}$ The mine was worked underground in four galleries (see again figure 14) during the summer periods, extending four to five months from May or June to September or October, depending on weather conditions. ${ }^{91}$ Initially, $12-20$ miners were employed, later growing to 20-30 workers together with two mining engineers (figure 21). The possibility of building a cable railway to transport the emerald-bearing rocks down to the valley for washing and separating was considered..$^{92}$ Significant production was reported for the early years of the twentieth century, with annual numbers such as 68,000 carats one year and 32,000 carats of milky, cloudy stones plus 7,000 carats of greener emeralds another year..$^{93}$ The cleaner material was sent to India for cutting and brought to the international market as "Indian emerald." Nonetheless, it appears that very few stones of substantial size, quality, and value were found in the area. ${ }^{94}$

Despite these efforts, the ensuing years would bring a confluence of three factors that prevented Emerald Mines Limited from establishing a sustainable operation. First, as stated above, was a lack of profitability. Given the high percentage of unearthed material that was turbid and heavily included, financial benefit is doubtful. ${ }^{95}$ Second, access to the mine was dangerous, hampered by frequent heavy rock falls encompassing up to several hundred cubic meters in volume. E. Weinschenk, a geologist and petrologist who worked in the area from 1890 to 1894 , reported that he was unable to visit the occurrence to obtain study samples and that treacherous conditions had in general hindered mining in the region. ${ }^{96}$ Third, the company was beset by legal difficulties related to regulatory compliance, authorization, and permits necessary for the type of work being undertaken.

Early on, an exploration permit had been granted pursuant to the mining law in June 1893, with the term subsequently extended in June $1896 .{ }^{97}$ Allan Amos Forster, the lead mining engineer at the time, then declared in 1898 that the emeralds within the talc- and chlorite-schist were only a byproduct of exploration activities that sought minerals for which mining would be covered by the mining law. Forster's statement was accepted at that point without examination by the mining administration in Wels. ${ }^{98}$

The situation shifted in March 1902 when the Ministry of the Interior in Vienna began investigating the activities of Emerald Mines Limited in Habachtal. A letter was sent to the local state government in Salzburg questioning whether the English company had applied for appropriate permits for a foreign firm to work in Austria. The government was also concerned that the company had underreported its export values to avoid fees and taxes. ${ }^{99} \mathrm{As}$ the year progressed, Austrian authorities on both regional and local levels (in Salzburg, Zell am See, Wels, and Linz) became involved in the investigation. All ultimately concluded that the principal product was emeralds of gem quality, that the main interest of the company was emerald mining, and that the work was not related to exploration for other minerals. ${ }^{100}$ Moreover, with an invested capital of 35,000 Gulden (equivalent to 70,000 Kronen) and wages totaling 45,320 Kronen paid to miners from

${ }^{87}$ Eberl, 1972. The information provided by Lausecker (1986) and Grundmann (1991) about Allan Amos Forster and Fothringham was all based upon Eberl's publication, and no other reference was available to those authors. G. Grundmann, pers. comm., 2019; P. Lausecker, pers. comm., 2019.

${ }^{88}$ The Mining Journal, Railway and Commercial Gazette, Vol. 69, No. 3350, November 4, 1899, p. 1314; The Cornishman, February 25, 1904, p. 5, April 27, 1911, p. 4; The Mining Journal, Vol. 43, No. 3949, April 29, 1911, p. 442. During this era, mine "captains" were experienced miners who were responsible for organizing all underground activities at the mines. John Buckley, pers. comm., 2020. ${ }^{89}$ Salzburger Chronik für Stadt und Land, Vol. 37, No. 138, June 19, 1901, p. 4

${ }^{90}$ Lammer, 1897; Treptow, 1899.

${ }^{91}$ File "Illegal mining in Bramberg"; Salzburger Volksblatt, Vol. 29, No. 3, February 10, 1899, p. 2; Salzburger Chronik für Stadt und Land, Vol. 36, No. 236, October 16, 1900, p. 6; Vol. 37, No. 138, June 19, 1901, p. 4.

${ }^{92}$ Salzburger Volksblatt, Vol. 54, No. 174, July 31, 1924, p. 7.

${ }^{93}$ See The Mining World, Vol. 26, January 26, 1907, p. 111; Sterrett, 1907; Leitmeier, 1938; Eberl, 1972; Lausecker, 1986. The years given for these production figures vary from 1902 to 1904 in different references. However, due to the fact that the mine was closed from 1903 to 1905 , the information must necessarily refer to the mine yield for 1902 or before.

${ }^{94}$ Lausecker, 1986.

${ }^{95}$ See Leitmeier, 1938.

${ }^{96}$ Weinschenk, 1891, 1896; later visits were prevented by the English mine owners.

${ }^{97}$ File "Illegal mining in Bramberg," document dated June 29, 1902.

${ }^{98}$ File "Illegal mining in Bramberg," document dated August 7, 1902.

${ }^{99}$ File "Illegal mining in Bramberg," document dated March 10, 1902.

${ }^{100}$ File "Illegal mining in Bramberg." 

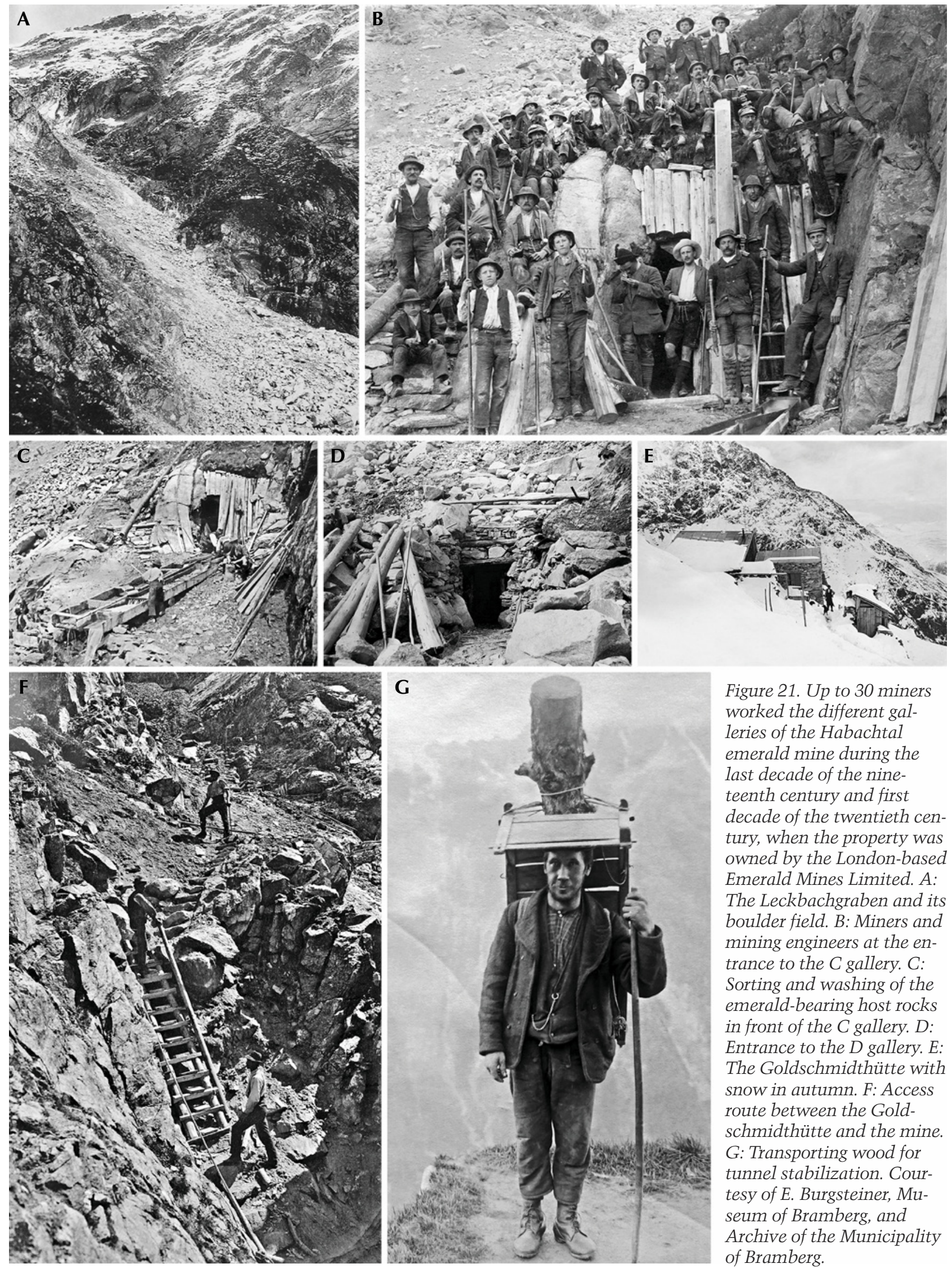

Figure 21. Up to 30 miners worked the different galleries of the Habachtal emerald mine during the last decade of the nineteenth century and first decade of the twentieth century, when the property was owned by the London-based Emerald Mines Limited. A: The Leckbachgraben and its boulder field. B: Miners and mining engineers at the entrance to the $C$ gallery. $C$ : Sorting and washing of the emerald-bearing host rocks in front of the $C$ gallery. $D$ : Entrance to the D gallery. E: The Goldschmidthütte with snow in autumn. F: Access route between the Goldschmidthütte and the mine. $G$ : Transporting wood for tunnel stabilization. Courtesy of E. Burgsteiner, Museum of Bramberg, and Archive of the Municipality of Bramberg. 
1896 to $1902,{ }^{101}$ the activity was deemed to be commercial in nature, exceeding any preliminary, noncommercial character that could still be related to early exploration and development. Consequently, rulings issued on June 29, 1902, from Zell am See and on February 8, 1903, from Salzburg declared the activity of Emerald Mines Limited in Habachtal illegal and directed the company to apply for any legally required permits and authorizations. The rulings in turn were sent to the firm's representative in Austria, the Vienna lawyer Dr. Ernst Bum (18551927). ${ }^{102}$ The miners were informed by mail in late May 1903 that operations would not resume for the upcoming summer season. ${ }^{103}$

${ }^{101}$ In 1910, a miner was paid 12 Kronen per week. Peter Nag/ v. Emerald Mines Limited, Bezirksgericht Mittersill, November 17, 1911, Mittersill land registry office. Extrapolating from this figure and assuming five months of work in the annual mining period, the resultant computation suggests payment of 250 Kronen for one miner per year, leading to an average workforce of approximately 26 miners for the seven years from 1896 to 1902 .

${ }^{102}$ File "Illegal mining in Bramberg."

${ }^{103}$ Salzburger Chronik für Stadt und Land, Vol. 39, No. 117, May 26, 1903, p. 3; see also Salzburger Volksblatt, Vol. 40, No. 87, April 19, 1910, pp. 4-5.

${ }^{104}$ File "Illegal mining in Bramberg"; Budwinskis Sammlung der Erkenntnisse des k.k. Verwaltungsgerichtshofes, 1906; Reif, 1908.

${ }^{105}$ See Thompson, 1906a; Die Zeit, Vol. 9, No. 2714, April 16, 1910, p. 5; Salzburger Volksblatt, Vol. 40, No. 87, April 19, 1910, pp. 4-5.

${ }^{106}$ Talking Machine News, July 1, 1905, p. 27.

${ }^{107}$ Who's Who in Mining and Metallurgy, London, publ. by The Mining Journal, 1910, p. 116

${ }^{108}$ Thompson, 1906a, b; Kunz, 1907; Die Zeit, Vol. 9, No. 2714, April 16, 1910, p. 5; Salzburger Volksblatt, Vol. 40, No. 87, April 19, 1910, pp. 4-5.

${ }^{109}$ The partnership between Louis George Leverson and James Amos Forster in Leverson, Forster \& Co., London, was dissolved the same year, in July 1906. The Vienna subsidiary of Leverson, Forster \& Co. was formally dissolved in early 1908, with a new company "James A. Forster \& Söhne" having already been established in Vienna in March 1907. The Times (London), Issue 38084, July 28, 1906, p. 17; Wiener Zeitung, No. 78, April 5, 1907, p. 23; Neue Freie Presse, No. 15687, April 23, 1908, p. 25.

${ }^{110}$ Skinner, 1907.

${ }^{111}$ South Bucks Standard, July 3, 1908, p. 2, July 17, 1908, p. 7; The Bucks Examiner, July 17, 1908, p. 6; The Times (London), Issue 40423, January 17, 1914, p. 3.

${ }^{112}$ Thompson, 1906b.

${ }^{113}$ See M.INST.M.M., 1908 (indicating that the mine was also worked in 1907); South Bucks Standard, August 14, 1908, p. 2 (quoting Leslie Clarke as stating in August 1908 that "the emerald mine in Austria had remained closed during the past year"); File "Illegal mining in Bramberg," document dated October 25, 1909 (concluding that Emerald Mines Limited was not actively mining in Habachtal by October 1909); Berliner Volkszeitung, Vol. 58, No. 230, May 20, 1910, p. 2 (quoting Leslie Clarke as stating that the mine "is closed since two years"); Die Zeit, Vol. 9, No. 2747, May 20, 1910, p. 4; Prager Tagblatt, Vol. 34, No. 139, May 22, 1910, p. 13; Leitmeier; 1938; Lewandowski, 2008 (mentioning that all activities were canceled in 1907).
Emerald Mines Limited appealed the rulings at the administrative level, but the company's arguments attempting to continue operations under the mining law were found baseless, and the previous decisions were upheld by the government on February 11,1905 . A petition was then filed with the Supreme Administrative Court in Vienna, resulting in a final decision against the company on June 28, 1906. ${ }^{104}$ The court affirmed that Emerald Mines Limited's production at Habachtal did not fall within the purview of the mining law and thus required compliance with the more general Trade, Commerce and Industry Regulation Act, the Austrian Decree for the Admission of Foreign JointStock Companies, and any associated regulatory requirements and permits.

Meanwhile, the London leadership of Emerald Mines Limited had opted not to reopen the Habachtal mine after the 1903 closure, ${ }^{105}$ instead seeking to sell the company.

\section{Property Under Emerald Mines Limited and Con-} trolled by Northern Mercantile Corporation Limited (1906-1911). Northern Mercantile Corporation Limited, a Manchester firm with an office in London, founded in 1904 and involved in the phonograph business, ${ }^{106}$ engaged Edmund Spargo \& Sons, a mining and commissions execution company from Liverpool, ${ }^{107}$ to investigate the mine in 1905. After receiving the report, Northern Mercantile Corporation Limited in 1906 purchased the shares of Emerald Mines Limited for $10 \%$ of the nominal value (i.e., £6,000, equivalent to $£ 0.1$ per share), thereby acquiring the principal asset, the Habachtal mine. ${ }^{108} \mathrm{~A}$ new board of directors was installed for Emerald Mines Limited, with only Albert Brandeis retaining his position and all members of the Leverson and Forster families ceasing any involvement. ${ }^{109}$ The group comprised Leslie Clarke, William King, F.K. MacMorran, and the aforementioned Albert Brandeis. ${ }^{110}$ Clarke, from the insurance industry, and King, previously a shipowner, maltster, and grain importer, were both to serve as mining brokers for Emerald Mines Limited. ${ }^{111}$

From that point, actual mining operations appear to have been sporadic at best, with more attention focused on financial markets. The mine was reopened in 1906, with one of Edmund Spargo's sons hired to provide oversight for a four-month period from July to October. ${ }^{12}$ Although documentation is ambiguous, certain statements suggest that mining activities stopped after the 1906 or 1907 seasons. ${ }^{113}$ 


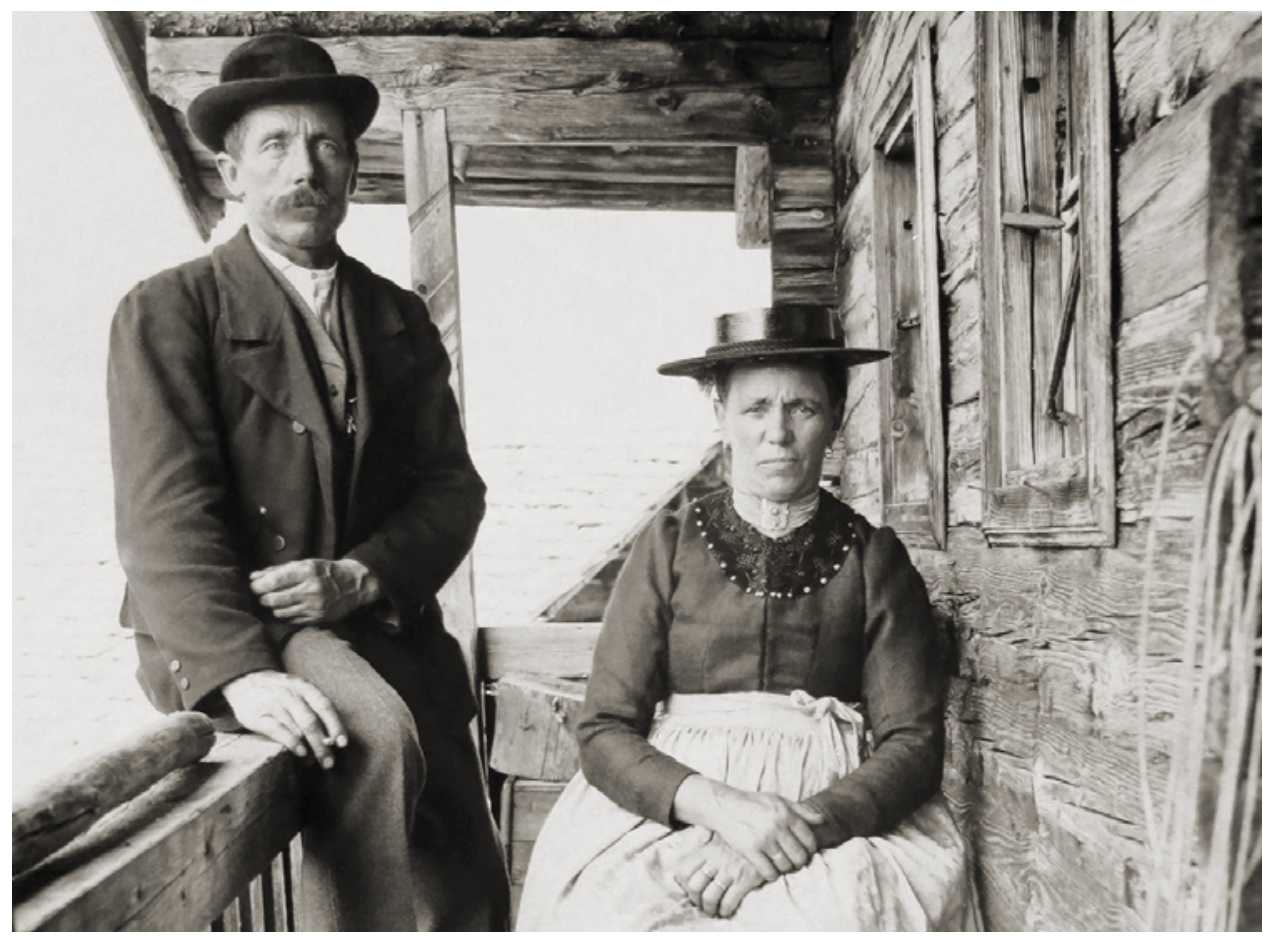

Figure 22. The final known action by Emerald Mines Limited that appears to have been taken with an underlying intent to recommence mining at Habachtal was the hiring of Peter Nagl (pictured here with his wife) in July and August 1910, but his wages were never paid. Members of the Nagl family were involved for decades in emerald mining at Habachtal. Courtesy of Museum of Bramberg.

A guard was posted for security purposes for a few years thereafter, but even that effort was eventually terminated. ${ }^{114}$ The only action that indicated a potential desire to recommence was the hiring of Peter Nagl (1860-1947; figure 22) from Bramberg in July and August 1910 for 12 Kronen a week, but his salary was never paid. ${ }^{115}$ Accounts suggesting that the English company blasted the main occurrence shortly before leaving, in order to hide the best material, ${ }^{116}$ find no documented support.

Mining operations at the now Manchester-based firm might also have been hampered by regulatory difficulties similar to those of its predecessor. The company applied to register as required for a foreign company in Austria, but the application was incomplete, and requests from the administration to complete the filing went unanswered. Even as late as the final available documentation dated February 1910, no authorization had been granted. ${ }^{117}$ The absence is corroborated by the Compass - Finanzielles Jahrbuch für Oesterreich-Ungarn, a financial and industrial handbook listing all national joint-stock companies and those foreign companies that were registered and had permission to work in the Austro-Hungarian Empire, which never included Emerald Mines Limited in any of its volumes from 1907 to $1914 .{ }^{118}$

Rather, the focus had turned to attracting investors. Materials such as an anonymous letter to the editor published by the Institution of Mining and Metallurgy in London, dated February 12, 1908, pre- sented a glowing picture of prospects. ${ }^{119}$ There, after discussing the emeralds originating from Muzo, Colombia, the letter professed:

It appears that almost the only other recognized emerald mine of importance at present in operation is located in the Salzburg Mountains in Austria, operated by an English company called "Emerald Mines, Limited," having their registered office at 37 Princess Street, Manchester. These mines are situated only 50 hours from London, near Bramberg railway station, at an altitude of from 7.000 to 8.000 feet above the sea. The mining rights extend over about 600 acres of specially selected ground, and are practically freehold. Up to 1906 over 200.000 carats had been produced in the previous ten working seasons. Of this quantity 56.000 carats were obtained during the last three months' development, ${ }^{120}$ from a depth of not exceeding 200 feet from the face of the mountain, so that the potentialities of the property are undoubted.

Each year as the workings develop in depth, the quality, colour, and size of the emeralds distinctly improve. The

\footnotetext{
${ }^{114}$ Koenigsberger, 1913; Leitmeier, 1938.

${ }^{115}$ Peter Nagl v. Emerald Mines Limited, Bezirksgericht Mittersill, November 17, 1911, Mittersill land registry office.

${ }^{116}$ See Lackner, undated.

${ }^{117}$ File "Illegal mining in Bramberg," documents dated September 30, 1909, February 12, 1910.

${ }^{118}$ See Compass - Finanzielles Jahrbuch für Oesterreich - Ungarn 1912, Vol. 45, Band II, Vienna, 1911, Compassverlag, Vienna, 1752 pp.; see also Präsidialbureau des k.k. Finanzministeriums, 1917

${ }^{119}$ M.INST.M.M., 1908.

${ }^{120}$ Most likely referring to the 1907 mining period.
} 


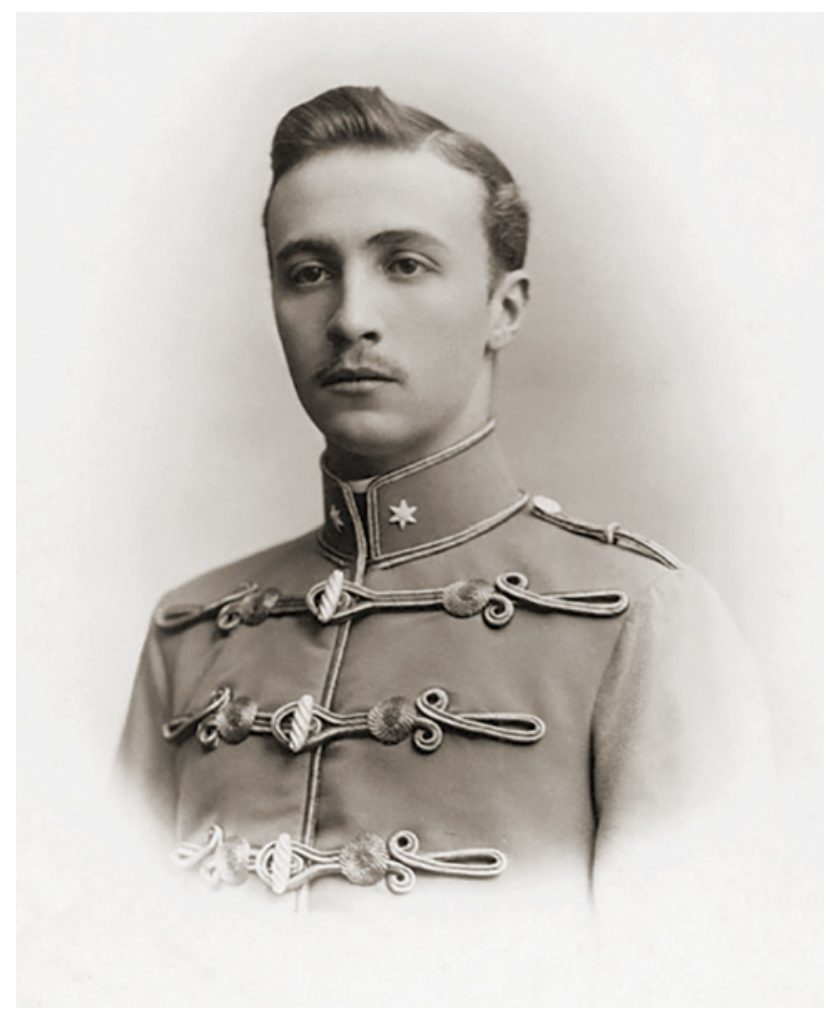

Figure 23. In the years 1909 and 1910, Prince Francis Joseph of Braganza became involved in a financial scandal during which he was offered, and purchased at vastly inflated values, shares of Emerald Mines Limited and "emerald" samples (later proven to be glass) said to originate from the Habachtal mine. The photo shows the young prince, circa 1900, in a uniform of the armed forces of the Austro-Hungarian Empire. Courtesy of Österreichische Nationalbibliothek, Wien.

deepest workings have so far only attained a depth of about one-fourth of that of the Muzo mines, and as the geological surroundings and emeraldiferous matrix are analogous to the Muzo mines, no greater assurance can possibly be desired as to the certainty of the highest quality of this precious gem being eventually obtained as the workings become prosecuted in depth. All elements of speculation may therefore be considered absent.

The Emerald Mines, Limited, have also acquired the freehold amethyst mines in the Schlusselstein, Commune of Bergheim, Alsace, ${ }^{121}$ and they were carefully investigated for the company by Mr. E.J. Spargo, M.F., F.G.S., of Liverpool, and Mr. William King, director of Emerald Mines, Limited, who is a well-known expert and connoisseur in precious stones and gems.

The general media similarly reported positive news, including the availability of 50,000 carats of rough emeralds of high value as well as thousands of shares being offered or sold by Clarke and King at values starting at a nominal £1 per share. ${ }^{122}$
Conversely, the financial statement from Emerald Mines Limited itself for the period ending December 31,1908 , reported "cash in hand and emeralds in stock £100."123 The lack of profitability was further reiterated by the fact that no dividend was ever paid to the shareholders of the company. ${ }^{124}$ In addition, while the entity Emerald Mines Limited continued to exist, an order was issued in March 1909 by the Manchester County Court to wind down Northern Mercantile Corporation Limited. ${ }^{125}$

Moreover, beyond even the puffery recounted above, certain transactions involving shares in and the leadership of Emerald Mines Limited erupted in financial scandal and litigation during the 1909 to 1911 period. Although details remain obscure, Prince Francis Joseph (Franz Josef) of Braganza (figure 23)126 was offered Emerald Mines Limited shares totaling $£ 200,000$ in purported value $(50,000$ shares at a value of $£ 4$ per share, in total equivalent to about 4.7 million Kronen, or US\$1 million at the time) by an impostor playing the role of a millionaire and member of the American Vanderbilt family. Likewise, 1,009 emeralds with a claimed value of $£ 125,000$ in total were offered to and purchased by the prince but later found to be glass. In the ensuing litigation, the impostor was sentenced to three years in prison in London in 1911. The precise roles of Clarke and King are uncertain, but they, too, were targeted. Clarke, who had been involved in several of the financial transactions, was imprisoned in Berlin in 1910 and formally sentenced to six months incarceration in 1911. King was initially arrested in London but was released shortly thereafter. ${ }^{127}$

\footnotetext{
${ }^{121}$ The referenced amethyst mines of Schlüsselstein were a longknown occurrence of agate and amethyst quartz, near Bergheim in the Alsace region of France, where amethyst was found in a vein as banded amethyst quartz. According to available descriptions, the material was merely ornamental and not facet-quality amethyst. Voltz, 1828; Benecke et al., 1900; Panzer, 1961.

${ }^{122}$ South Bucks Standard, July 3, 1908, p. 2, July 17, 1908, p. 7; The Bucks Examiner, July 17, 1908, p. 6.

${ }^{123}$ Skinner, 1910

${ }^{124}$ Die Zeit, Vol. 9, No. 2748, May 21, 1910, p. 6

${ }^{125}$ Supplement to the Manchester Courier, March 26, 1909, p. 4.

${ }^{126}$ Prince Francis Joseph (1879-1919) was an Austrian citizen, godchild of Franz Joseph I, Emperor of Austria, and grandson of the Portuguese King Miguel I, who reigned 1828-1834.

${ }^{127}$ See Neuigkeits Welt-Blatt, Vol. 37, No. 44, February 24, 1910, pp. 31-32; Neue Freie Presse, No. 16349, February 26, 1910, p. 9; Die Zeit, Vol. 9, No. 2714, April 16, 1910, p. 5, Vol. 9, No. 2747, May 20, 1910, p. 4; Neue Freie Presse, No. 16430, May 21, 1910, p. 4; Teplitz-Schönauer-Anzeiger, Vol. 50, No. 106, September 10, 1910, p. 5; Pester Lloyd, Vol. 58, No. 8, January 10, 1911, p. 1; The New York Times, February 16, 1911.
} 


\section{Box B: Mining Photos from the Era of Emerald Mines Limited}
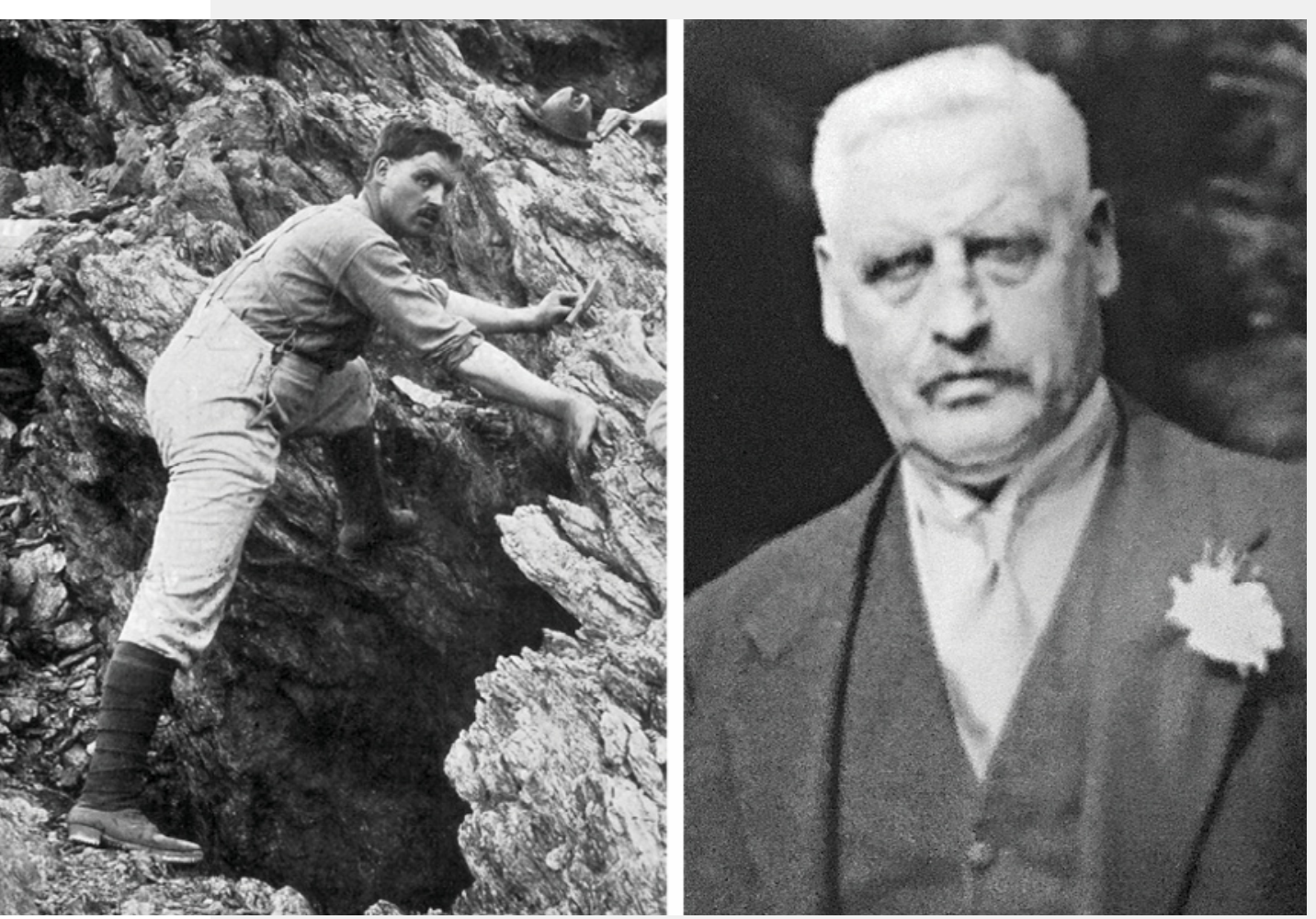

Figure B-1. Allan A. Forster led mining operations at Habachtal during several seasons in the last decade of the nineteenth century and first decade of the twentieth century. Left: Photo from the winter of 1899-1900, taken during the "Queen Cleopatra's Emerald Mines Expedition" in Egypt. See MacAlister (1900) and Claremont (1913); a similar photo with Forster and other members of the expedition is available online. ${ }^{1}$ Right: A 1935 photo from the Forster family album; courtesy of Maureen Mary Brett.

Operations on-site at Habachtal during the ownership of the English firm Emerald Mines Limited were overseen by a succession of English and Austrian mining engineers whose actual activities at the property are sparsely documented. Allan Amos Forster (1874-1946; figure B-1) filled that role at the outset, when the entity was controlled by Leverson, Forster \& Co., and "Captain" John Ackerley Penhall (1842-1911; figure B-2), for instance, was responsible for the 1899 season. Nonetheless, photos from the era can offer a degree of contemporaneous insight to the workings (figures B-3 and B-4; see also figure 21).

Interestingly, in a substantial number of mining, mineralogical, and gemological publications that endeavor to cover the Habachtal locality and its history, all depictions of the period appear to draw from a group of photos taken or owned by a single individual, Ernst Richard Horeis (born 1874), during the late nineteenth and early twentieth centuries, before 1903 .

Ernst was the son of Ferdinand Horeis, a JuwelenAgent (jewelry agent) in Vienna during the last decade of the nineteenth century through 1901 whose business was pursued by his younger son Emil Horeis (born 1877) from 1902 on. $^{2}$ While nothing links Ernst formally to his father's firm, he likely enjoyed some connection to the gemstone business through his father and, as a young man in his twenties, came into contact with Emerald Mines Limited. Although few details are ascertainable, Ernst seems to have done some work for Emerald Mines Limited that led to the company owing him 5,102 Kronen. A lien in such amount was recorded in his favor against the company at the Mittersill land registry office via an entry dated November 18, 1909, on the basis of a November 16, 1909 , judgment by the court in Salzburg. ${ }^{3}$ After his association with Emerald Mines Limited, Ernst apparently followed a different path, operating as a merchant.

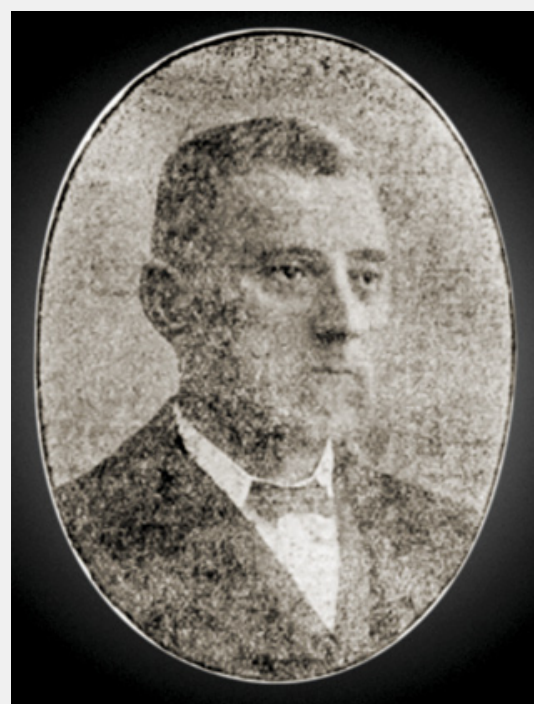

Figure B-2. "Captain" John Ackerley Penhall, an experienced miner from Cornwall, was responsible for emerald recovery on-site during the 1899 season at Habachtal. Photo from The Cornishman, December 1906. 
Linking Ernst to the photos involves a confluence of circumstantial evidence. At present, a significant number of these oft-seen photos are archived in three substantially similar collections, one of them housed at Bramberg $\mathrm{Mu}$ seum and the other two archived at the municipality of Bramberg. The collection at Bramberg Museum takes the form of an album. The photos in the album are undated and in general are labeled only with short notes such as "Bergwerk" (mine) or Habach. ${ }^{4}$ The album itself, however, incorporates illuminating notations memorializing its creation and its donation to the museum. To wit, a dedication reads, "Herrn Allan A. Forster zur Erinnerung an das schöne Habachthal" (Mr. Allan A. Forster to remember the beautiful Habachthal) and is signed by Ernst R. Horeis. The donation inscription on the same page offers, "To the Habachthal museum from the Son of the Englishman who worked this mine in the early 19 hundreds" and is signed "J.B. Forster 19-7-72."

John Bryan Forster (1908-1979; figure B-5) was the son of Allan Amos Forster, a relationship that clarifies the provenance of the album. The annotations together also verify the association of Ernst Richard Horeis with the early period when Emerald Mines Limited was under the control of Leverson, Forster \& Co. and his close connection with the first mining engineer and son of James Amos Forster, one of the directors of Emerald Mines Limited. Nonetheless, the precise nature of Ernst's activities for the company remains obscure. The amount of more than 5,000 Kronen eventually owed to him per the lien recorded would have equated to the annual compensation for approximately 25 workers during the 1896 to 1902 period, when Emerald Mines Limited was under the control of Leverson, Forster \& Co. That amount was likely not merely the annual salary of a single individual, even if he worked as a director, ${ }^{5}$ presumably signaling a multi-year association. John Bryan himself would follow in the foot-

\footnotetext{
${ }^{1}$ https://www.gettyimages.de/detail/nachrichtenfoto/chipping-out-anemerald-this-image-shows-dr-grote-with-nachrichtenfoto/980049796 ${ }^{2}$ Archive of the City of Vienna (Wiener Stadt- und Landesarchiv), pers. comm., 2020; Lehmann's Allgemeiner Wohnungs-Anzeiger nebst Handels- und Gewerbe-Adressbuch für die k.k. Reichs-Haupt- und Residenzstadt Wien und Umgebung, Volumes 32-52 (1890-1910).

${ }^{3}$ Archive of Salzburg Federal State, pers. comm., 2020. Specifics are minimal because the original file for the Salzburg litigation was not preserved.

${ }^{4}$ E. Burgsteiner, pers. comm., 2019.

${ }^{5}$ Eberl $(1972)$ mentioned that Emil Horeis, the younger of the two brothers, worked for Emerald Mines Limited as a director until 1904, but available facts suggest a potential mistaking of the two brothers. Lausecker (1986) and Grundmann (1991) repeated this based solely on what had been stated by Eberl, without recourse to further documentation. P. Lausecker, pers. comm., 2019; G. Grundmann, pers. comm., 2019.

${ }^{6}$ The London Gazette, February 11, 1975, p. 1935; Maureen Mary Brett, daughter of John Bryan Forster, pers. comm., 2020.
}

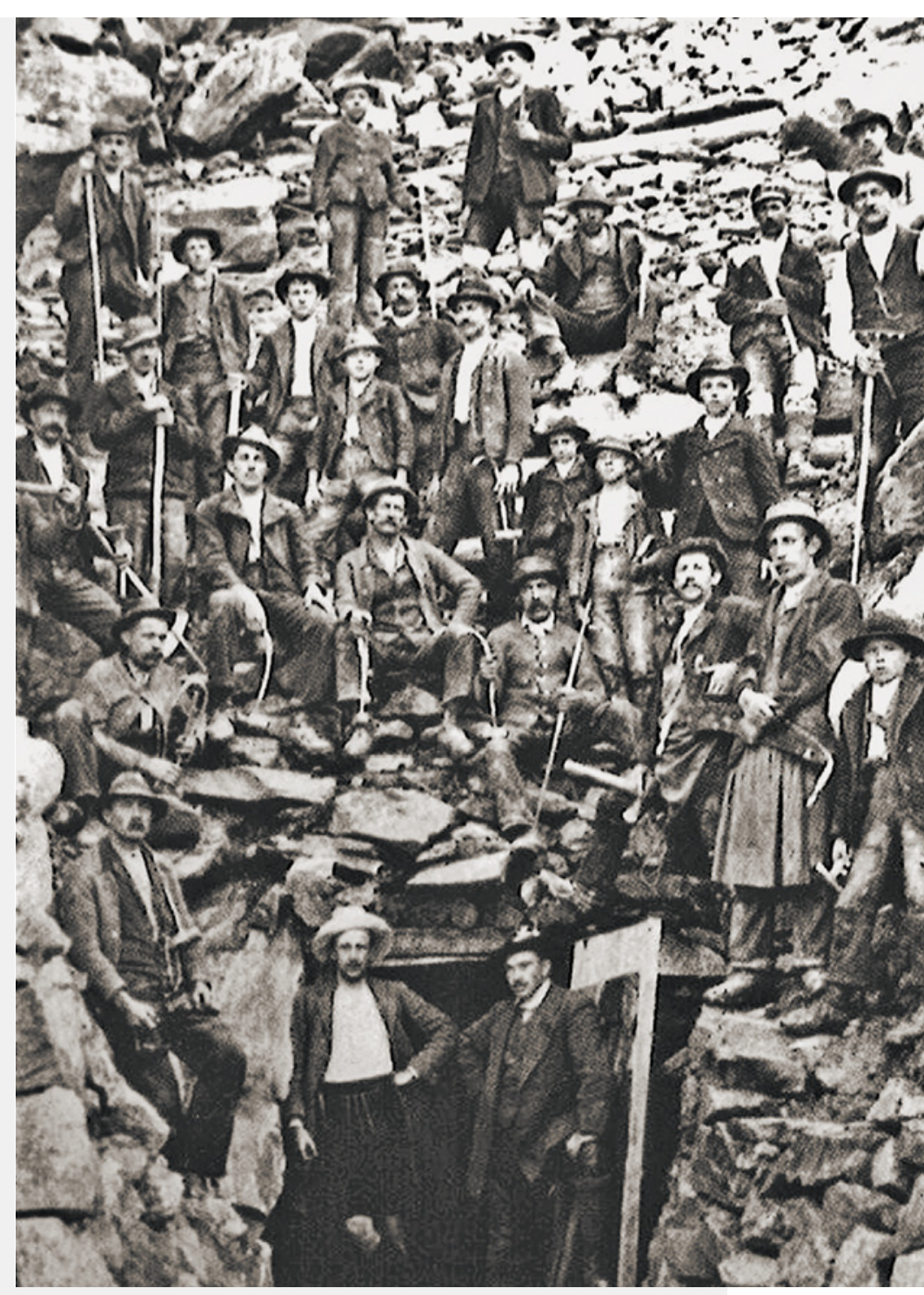

Figure B-3. Up to 30 miners worked the different galleries of the Habachtal mine in the late nineteenth and early twentieth centuries, when the property was owned by the London-based Emerald Mines Limited. Here the miners and mining engineers are at the entrance to the D gallery. Courtesy of P. Lausecker.

steps of his father and grandfather as a precious stones merchant and the last owner of James A. Forster \& Sons (the name under which the company operated after 1906), which closed in 1975 following his retirement. ${ }^{6}$

Corroboration of the linkage of the photos to the Habachtal mine generally and to the name Horeis more particularly is offered by the two collections alluded to above, archived with municipality of Bramberg. One was in the possession of the descendants of Peter Staudt, who purchased half of the mine from his brother Anton Hager in 1920 (see part II of this article in the Spring 2022 issue), 


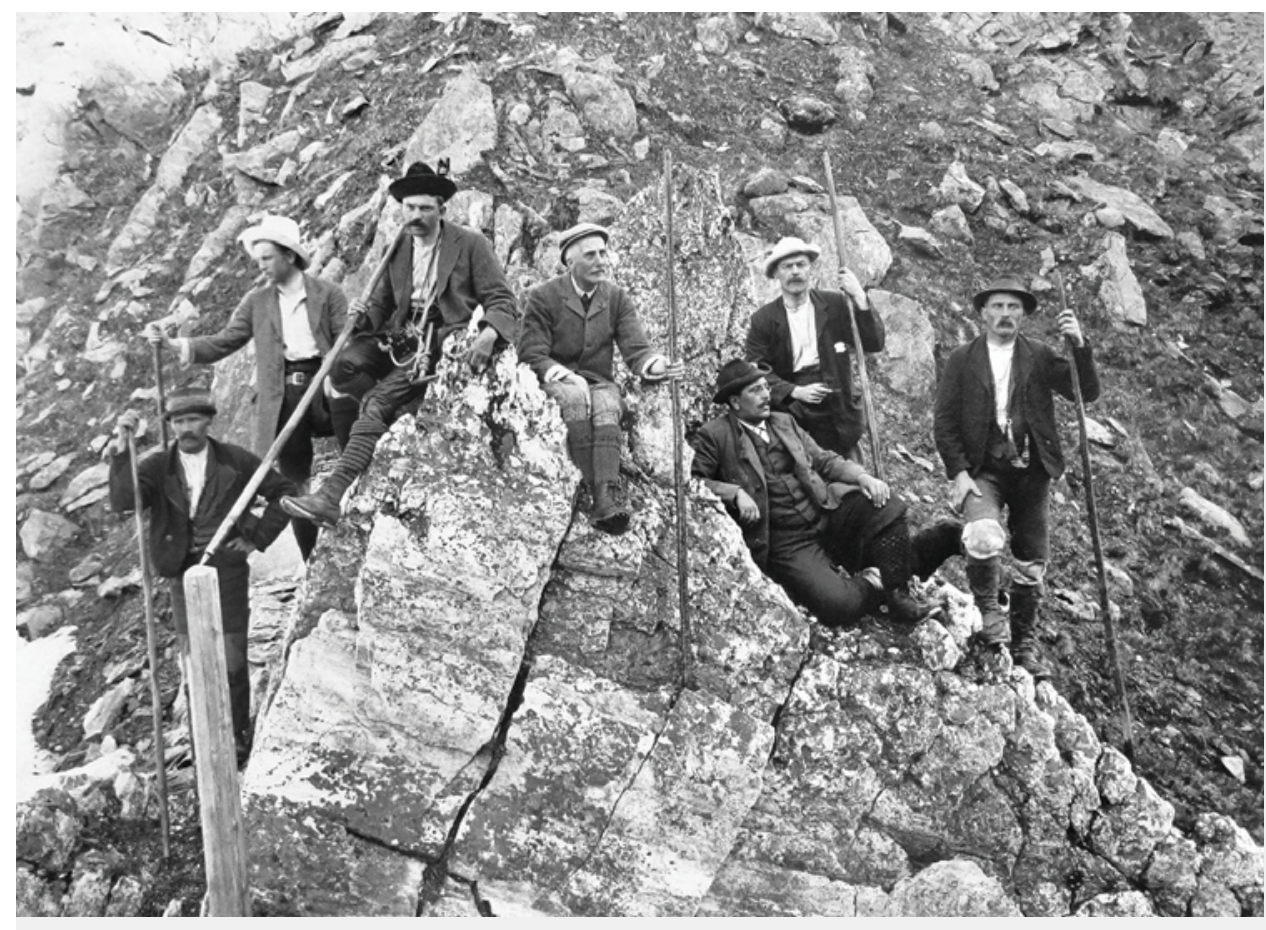

Figure B-4. Miners and mining engineers at Habachtal during the era when the English firm Emerald Mines Limited held the property in the late 1800 s and early 1900s. The man in the center resembles the English miner "Captain" John Ackerley Penhall (see figure B-2). Archive of the Municipality of Bramberg.

and was donated a few years ago to the municipality. ${ }^{7}$ The other was provided to the municipality accompanied by a note indicating that images were photographed by "Horeis" from "1898-1902". ${ }^{8}$ This collection had initially been given by the photographer, also characterized without documentary support as a director of the Habachtal mine, to the gem cutter Drazky from Vienna. ${ }^{9}$

The dating referenced for the photos is also a logical range and more consistent with the known circumstances than the various dates between 1902 and 1908 often assigned by the multiple publications reusing the photos (with different years even being quoted for the same photo). As explained in the main text, mining activities ceased in 1903 (following the 1902 season) after a series of more or less productive years, and no further work took place on-site until after the shares of Emerald Mines Limited were transferred in 1906 to the Northern Mercantile Corporation Limited. Meanwhile, all members of the Leverson and Forster families ceased involvement with the mine at the time of the transition.

Consequently, the weight of evidence indicates that the photos in the album and the collections at the municipality of Bramberg (as well as similar collections owned by other individuals) were taken prior to 1903 and photographed or owned by Ernst Richard Horeis. The images thus represent the situation at the end of the nineteenth century or beginning of the twentieth century.

${ }^{7}$ Brigitte Leitermann, granddaughter of Peter Staudt, pers. comm., 2020.

${ }^{8}$ Materials left by R. Eberl at his death, Archive of the Municipality of Bramberg.

9'Eberl, 1972.
Figure B-5. John Bryan Forster inherited from his father, Allan Amos Forster, an album presented by Ernst Richard Horeis that contained photos from the Habachtal at the end of the nineteenth century or beginning of the twentieth century. The younger Forster, shown here, donated the album to Bramberg Museum in 1972. Photo from the mid-1970s; courtesy of Maureen Mary Brett.

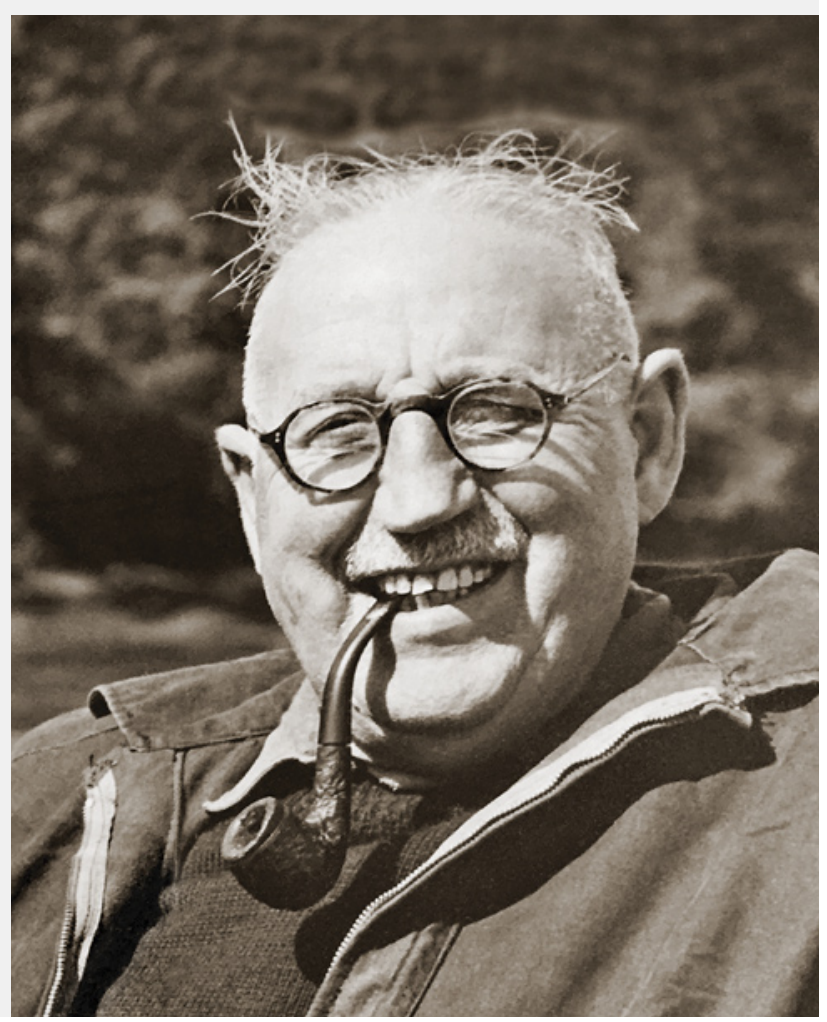




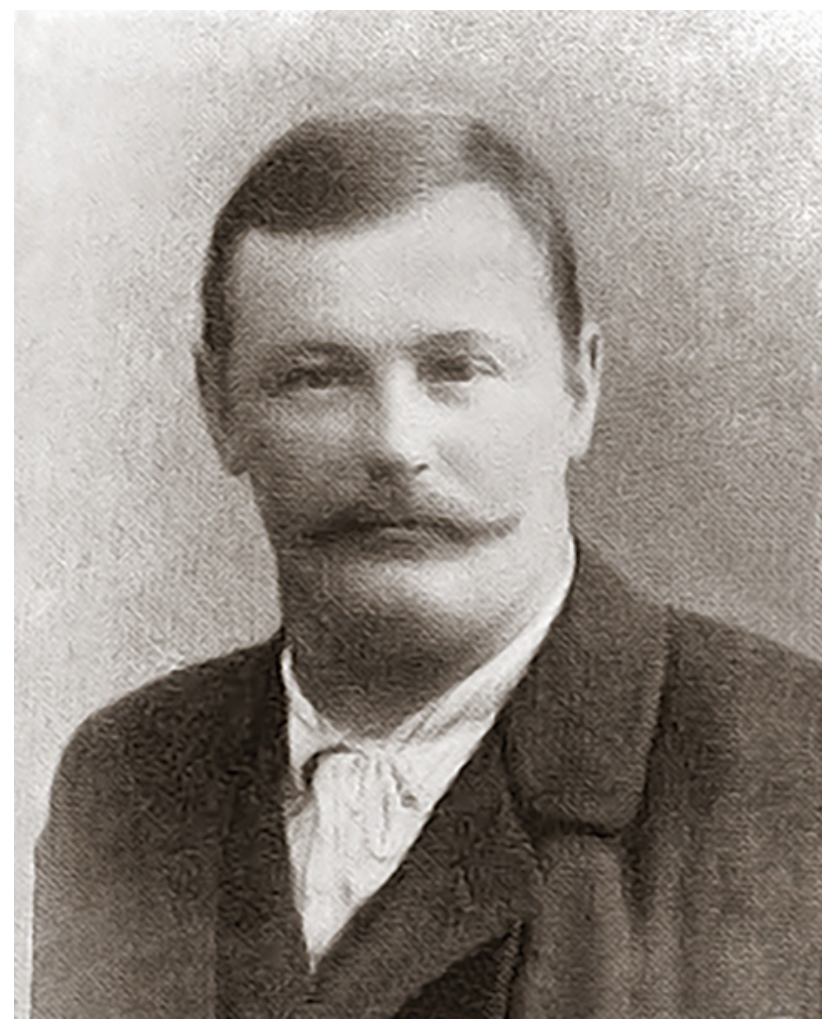

Figure 24. In 1913, the Habachtal emerald property was bought by Peter Meilinger (pictured), at that time mayor of the municipality of Bramberg, together with councilmen Alois Kaserer and Johann Blaikner. Undated photo; courtesy of E. Burgsteiner.

Transfers Back to Austrian Ownership (1911-1914). By the close of the first decade of the twentieth century, the liabilities of Emerald Mines Limited owed in Austria, including debts to certain individuals such as Ernst Reichard Horeis from Vienna (born 1874; see box B), to the municipality of Bramberg, and to various governmental authorities for taxes and fees, had accumulated to 41,658 Kronen (approximately US $\$ 8,500$ according to the exchange rate at the time). Repeated demands for payment were ignored, and, consequently, the tax administration in Mittersill initiated a foreclosure action in September 1911. ${ }^{128}$

In conjunction with these efforts, a report was prepared for the Mittersill court in August 1912 by the geologist Dr. Theodor Ohnesorge of the k.k. geologischen Reichsanstalt, Vienna, who had previously worked in the Pinzgau. ${ }^{129}$ The report described the geology of the area and characterized the rocks crossed by the four underground galleries (designated A, B, C, and D) used during the English ownership (see again figure 14). The two lower galleries, A and $\mathrm{B}$, did not cross the emerald-bearing biotite schist, referred to as Smaragdmutter (emerald mother), and were useless. The two upper galleries, C and D, crossed an emerald-bearing schist that reached a thickness of up to $2 \mathrm{~m}$ in the part accessible through the $\mathrm{D}$ gallery. However, the adit to the $\mathrm{D}$ gallery was blocked by rock masses and needed to be reopened. Taking into account the low quality of the emeralds for faceting purposes, Ohnesorge calculated a value for the property of 8,000 Kronen.

Meanwhile, as the legal machinations moved forward, the emerald deposit apparently remained of interest to the Brandeis family. In 1912, the chemical engineer Ernst Brandeis applied for and obtained an exploration permit for the area of the Duchy of Salzburg, but there is no evidence of any practical outcome. ${ }^{130}$

Insofar as the foreclosure sale proceedings initiated in 1911 failed to attract buyers, ownership of the property was transferred to the municipality of Bramberg in January 1913. ${ }^{131}$ At the end of the year, in December, the property was purchased by a group of farmers and municipal leaders from Bramberg, namely Alois Kaserer, Johann Blaikner, and Peter Meilinger (figure 24). ${ }^{132}$ The price was 6,000 Kronen, and ownership was formally transferred in February 1914. ${ }^{133}$ It appears that no systematic emerald mining

\footnotetext{
${ }^{128}$ Kleine Volkszeitung, Vol. 81, No. 317, November 16, 1935, p. 4; Lewandowski, 1997.

${ }^{129}$ Ohnesorge, T., Geologisches Gutachten über den Smaragdbergbau im Habachtale, 4 pp., Archive of the Geologische Bundesanstalt, Vienna. Copy, undated, 6 pp., Archive of the Municipality of Bramberg. Dr. Theodor Ohnesorge (1876-1952), a geologist at the k.k. geologischen Reichsanstalt, later the Geologische Bundesanstalt, in Vienna from 1904 to 1925, worked for many years in the Alps of Salzburg and Tyrol. See Wiener Zeitung, No. 52, March 3, 1907, p. 6.

${ }^{130}$ Die Zeit, Vol. 11, No. 3367, February 9, 1912, p. 13.

${ }^{131} \mathrm{Habachtal}$ emerald mine file, entry January 16, 1913, Mittersill land registry office; Kleine Volkszeitung, Vol. 81, No. 317, November 16, 1935, p. 4; Lewandowski, 1997. Later, Emerald Mines Limited was formally dissolved in the UK in 1921. Skinner, 1922.

${ }^{132}$ Notarized contract between the municipality of Bramberg and Alois Kaserer/Johann Blaikner/Peter Meilinger, December 6, 1913, Mittersill land registry office, Archive of Salzburg Federal State; Habachtal emerald mine file, entry February 14, 1914, Mittersill land registry office. At the time of the 1913 transaction, Peter Meilinger (1879-1936) was serving as the mayor of Bramberg, and Alois Kaserer (1866-1930) and Johann Blaikner (1855-1933) were both serving as councilmen for municipality. Each of the latter two had previously been the mayor as well, from 1900 to 1906 and 1906 to 1908 , respectively. Meilinger's term in the position extended from 1911 to 1919. Volksfreund, Vol. 22, No. 1, January 7, 1911, p. 4; Josef Seifriedsberger, pers. comm., 2020.

${ }^{133}$ Salzburger Volksblatt, Vol. 58, No. 240, October 18, 1928, p. 7; Lausecker, 1986; Lewandowski, 1997; see also Aitkens, 1931; von
} Arx, 1984; Grundmann, 1991; Exel, 1993. 
was undertaken by the three new owners, either in 1914 or in the first years of World War I.

Outlook. The second part of the article will cover various mining activities between 1916 and the end of the 1940s. After a relatively stable period between 1920 and 1927 under a German and an Austrian owner, the mine was sold to a Swiss company that did not have the financial resources for active mining operations. A conflict over control of the mine started in 1932, which ended in another ownership transfer. Further mining was then performed under another Swiss entity until 1939. Immediately after World War II, small-scale mining resumed.

\section{REFERENCES}

Aitkens I. (1931) Emeralds. U.S. Bureau of Mines Information Circular $6459,18 \mathrm{pp}$.

Arenstein J. (1862) Austria at the International Exhibition of 1862. Imperial Royal Court and State Printing Office, Vienna, p. 12.

Aulitzky H. (1973) Hochwasser, Muren, Lawinen: Information über Wasserwirtschaft und Katastrophenschutz, 2nd ed. Bundesministerium für Land- und Forstwirtschaft, Vienna, $272 \mathrm{pp}$.

Benecke E.W., Bücking H., Schumacher E., van Werveke L. (1900) Geologischer Führer durch das Elsass. Gebrüder Borntraeger, Berlin, 461 pp.

Brückmann F.E. (1727) Magnalia Dei in Locis Subterraneis Oder Unterirdische Schatz-Cammer Aller Königreiche und Länder, in Ausführlicher Beschreibung Aller, mehr als MDC. Bergwercke Durch Alle vier Welt-Theile. Braunschweig, Germany, $368 \mathrm{pp}$.

— (1730) Magnalia Dei in Locis Subterraneis Oder Unterirdische Schatz-Cammer Aller Königreiche und Länder, IIter Theil, in Ausführlicher Beschreibung Aller, mehr als MDC. Bergwercke Durch Alle vier Welt-Theile. Wolfenbüttel, Germany, $1136 \mathrm{pp}$.

Budwinskis Sammlung der Erkenntnisse des k.k. Verwaltungsgerichtshofes, Vol. 30 (1906) Manzschen k.u.k. Hof-Verlags- u. Univers.-Buchhandlung, Vienna, pp. 831-832.

Calligaro T., Dran J.-C., Poirot J.-P., Querré G., Salomon J., Zwaan J.C. (2000) PIXE/PIGE characterisation of emeralds using an external micro-beam. Nuclear Instruments and Methods in Physics Research Section B: Beam Interactions with Materials and Atoms, Vol. 161-163, pp. 769-774, http://dx.doi.org/10.1016/S0168583X(99)00974-X

Claremont L. (1913) Prehistoric emerald mines. Knowledge Magazine, Vol. 36, pp. 124-127.

Dopsch H., Lang J. (2012) Salzburg und Berchtesgaden. Zur Entstehung geistlicher Länder im Ostalpenraum. Österreich in Geschichte und Literatur mit Geographie, Vol. 56, No. 4, pp. 323-343.

Dückher F. (1666) Saltzburgische Chronica. Johann Baptist Mayr, Salzburg, Austria, $361 \mathrm{pp}$. and accompanying map.

Eberl R. (1972) Smaragde - Segen und Fluch. Publ. by the author, Vienna, $105 \mathrm{pp}$

Ehrenberg K. (1975). Othenio Abels Lebensweg. Unter Benützung autobiographischer Aufzeichnungen. Publ. by the authorÖsterreichische Hochschülerschaft, Vienna, 162 pp.

Ertl R.F. (1982) Smaragd - Namen, Mythos, Fund- u. Entdeckungs- geschichte. Die Eisenblüte N.F., Vol. 3, No. 6, pp. 3-11.

Exel R. (1993) Die Mineralien und Erzlagerstätten Österreichs. Publ. by the author, Vienna, $447 \mathrm{pp}$.

Fabri J.E. (1786) Geographie für alle Stände. Volume 1, Issue 1. Schwickertschen Verlage, Leipzig, p. 396.

Flurl M. (1792) Beschreibung der Gebirge von Baiern und der oberen Pfalz. Joseph Lentner, Munich, 642 pp.

Feitzinger G., Günther W., Brunner A. (1998) Bergbau- und Hüttenaltstandorte im Bundesland Salzburg. Land Salzburg, Hausdruckerei, $214 \mathrm{pp}$.

Fort A. (2012) Nancy: The Story of Lady Astor. Random House, London, p. 336.

Freed J.B. (1999) Landesbildung, Herrschaftsausbau und Ministerialität. In H. Dopsch et al., Eds., 1200 Jahre Erzbistum Salzburg: Die älteste Metropole im deutschen Sprachraum. Gesellschaft für Salzburger Landeskunde, Salzburg, Austria, pp. 87-102.

Frischholz J. (1821) Über den Salzburger Smaragd. Neue Jahrbücher der Berg- und Hüttenkunde, Vol. 4, pp. 382-385.

Fugger E. (1878) Die Mineralien des Herzogthumes Salzburg. Im Selbstverlage des Verfassers, Salzburg, Austria, 124 pp.

- (1881) Die Bergbaue des Herzogthumes Salzburg. Vierzehnter Jahres-Bericht der K.K. Ober-Realschule in Salzburg. K.K. Ober-Realschule, Salzburg, pp. 1-24.

Fürnohr W. (1952) Das Patriziat der Freien Reichsstadt Regensburg zur Zeit des Immerwährenden Reichstags. In Verhandlungen des Historischen Vereins für Oberpfalz und Regensburg, Vol. 93, pp. 153-308.

Gaugusch G. (2011) Wer einmal war: Das jüdische Grossbürgertum Wiens 1800-1938, A-K. Amalthea Verlag, Vienna, 1649 pp.

Giuliani G., Chaussidon M., Schubnel H.-J., Piat D.H., RollionBard C., France-Lanord C., Giard D., de Narvaez D., Rondeau B. (2000) Oxygen isotopes and emerald trade routes since antiquity. Science, Vol. 287, No. 5453, pp. 631-633, http://dx.doi.org/10.1126/science.287.5453.631

Gonthier E. (1998) Les représentations symboliques de quelques émeraudes célèbres de 1'histoire. In D. Giard, Ed., L'émeraude. Association Française de Gemmologie, Paris, pp. 27-32.

Gruber F., Ludwig K.-H. (1982) Salzburger Bergbaugeschichte. Ein Überblick. Universitätsverlag Anton Pustet, Salzburg-Munich, $141 \mathrm{pp}$.

Grundmann G. (1979) Geologisch-petrologische Untersuchung der Smaragd-führenden Gesteinsserien der Leckbachscharte, Habachtal (Land Salzburg, Österreich). Thesis, Technische Uni- 
versität Berlin, pp. 20-24.

(1991) Smaragd - Grünes Feuer unterm Eis. extraLapis No. 1. Christian Weise Verlag, Munich, 93 pp.

Grundmann G., Koller F. (2003) Exkursion: Das Smaragdbergwerk im Habachtal, Land Salzburg, Österreich. Mitteilungen der Österreichischen Mineralogischen Gesellschaft, Vol. 148, pp. 317-343.

Gübelin E.J. (1956a) Emerald from Habachtal. Journal of Gemmology, Vol. 5, No. 7, pp. 342-361.

(1956b) The emerald from Habachtal. $G \uplus G$, Vol. 8, No. 10, pp. 295-309.

Günther W. (1994) Entwicklung des Berg- und Hüttenwesens und ihre wirtschaftliche und kulturelle Bedeutung. Diverse Verlagsschriften des Naturhistorischen Museums Wien, Vol. 13, pp. 113-225.

Günther W., Lewandowski K. (2002) Montanbehörden und Montaninstitutionen in Salzburg. Mitteilungen der Gesellschaft für Salzburger Landeskunde, Vol. 142, pp. 267-290.

Haberer L., Zechner F. (1884) Handbuch des österreichischen Bergrechtes auf Grund des allgemeinen Berggesetzes vom 23. Mai 1854. Manz'sche k.k. Hof-Verlags- und Universitätsbuchhandlung, Vienna, $457 \mathrm{pp}$.

Hagn K. (2019) Das "grüne Gold" aus den Tauern. Salzburger Nachrichten, Juwelen \& Uhren Weihnachtsjournal, pp. 40-43.

Haidinger W. (1861) Ansprache des Direktors. Jahrbuch der k.k. geologischen Reichsanstalt, Vol. 12, No. 1, p. 95.

Hanke H. (1938) Smaragdbergbau in den Hohen Tauern. Neue Zürcher Zeitung, Vol. 159, No. 286, p. 5.

(1939) Das einzige Smaragdbergwerk Europas. Das Werk, Monatsschrift der "Vereinigte Stahlwerke Aktiengesellschaft," Vol. 19, pp. 195-198.

(1944) Smaragde aus dem Habachtal. Salzburger Volksbote, Vol. 1944, No. 13, p. 4.

_ (1958) Smaragde aus dem Habachtal. Kosmos, Vol. 54, No. 8, pp. 320-324.

Hansen J.M. (2009) On the origin of natural history: Steno's modern, but forgotten philosophy of science. Bulletin of the Geological Society of Denmark, Vol. 57, pp. 1-24.

Hauschke N. (2019) Niels Stensen (1638-1686) - Ein Europäer der Barockzeit als Wegbereiter der Geologie, Paläontologie und Mineralogie. Mit bisherigen Würdigungen in der Philatelie. Der Aufschluss, Vol. 70, No. 6, pp. 358-374.

Haüy R.-J. (1804) Lehrbuch der Mineralogie. Part II. C.H. Reclam, Paris and Leipzig, $723 \mathrm{pp}$.

Hönigschmid H. (1993) Bramberg am Wildkogel. Gemeinde Bramberg, Bramberg am Wildkogel, $656 \mathrm{pp}$.

Jacob K.-H. (2006) Über den Flussspatbergbau in der Oberpfalz von 1877 bis 1987. Bergbau, 12/2006, pp. 549-556.

Jameson R. (1820) A System of Mineralogy, in which Minerals Are Arranged According to the Natural History Method. 3rd ed., Vol. I. Archibald Constable \& Co., Edinburgh, 405 pp.

Kardel T., Maquet P., Eds. (2013) Nicolaus Steno: Biography and Original Papers of a 17th Century Scientist. Springer, Heidelberg, Germany, 739 pp.

Klaproth H., Wolff F. (1810) Chemisches Wörterbuch, Vol. 5. In der Vossischen Buchhandlung, Berlin, 833 pp.

Koenigsberger J. (1913) Versuch einer Einteilung der ostalpinen Minerallagerstätten. Zeitschrift für Kristallographie und Mineralogie, Vol. 52, No. 2, pp. 151-174.

Kržic A., Smit Ž., Fajfar H., Dolenec M., Cinc Juhant B., Jeršek M. (2013) The origin of emeralds embedded in archaeological artefacts in Slovenia. Geologija, Vol. 56, No. 1, pp. 29-45, http://dx.doi.org/10.5474/geologija.2013.003

Kunz G.F. (1907) Precious stones. In The Mineral Industry - Its Statistics, Technology and Trade during 1906. Vol. 15, Hill Publishing Co., New York and London, pp. 665-673.

Lackner N.B.G. (n.d.) Emeralds from Habachtal, Austria. Antique Jewelry University, https://www.langantiques.com/university/emeralds-from-habachtal-austria
Lahnsteiner J. (1959) Die Seninger-Erbabhandlung von 1732. Mitteilungen der Gesellschaft für Salzburger Landeskunde, Vol. 99, pp. 111-138.

(1980) Oberpinzgau von Krimml bis Kaprun, 3rd ed. Hollersbach, Salzburg, Austria, publ. by A. and M. Lahnsteiner, $723 \mathrm{pp}$.

Lammer G.E. (1897) Vergessene Tauernthäler. Mittheilungen des Deutschen und Österreichischen Alpenvereins, Vol. 23, No. 3 , pp. 25-26, and No. 4, pp. 37-38.

Lausecker P. (1986) Smaragdfundstelle Habachtal - Geschichte, Geologie, Bergbau. Hof/Saale, PHL-Verlag, 104 pp.

Lehmann F.W.P. (1879) Die Wildbäche der Alpen. Eine Darstellung ihrer Ursachen, Verheerungen und Bekämpfung (Theil 1). E. Gutsmann, Breslau, 32 pp.

Lehner J. (1669) Balnei Abacensis in Bavaria inferior nova descriptio. Das ist: Kurze Beschreibung des Wildbads zu Abach in nieder Bayrn. C. Fischer, Regensburg, Germany, 106 pp.

- (1702) Balnei Abacensis in Bavaria inferior nova descriptio. Das ist: Kurze Beschreibung des Wildbads zu Abach in nieder Bayrn. J.C. Haam, Straubing, Germany, 87 pp.

- (1718) Balnei Abacensis in Bavaria inferior nova descriptio. Das ist: Kurze Beschreibung des Wildbads zu Abach in nieder Bayrn. J.B. Lang, Regensburg, Germany, 106 pp.

Leitmeier H. (1938) Smaragdbergbau und Smaragdgewinnung in Österreich. Berg- und Hüttenmännische Monatshefte, Vol. 86, No. $1 / 2$, pp. 3-12.

Lenzen G. (1966) Produktions- und Handelsgeschichte des Diamanten. Duncker \& Humblot, Berlin, 280 pp.

Leuthold C.E. (1887) Das Österreichische Bergrecht in seinen Grundzügen dargestellt. Prague and Leipzig, F. Tempsky and G. Freytag, 278 pp.

Lewandowski K. (1997) Der Smaragdbergbau in der Leckbachrinne im Habachtal. Museumsverein Heimatmuseum, Bergbauforschung, Bramberg, Austria, 23 pp.

- (2008) Der "vergessene" Bergbau im Oberpinzgau. Berichte der Geologischen Bundesanstalt, Vol. 72, pp. 47-58.

Lipold M.V. (1863) Über das Vorkommen von Smaragden im Habachthale des Ober-Pinzgaues im Salzburgischen. Jahrbuch der k.k. geologischen Reichsanstalt, Vol. 13, No. 4, pp. 147148.

Lorenz J.R. (1857) Vergleichende orographisch-hydrographische Untersuchung der Versumpfungen in den oberen Flussthälern der Salzach, der Enns und der Mur, oder im Pinzgau, Pongau, und Lungau. Sitzungsberichte der mathematisch-naturwissenschaftlichen Classe der kaiserlichen Akademie der Wissenschaften, Vol. 26, No. 1, pp. 91-151.

MacAlister D.A. (1900) The emerald mines of northern Etbai. The Geographical Journal, Vol. 16, No. 5, pp. 537-549.

Manger R. (1857) Das Oesterreichische Bergrecht nach dem allgemeinen Berggesetze für das Kaiserthum Oesterreich vom 23. Mai 1854. F.A. Credner, Prague, 339 pp.

M.INST.M.M. [Member of the Institution of Mining and Metallurgy, London] (1908) Precious stones and gems. The Mining Journal, Vol. 83, pp. 189-190.

Mitchell R.K. (1984) Further light on the Sancy diamond. Journal of Gemmology, Vol. 19, No. 2, pp. 144-146.

Mohs F. (1804) Jac. Fried von der Null Mineralien-Kabinet. Erste Abteilung. Auf Kosten des Besitzers und in Commission der Camesinaischen Buchhandlung, Vienna, 330 pp.

Niedermayr G. (1988) Mineralien und Smaragdbergbau im Habachtal. Doris Bode Verlag GmbH, Haltern, Germany, 48 pp.

(2003) Mineralien, Geologie und Smaragdbergbau im Habachtal/Pinzgau. Bode Verlag GmbH, Haltern, Germany, 96 pp.

Panzer A. (1961) Amethyst und Achat vom Schlüsselstein/Vogesen. Der Aufschluss, Vol. 12, No. 1, p. 3.

Pech H. (1976) Smaragde - Gauner und Phantasten. Pinguin-Verlag, Innsbruck, Austria, 123 pp. 
Peters K. (1854) Die geologischen Verhältnisse des Oberpinzgaues, insbesondere der Centralalpen. Jahrbuch der k.k. geologischen Reichsanstalt, Vol. 5, No. 4, pp. 766-808.

Peters K.F. (1862) Herr Karl F. Peters an Herrn G. Rose. Zeitschrift der Deutschen geologischen Gesellschaft, Vol. 14, No. 2, pp. 248-250 [letter dated May 10].

_ (1867) Aus meinen Erinnerungen an den Pinzgau. Österreichische Revue, Vol. 5, No. 7, pp. 139-156.

Pichler G.A. (1865) Salzburg's Landes-Geschichte. Verlag der Oberer'schen Buchhandlung, Salzburg, Austria, 1076 pp.

Pillwein B. (1839) Das Herzogthum Salzburg oder der Salzburger Kreis. Joh. Christ. Quandt, Linz, Austria, 554 pp.

Präsidialbureau des k. k. Finanzministeriums (1917) Nachweis ausländischer, im Inland eine Filiale besitzender Aktiengesellschaften. Mitteilungen des k. k. Finanzministeriums, Vol. 22, pp. 38-40.

Redl A. (1813) Handlungs Gremien und Fabricken Adressen Buch von Wien und NiederOestreich für das Jahr 1813. Publ. by the author, Vienna, $439 \mathrm{pp}$.

Reif H. (1908) Sammlung von Entscheidungen der k.k. Gerichtsund Verwaltungsbehörden in Bergbauangelegenheiten, I. Administrativer Teil. Manzschen k. u. k. Hof-Verlags- und Universitäts-Buchhandlung, Vienna, pp. 24-26.

Reisigl F.A. (1786) Topographisch-historische Beschreibung des Oberpinzgaus im Erzstifte Salzburg. Waisenhausbuchhandl., Salzburg, Austria, 116 pp.

Reuß F.A. (1801) Lehrbuch der Mineralogie: nach des Herrn O.B.R. Karsten mineralogischen Tabellen. Zweiten Theiles Erster Band der Oryktognosie. Friedrich Gotthold Jacobäer, Leipzig, $466 \mathrm{pp}$.

Ritter von Köchel L. (1859) Die Mineralien des Herzogthumes Salzburg. Carl Gerold's Sohn, Vienna, 160 pp.

Ritter von Zepharovich V. (1859) Mineralogisches Lexicon für das Kaiserthum Osterreich. I. Band. Wilhelm Braumüller, Vienna, p. 57

(1869) Mineralogische Notizen. Jahrbuch der k.k. geologischen Reichsanstalt, Vol. 19, No. 2, pp. 225-234.

Rivard J.-L., Foster B.C., Sidebotham S.E. (2002) Emerald city. Archaeology, Vol. 55, No. 3, pp. 36-41.

Rohr C. (2007) Extreme Naturereignisse im Ostalpenraum. Naturerfahrung im Spätmittelalter und am Beginn der Neuzeit. Böhlau Verlag, Cologne, 640 pp.

Rolshoven M. (2009) Salzburgisches Fürsterzbischöfliches Kabinett und die mineralogisch-petrographischen Sammlungen des Benediktinerstifts St. Peter zu Salzburg. Jahrbuch der Geologischen Bundesanstalt, Vol. 149, No. 2+3, pp. 325-330.

Russegger J. (1835) Über den Bau der Centralalpenkette im Herzogthume Salzburg. Zeitschrift für Physik und verwandte Wissenschaften, Vol. 3, No. 3, pp. 248-282.

Schaup W. (2000) Salzburg auf alten Landkarten 1551-1866/67. Stadtgemeinde, Salzburg, Austria, 395 pp.

Scherz G. (1952) Nicolai Stenonis epistolae et epistolae ad eum datae. Tomus Prior. Hafniae, Nyt Nordisk Forlag, Arnold Busck, 480 pp.

(1955) Niels Stensens Smaragdreise. Centaurus, Vol. 4, No. 1 , pp. $51-57$

(1956) Vom Wege Niels Stensens. Beiträge zu seiner naturwissenschaftlichen Entwicklung. Acta Historica Scientiarum Naturalium et Medicinalium, Vol. 14, pp. 128-137, 141-215.

- (1958) Nicolaus Steno and his Indice. Acta Historica Scientiarum Naturalium et Medicinalium, Vol. 15, pp. 189-275.

- (1971) Niels Stensens Reisen. Acta Historica Scientiarum Naturalium et Medicinalium, Vol. 23, pp. 9-139.

- (1987) Niels Stensen: Eine Biographie, Band I, 1638-1677. St. Benno-Verlag GmbH, Leipzig, 376 pp. [For an English translation see Kardel and Maquet, 2013]

Schlüter W. (1938) Osterreichisches Bergrecht. Glückauf. Berg- und Hüttenmännische Zeitschrift, Vol. 74, No. 24, pp. 519-526.
Schoen H. (1939) Vorbehaltene Mineralien in Großdeutschland. Montanistische Rundschau, Vol. 31, No. 7, pp. 200-204.

Schroll C.M.B. (1792) Geographisch-mineralogische Uebersicht der Salzburgischen Berg- und Hüttenwerke. In Briefen an einen seiner Freunde. Abhandlungen einer Privatgesellschaft von Naturforschern und Oekonomen, Vol. 1, pp. 261-307.

(1799) Geographisch-mineralogische Uebersicht der Salzburgischen Berg- und Hüttenwerke. In Briefen an einen seiner Freunde. Jahrbücher der Berg- und Hüttenkunde, Vol. 3, pp. 53-73.

Schroll K.M. (1797) Grundriss einer Salzburgischen Mineralogie. Jahrbücher der Berg- und Hüttenkunde, Vol. 1, pp. 95-196.

Seemann R., Koller F., Grundmann G., Brandstätter F., Steininger H. (1990) Historische Kupferlagerstätte "Hochfeld" und Epidot-Fundstelle "Knappenwand", Untersulzbachtal. Mitteilungen der Österreichischen Mineralogischen Gesellschaft, Vol. 135 , pp. 95-117.

Seemann R., Koller F., Höck V. (1993) Die Mineralfundstelle Knappenwand - Erweiterte Zusammenfassung. Abhandlungen der Geologischen Bundesanstalt, Vol. 49, pp. 33-37.

Seifriedsberger J. (2007) Das Bramberger Blei-, Gold- und Silberrevier. Bramberger Montanhefte, Vol. 6, $92 \mathrm{p}$.

- (2008) Bergbau in Hollersbach - vom 16. zum 19. Jahrhundert. Bramberger Montanhefte, Vol. 7, 74 p.

Semrád P. (2012) Opal Kings: Genealogy of the Family Goldschmidt von Libanka. Granit Ltd., Prague, 16 pp.

- (2015) European precious opal from Cervenica-Dubník an historical and gemmological summary. Australian Gem mologist, Vol. 25, No. 11-12, pp. 372-388.

Shaw I., Bunbury J., Jameson R. (1999) Emerald mining in Roman and Byzantine Egypt. Journal of Roman Archaeology, Vol. 12, pp. 203-215, http://dx.doi.org/10.1017/S1047759400017980

Sinkankas J. (1981) Emerald and Other Beryls. Chilton Book Company, Radnor, Pennsylvania, 665 pp.

Skinner W.R. (1892) The Mining Manual for 1891-2. Walter R. Skinner, London, p. 433, 524, 675.

(1899) The Mining Manual for 1899. Walter R. Skinner, London, p. 864.

(1907) The Mining Manual for 1907. Walter R. Skinner, London, p. 839.

- (1910) The Mining Manual for 1910. Walter R. Skinner London, p. 747.

(1922) The Mining Manual and Mining Year Book for 1922 p. 203.

Sobiech F. (2008) Niels Stensen (1638-1686) und der Bergbau. Seine Reise durch Tirol, Niederungarn, Böhmen und Mitteldeutschland 1669-1670 im Spiegel seiner Theologie. In W. Ingenhaeff and J. Bair, Eds., 6. Internationaler Montanhistorischer Kongress Schwaz 2007, pp. 287-304.

Spencer L.J. (1911) The larger diamonds of South Africa. Mineralogical Magazine and Journal of the Mineralogical Society, Vol. 16, No. 74, pp. 140-148, http://dx.doi.org/10.1180/minmag.1911.016.74.11

Stamm F. (1855) Das Österreichische allgemeine Berggesetz vom 23. Mai 1854. Karl André, Prague, 269 pp.

Stehrer S. (2000) Rätsel um Smaragd geklärt. Salzburger Nachrichten, Vol. 56, April 11, 2000, p. 11.

Sterrett D.B. (1907) Emerald. Austria. Mineral Resources of the United States. Calendar Year 1906. United States Geological Survey, Washington D.C., p. 1215.

Stiny J. (1938) Über die Regelmäßigkeit der Wiederkehr von Rutschungen, Bergstürzen und Hochwasserschäden in Österreich. Geologie und Bauwesen, Vol. 10, No. 1, pp. 9-31, 33-48.

Streeter E.W. (1903) Egyptian gold and gem syndicate, limited. The Economist, Vol. 61, No. 3116, p. 891.

Thompson A. (1906a) Emerald mines of Austria. The Engineering and Mining Journal, Vol. 82, No. 6, p. 267.

- (1906b) Emerald mines of Austria. The Mining Journal, Railway and Commercial Gazette, Vol. 79, p. 857. 
Trautwein T. (1870) Wegweiser durch Südbaiern, Nord- und Mittel-Tirol und angrenzende Theile von Salzburg und Kärnten. 3rd Edition, Verlag der J. Lindauer'schen Buchhandlung, Munich, p. 71.

Treptow L. (1899) Das Habachtal und seine Berge. Mittheilungen des Deutschen und Österreichischen Alpenvereins, Vol. 25, No. 9, pp. 105-108, and No. 10, pp. 117-121.

Tschermak G. (1874) Neue Einsendungen an das k.k. mineralogische Hofmuseum. Verhandlungen der k.k. geologischen Reichsanstalt, Vol. 1874, No. 4, pp. 86-87.

Viernstein M. (1987) Geschichte des Flußspatbergbaus in Bayern. Geologica Bavarica, Vol. 91, pp. 95-100.

Vierthaler F.M. (1816) Meine Wanderungen durch Salzburg, Berchtesgaden und Österreich, Zweiter Theil. Carl Gerold, Vienna, $280 \mathrm{pp}$.

Voltz (1828) Ueberblick der Mineralien der beiden Rhein-Departemente. In J.F. Aufschlager, Das Elsass. Neue historischtopographische Beschreibung der beiden Rhein-Departemente. Friedrich Carl Heitz, Strasbourg, France, pp. 1-10.

Von Arx R. (1984) John Taylor \& Sons in Switzerland. In British Mining No. 25, Memoirs 1984. Northern Mine Research Society, Sheffield, England, 5 pp.

Von Gränzenstein G. (1855) Das allgemeine österreichische Berggesetz vom 23. Mai 1854 und die Verordnungen über die Bergwerksabgaben vom 4. October 1854. Friedrich Manz, Vienna, $463 \mathrm{pp}$.
Von Kürsinger I. (1841) Ober-Pinzgau, oder: der Bezirk Mittersill. Eine geschichtlich, topographisch, statistisch, naturhistorische Skizze. Oberer'sche lithographisch-typographische Anstalt, Salzburg, Austria, 288 pp.

Von Petersen M. (1816) Brief aus Regensburg vom 20. Nov. 1815. Taschenbuch für die gesammte Mineralogie mit Hinsicht auf die neuesten Entdeckungen, Vol. 10, pp. 591-593.

Von Rosenfeld L. (1863) Vereinsnachrichten für den Monat Juli und August 1863. Verhandlungen und Mittheilungen des siebenbürgischen Vereins für Naturwissenschaften, Vol. 14, No. 8, pp. 129-130.

Wallmann H. (1870) Das Habach-Thal. Jahrbuch des Österreichischen Alpenvereins, Vol. 6, pp. 95-105.

Ward F. (1993) Emeralds. Gem Book Publishers, Bethesda, Maryland, $64 \mathrm{pp}$.

Weinschenk E. (1891) Ganggestein aus dem Habachtal, Oberpinzgau. Tschermak's Mineralogische und Petrographische Mitteilungen, Vol. 12, No. 4, pp. 328-331.

(1896) Die Minerallagerstätten des Gross-Venedigerstockes in den Hohen Tauern. Zeitschrift für Krystallographie und Mineralogie, Vol. 26, No. 1-6, pp. 337-508

Zappe J.R. (1817) Alphabetische Aufstellung und Beschreibung alles bisher bekannten Fossilien. Zweite Auflage, zweiter Band. Carl Ferdinand Beck, Vienna, 327 pp.

Zirkl E.J. (1982) Niels Stensen (Nicolaus Steno) im Habachtal. Die Eisenblüte N.F., Vol. 3, No. 6, p. 20.

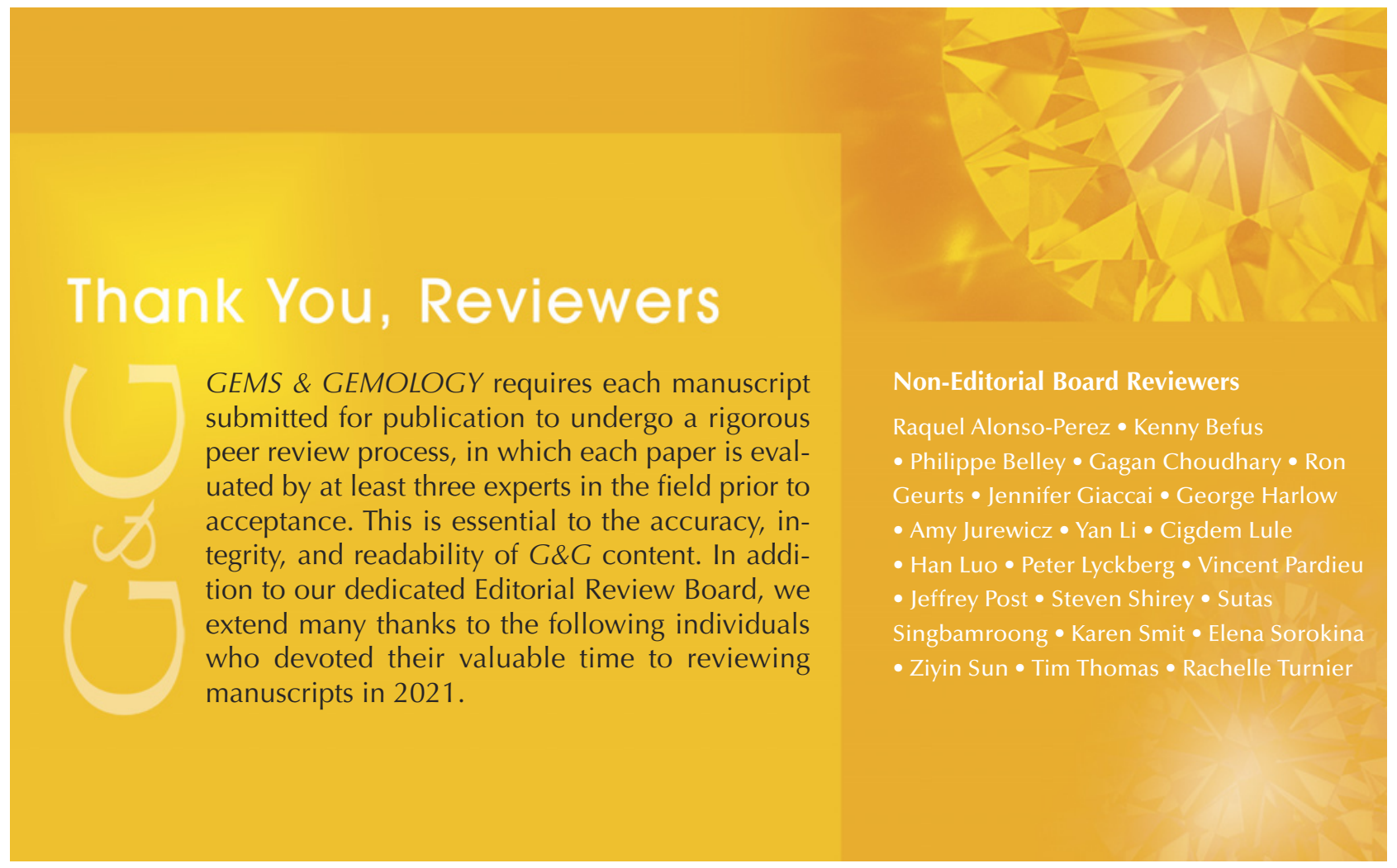

